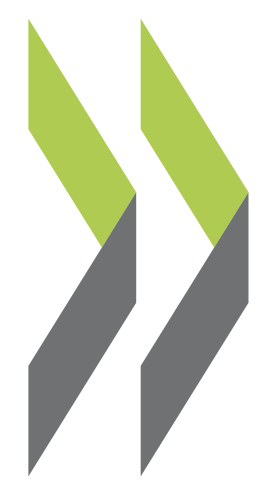

OECD Economics Department Working Papers No. 1549

Reducing regional disparities for inclusive growth in Spain
Müge Adalet McGowan, Juan Antona San Millán 


\section{REDUCING REGIONAL DISPARITIES FOR INCLUSIVE GROWTH IN SPAIN} ECONOMICS DEPARTMENT WORKING PAPERS No. 1549

\section{By Müge Adalet McGowan and Juan Antona San Millán}

OECD Working Papers should not be reported as representing the official views of the OECD or of its member countries. The opinions expressed and arguments employed are those of the author(s).

Authorised for publication by Isabell Koske, Deputy Director, Country Studies Branch, Economics Department.

All Economics Department Working Papers are available at www.oecd.org/eco/workingpapers.

JT03447513 
OECD Working Papers should not be reported as representing the official views of the OECD or of its member countries. The opinions expressed and arguments employed are those of the author(s).

Working Papers describe preliminary results or research in progress by the author(s) and are published to stimulate discussion on a broad range of issues on which the OECD works.

Comments on Working Papers are welcomed, and may be sent to OECD Economics Department, 2 rue André Pascal, 75775 Paris Cedex 16, France, or by e-mail to eco.contact@oecd.org.

All Economics Department Working Papers are available at www.oecd.org/eco/workingpapers.

This document and any map included herein are without prejudice to the status of or sovereignty over any territory, to the delimitation of international frontiers and boundaries and to the name of any territory, city or area.

The statistical data for Israel are supplied by and under the responsibility of the relevant Israeli authorities. The use of such data by the OECD is without prejudice to the status of the Golan Heights, East Jerusalem and Israeli settlements in the West Bank under the terms of international law.

On 25 May 2018, the OECD Council invited Colombia to become a Member. At the time of preparation the deposit of Colombia's instrument of accession to the OECD Convention was pending and therefore Colombia does not appear in the list of OECD Members and is not included in the OECD zone aggregates.

\section{(c) OECD (2019)}

You can copy, download or print OECD content for your own use, and you can include excerpts from OECD publications, databases and multimedia products in your own documents, presentations, blogs, websites and teaching materials, provided that suitable acknowledgment of OECD as source and copyright owner is given. All requests for commercial use and translation rights should be submitted to rights@oecd.org 


\section{ABSTRACT/RÉSUMÉ \\ Reducing regional disparities for inclusive growth in Spain}

Spain is a highly decentralised country, making the effective implementation of national reforms dependent on regional policies. Some regional disparities are high and need to be reduced. High regional dispersion in education and job outcomes, compounded by low inter-regional mobility, emerge as key drivers of regional inequalities in income and wellbeing. Lifelong learning programmes that take into account regional specific needs would help foster regional skills and attract firms to lagging regions. Ensuring full portability of social and housing benefits across regions, by providing temporary assistance either by the region of origin or the central government, would improve inter-regional mobility. At the same time, barriers to achieving a truly single market limit productivity growth of regions, including the most advanced. Reducing regulatory barriers and better innovation policies would boost productivity. Effective intergovernmental coordination bodies and a welldesigned interregional fiscal equalisation system will be key to ensuring that regions have the incentives to implement policies for inclusive growth.

This Working Paper relates to the 2018 OECD Economic Survey of Spain (http://www.oecd.org/eco/surveys/economic-survey-spain.htm).

JEL classification: D24; E24; I24; J24; J61; J65; O31

Keywords: Spain, regions, education, labour markets, productivity, labour mobility, housing markets, lifelong learning, fiscal decentralisation, innovation

\section{Réduire les disparités régionales pour une croissance inclusive en Espagne}

L'Espagne étant un État fortement décentralisé, la mise en œuvre efficace des réformes nationales est tributaire des politiques publiques régionales. Certaines disparités régionales sont prononcées et doivent être atténuées. La forte dispersion régionale des résultats en termes d'éducation et d'emploi, que la faiblesse de la mobilité interrégionale ne fait d'accentuer, apparaît comme le principal déterminant des inégalités régionales de revenu et de bien-être. Des programmes de formation tout au long de la vie, qui prendraient en considération les besoins spécifiques de chaque région, aideraient au développement régional des compétences et attireraient les entreprises vers les régions moins avancées. La transférabilité intégrale, d'une région à l'autre, des droits aux prestations sociales et aux aides au logement, grâce à la mise en place d'une assistance temporaire qui serait assurée soit par la région d'origine, soit par l'État espagnol, aurait pour effet d'améliorer la mobilité interrégionale. Par ailleurs, les obstacles à l'achèvement d'un marché véritablement unique brident la croissance de la productivité dans les régions, même dans les plus développées. La réduction des obstacles réglementaires et de meilleures politiques d'innovation seraient porteuses de gains de productivité. Enfin, une coordination efficace entre les différentes administrations et un système de péréquation budgétaire bien pensé seraient des facteurs essentiels pour inciter les régions à mettre en œuvre des politiques publiques propices à une croissance inclusive.

Ce document de travail prend appui sur l'Étude économique de l'Espagne 2018, publiée par l'OCDE (http://www.oecd.org/fr/eco/etudes/etude-economique-espagne.htm).

Classification JEL: D24; E24; I24; J24; J61; J65; O31

Mots-clés : Espagne, régions, éducation, marchés du travail, productivité, mobilité de la main-d'œuvre, marchés du logement, formation tout au long de la vie, décentralisation budgétaire, innovation 


\section{Table of contents}

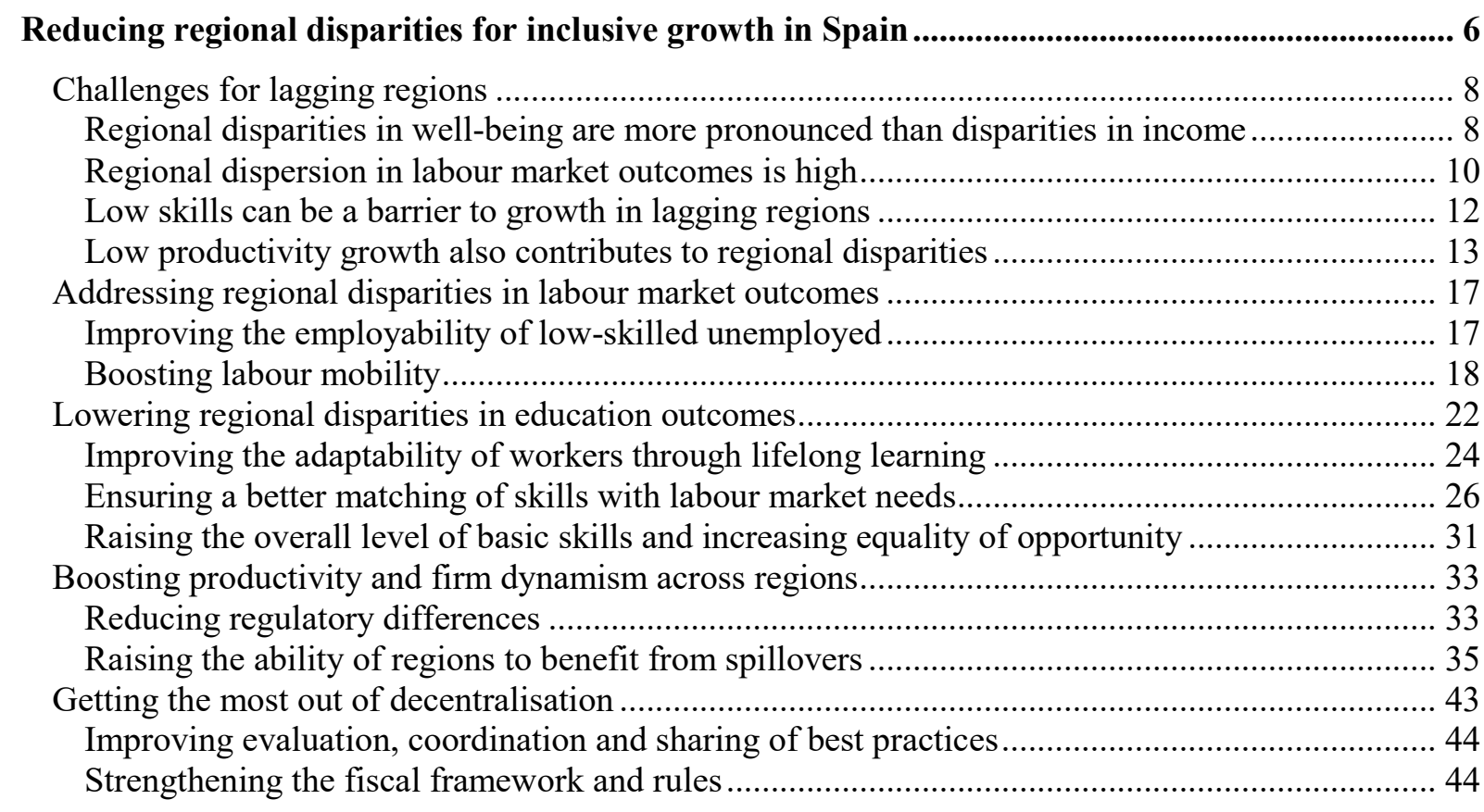

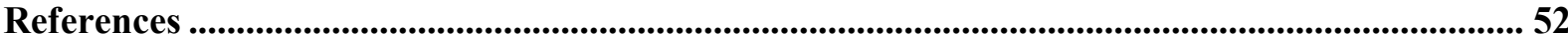

\section{Tables}

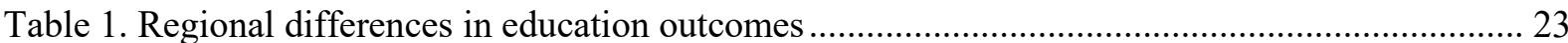

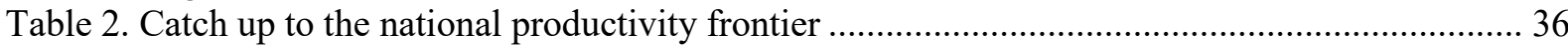

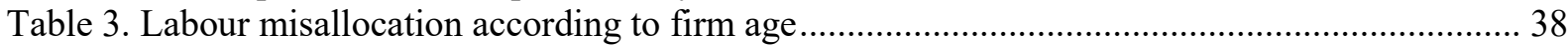

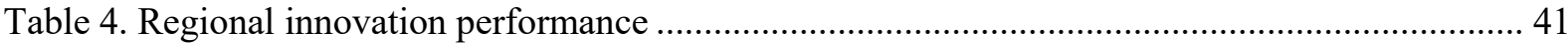

\section{Figures}

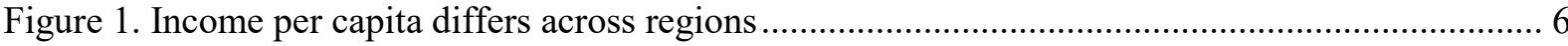

Figure 2. Per capita income growth has become stronger in richer regions than in poorer ones ........... 7

Figure 3. Regional disparities in income and poverty are high .......................................................... 9

Figure 4. Regional disparities may have implications for well-being at the country level ................... 10

Figure 5. The dispersion of unemployment rates across regions is relatively high.............................. 11

Figure 6. Low levels of education are associated with high unemployment rates at the regional level.

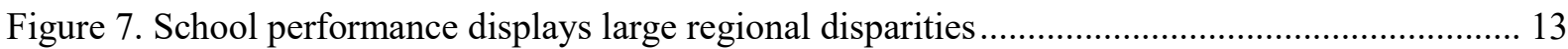

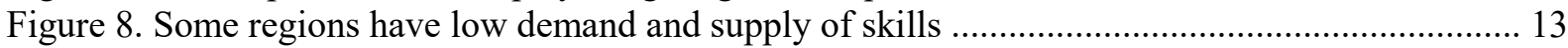

Figure 9. Labour productivity is also a driver of regional disparities ................................................... 14

Figure 10. There is much scope to boost the productivity of Spanish frontier firms ............................ 15

Figure 11. Investment in intangible assets is low in most regions .................................................... 16

Figure 12. Regional differences in terms of the percentage of high productivity firms are high .......... 16

Figure 13. Within-country dispersion in business survival rates....................................................... 17 


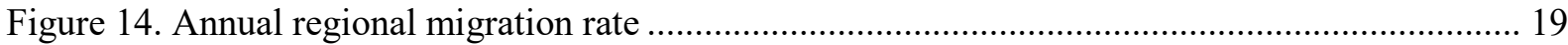

Figure 15. Burden of housing costs, especially for tenants and low-income households, is high........ 21

Figure 16. Potential gains to productivity from policy reforms that reduce skill mismatch ................ 23

Figure 17. Participation in life-long learning across Europe by educational attainment....................... 25

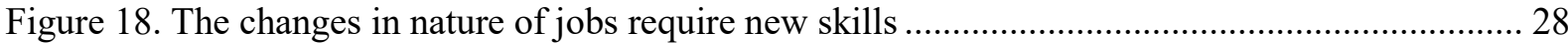

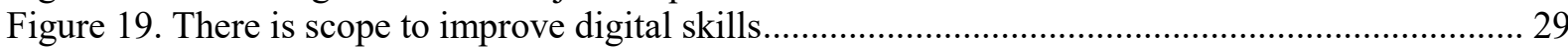

Figure 20. Spanish firms lag in their use of key digital technologies............................................... 30

Figure 21. Grade repetition and early school leaving rates are positively related at the regional

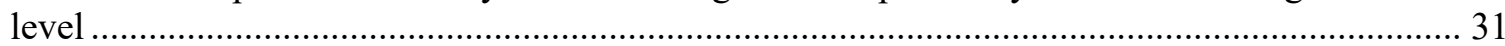

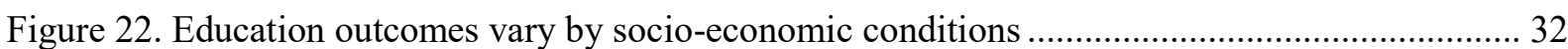

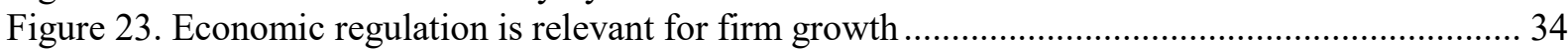

Figure 24. Barriers to starting a business and business birth rates at the regional level....................... 35

Figure 25. Factors and policies to boost spillovers from the frontier.................................................. 37

Figure 26. Resource misallocation is heterogeneous across Spanish regions ........................................ 39

Figure 27. The share of jobs with high-performance workplace practices is low ................................. 40

Figure 28. Regions have different strengths in terms of exposure to international factors ................... 43

Figure 29. Distribution of expenditures and revenues across levels of government ............................ 45

Figure 30. Responsibilities of regional governments are large in some areas...................................... 46

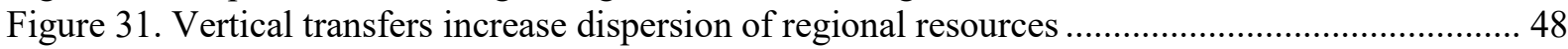

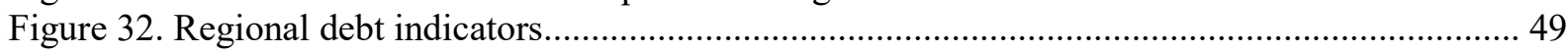

\section{Boxes}

Box 1. Responsibilities across different levels of government............................................................ 7

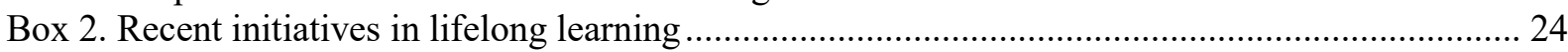

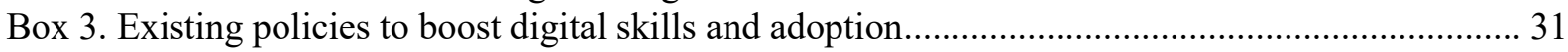

Box 4. Achieving good education outcomes: the case of Castille-Leon ............................................... 33

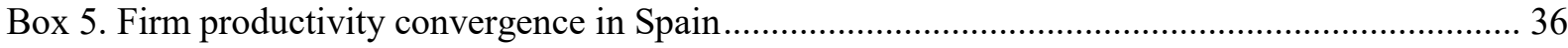

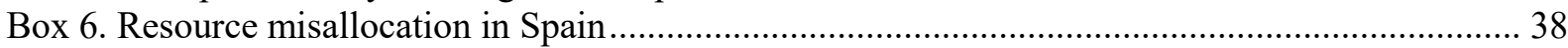

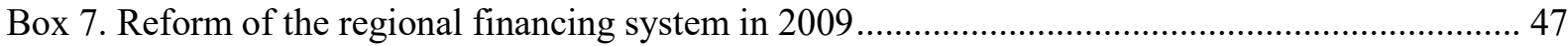

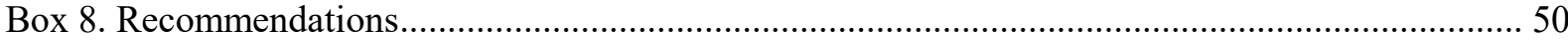




\title{
Reducing regional disparities for inclusive growth in Spain
}

\author{
By Müge Adalet McGowan and Juan Antona San Millán ${ }^{1}$
}

Ensuring the benefits of growth are spread widely requires a strong focus on greater convergence of regions in terms of income and well-being. There is some evidence that the gap in per capita income across regions has slightly narrowed in the last three decades in Spain (Puente, 2017). Nevertheless, GDP per capita in the best performing region was around double that in the worst performing region in 2016 (Figure 1). Furthermore, the Great Recession has contributed to the slowing down of regional convergence in terms of GDP per capita in OECD countries in general, but especially those hit hard by the crisis (OECD, 2018a). Regions were catching up between 2000 and 2007, but this was reversed during the crisis in Spain (Figure 2). While this trend was partly cyclical and is slowly improving, persistent regional differences in a number of dimensions beyond income remain.

Figure 1. Income per capita differs across regions

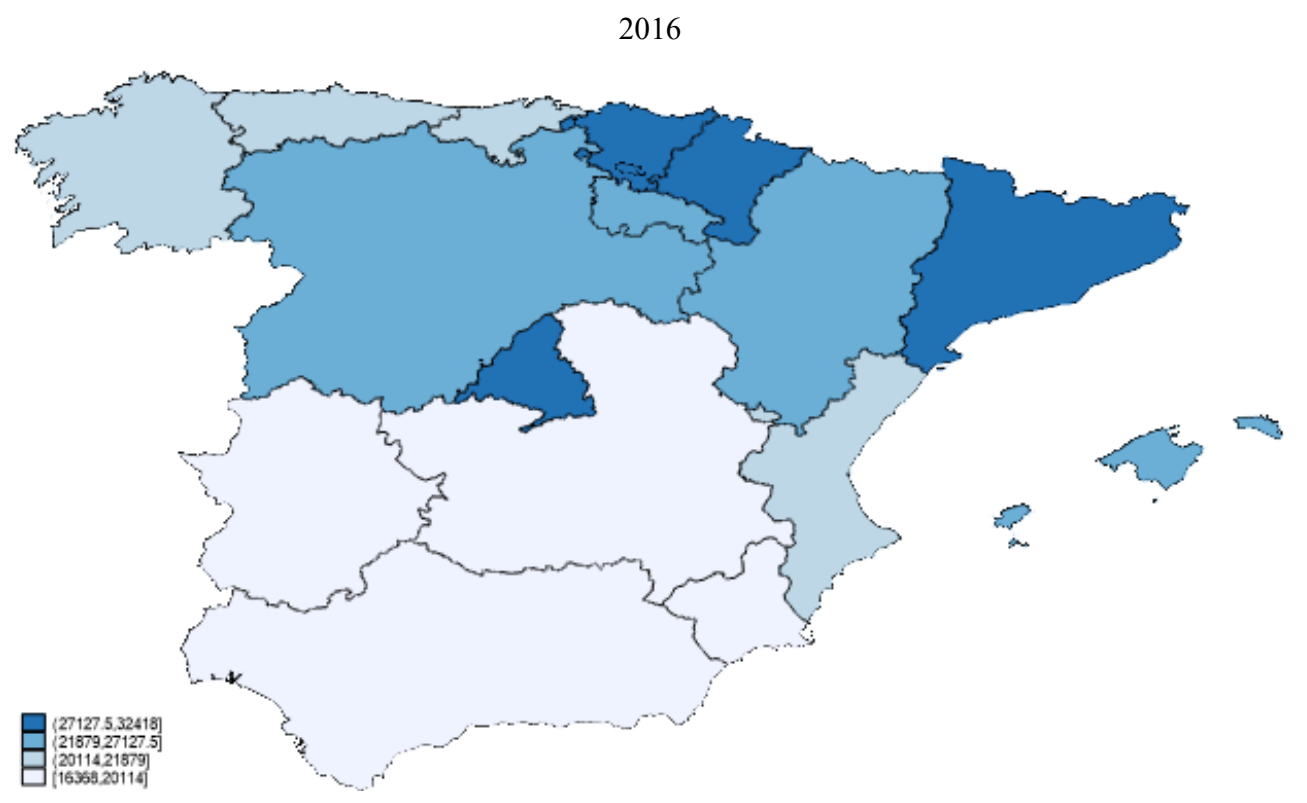

Note: A darker shade corresponds to a higher value.

Source: OECD (2018), Regional Economy Statistics.

1. Müge Adalet McGowan is from the Economics Department and Juan Antona San Millán was on secondment from the Ministry of Economy and Business to the OECD Economics Department at the time of writing this paper. The authors would like to thank Pierre Beynet, Aida Caldera Sanchez, Peter Gal, Isabel Koske, David Law and Álvaro Pereira from the Economics Department, and colleagues from the Directorate for Employment, Labour and Social Affairs, the Directorate for Education and Skills, and the Centre for Entrepreneurship, SMEs, Regions and Cities for helpful comments on this paper. The authors would also like to thank Paula Adamczyk for statistical assistance and Poeli Bojorquez and Sylvie Ricordeau for editorial assistance. 
Spain is one of the most highly decentralised countries in the OECD with regards to public spending and many public services are provided at the regional level (Box 1). Furthermore, the timely and effective implementation of national reforms will depend on regional policies and institutions.

This paper assesses regional disparities in a number of dimensions and discusses policies at the national and regional level to enhance the productive and employment capacities of lagging regions.

Figure 2. Per capita income growth has become stronger in richer regions than in poorer ones

Average annual growth of the GDP per capita gap between the richest 20\% and the poorest $20 \%$ of TL 3 regions, percentage

4

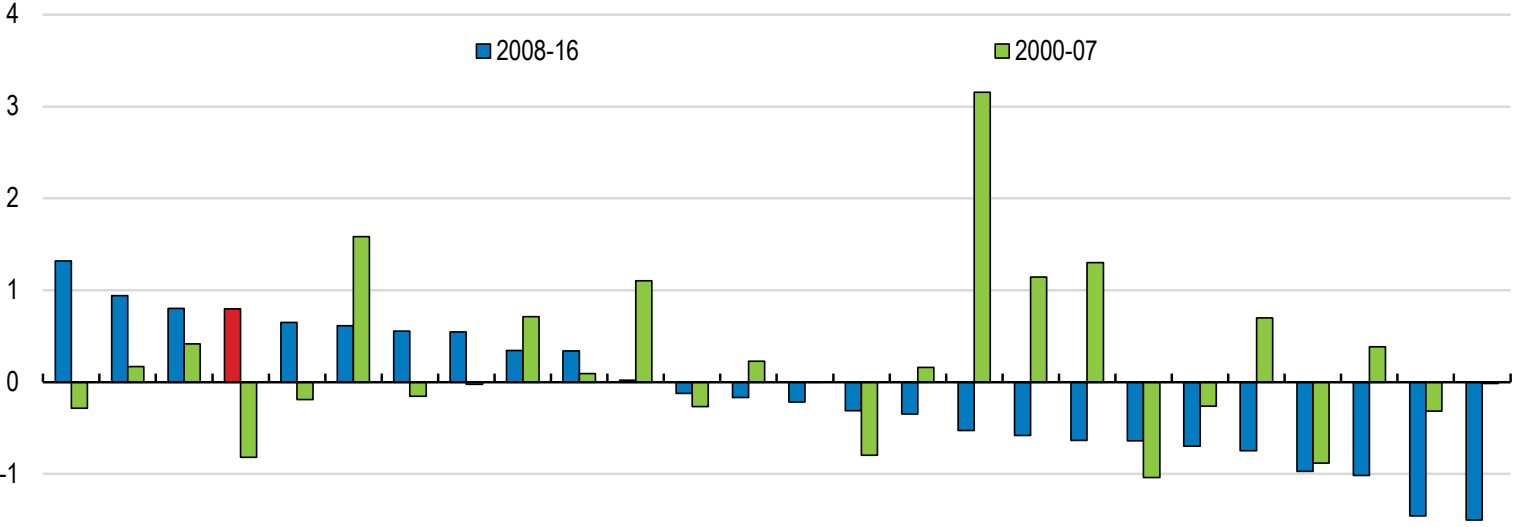

$-2$

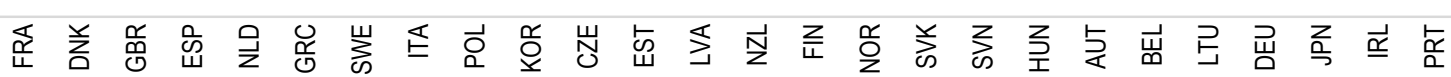

Source: OECD (2018), Regional Economy Statistics.

\section{Box 1. Responsibilities across different levels of government}

Spain has a three-tier system with central, regional and local governments. There are 17 self-governing autonomous regions, 2 autonomous cities, 50 provinces and more than 8119 municipalities. The map of competences is regulated in the Spanish Constitution and while some are exclusively managed by the central government, most of them are shared between the central and regional governments. Specifically, the central government passes basic legislation and regions regulate and implement their own laws. As a general rule, all responsibilities not expressly attributed to the central state can be devolved to regions. Some of the policies covered in this paper have the following distribution of competences:

- The central government designs the legislative framework for unemployment benefits and establishes general objectives of active labour market policies (ALMPs) at the national level. Regions implement and develop ALMPs, while the central government administers and funds the unemployment benefit system.

- Social security allowances, including pensions, and contributions paid by workers and firms are the responsibility of the central government. 
- Education is a shared competence, with the central government defining the overall structure of the education system and other general elements such as the requirements for teachers. Meanwhile, regions enjoy a high degree of budgetary and organisational autonomy. For example, they decide on teachers' salaries, the creation of new schools, the budget for schools and its allocation among schools, and the placement of principals and teachers.

- The long-term care legal framework is defined by the central government, but it has budgetary dependence on regions.

- Minimum income benefits and social inclusion policies are under the responsibility of regions, but they are implemented by local authorities.

- Health is a shared competence, with the central government defining the main framework in national laws, but leaving the provision of the public service and the regulation of key aspects, such as human resources or number of centres, to regions.

- The main goals of housing policy are defined in a multi-annual plan by the central government, but regions and local entities establish priorities and define requirements for entitlements. For example, regions and local governments decide the number of social houses, the allocation of funding, and the requirements to privatise social housing services and to track users of social housing.

- Research is a shared competence, with the central government responsible for promotion and general coordination and the regions setting up their own R\&D policies and instruments.

\section{Challenges for lagging regions}

\section{Regional disparities in well-being are more pronounced than disparities in income}

Making growth more inclusive remains a challenge in Spain (OECD, 2017a). A regional breakdown suggests that disparities are relatively high in terms of inequality and poverty rates. The inter-regional difference of the relative poverty rates ( $60 \%$ of the median income) between the lowest and highest regions in Spain at 25\% is large (Figure, Panel A). The Gini coefficient across regions also varies from 0.05 to 0.26 . According to another measure of regional disparities, controlling for the average level of the Gini coefficient, interregional differences in income inequality are also relatively high (Figure, Panel B). 
Figure 3. Regional disparities in income and poverty are high
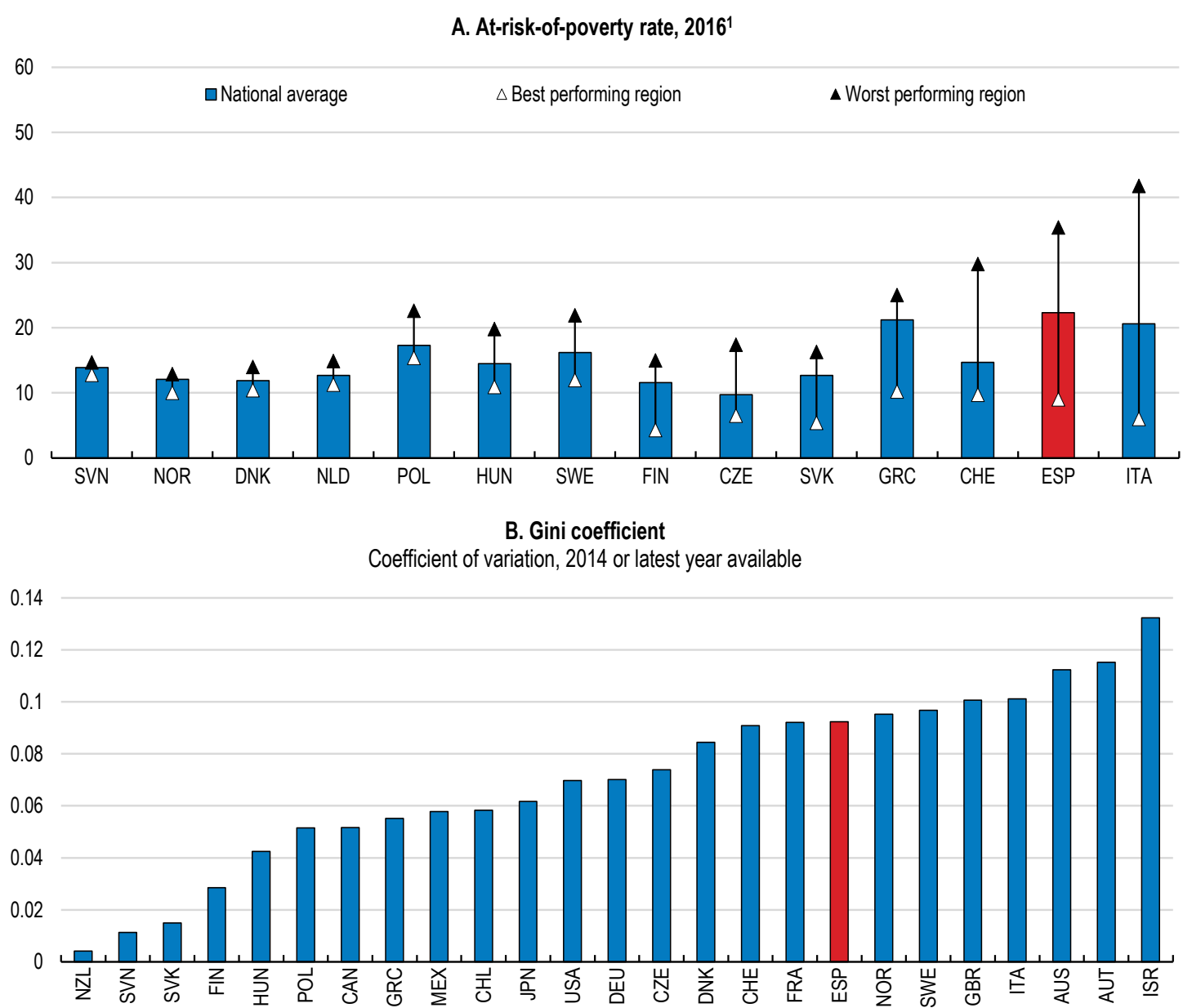

1. At-risk-of-poverty rate is defined as the share of people with an equivalised disposable income below the risk-of-poverty threshold, which is set at $60 \%$ of the national median equivalised disposable income.

2. The Gini coefficient is calculated for household disposable income after taxes and transfers, adjusted for differences in household size. The coefficient of variation is defined as the ratio of standard deviation to the mean.

Source: Eurostat and OECD, Regional Well-being Database.

Higher regional disparities in a number of dimensions may be linked to lower well-being scores overall at the country level on average across OECD countries (OECD, 2014). Compared to other OECD countries, the regional disparities in Spain are especially important in terms of jobs and education (Figure ). These are areas where Spain also ranks relatively low at the country level in international comparison, which motivates the focus of the paper on labour market and education policies. 
Figure 4. Regional disparities may have implications for well-being at the country level

2017 or latest year available

A. Education

Share of workforce with at least secondary education Average scores

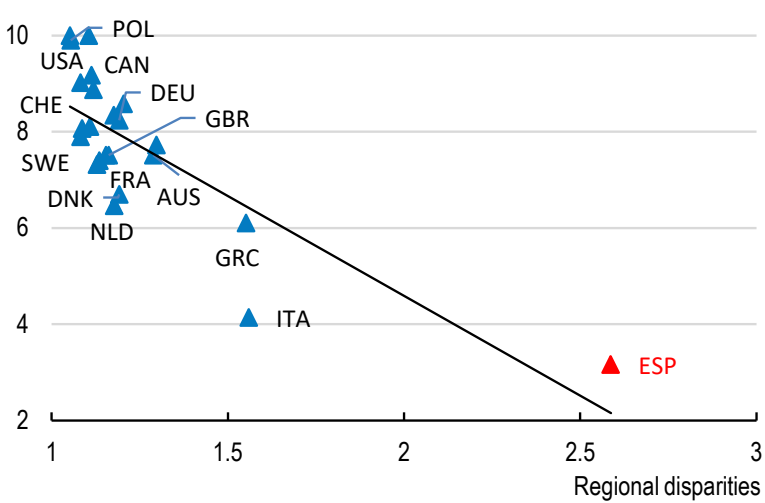

B. Jobs

Unemployment and employment rate

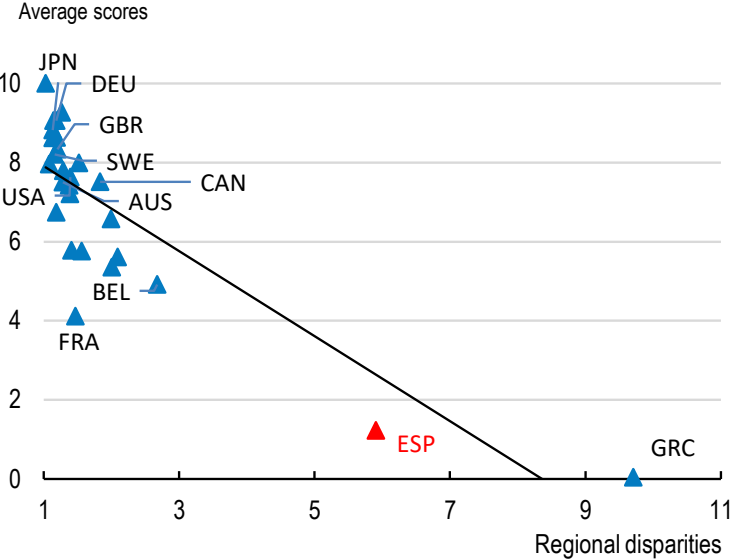

Note: The regional disparities scores on the $\mathrm{x}$ axis are computed as the score of the top $20 \%$ of regions divided by the scores of the bottom $20 \%$, where a higher score refers to higher disparities. The average scores on the $y$ axis are average country values for education and jobs, scaled to a score between 1 and 10, where higher values indicate a higher share of workforce with at least secondary education in Panel A and a combination of employment and unemployment rates in Panel B.

Source: OECD, Regional Well-being Database.

\section{Regional dispersion in labour market outcomes is high}

Regional dispersion in unemployment rates, as measured by the gap between unemployment rates in the best and worst performing regions, is the third highest in the OECD (Figure, Panel A). Regional disparities in youth unemployment rates and the share of youth that is neither employed nor in education and training (NEET) are also high (Figure, Panels B and C). Improving the labour market outcomes of the youth will require effective policies that will increase the flexibility of labour markets, via higher decentralisation of collective agreements and internal flexibility of firms. Policies to improve their skills and educational attainment will also be key, as high rates of youth NEET are related to a large number of dropouts in compulsory education. 
Figure 5. The dispersion of unemployment rates across regions is relatively high

A. Unemployment rate

Percentage of labour force aged 15-64, 2017

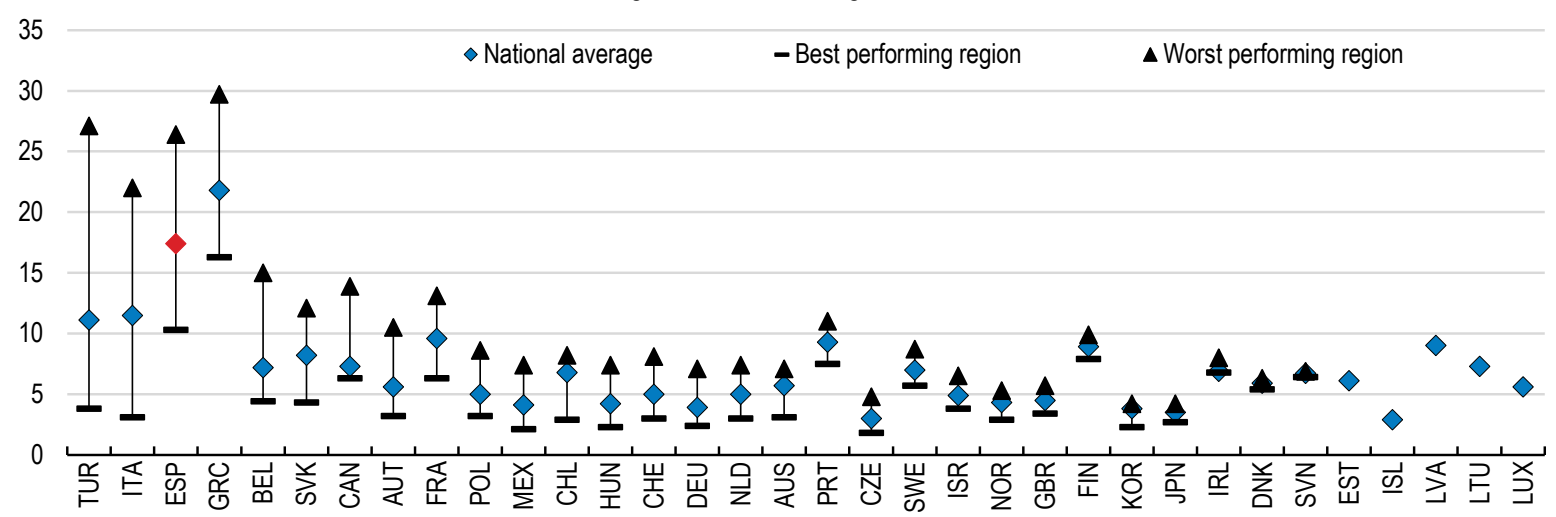

B. Youth unemployment

Percentage of labour force aged 15-24, 2017

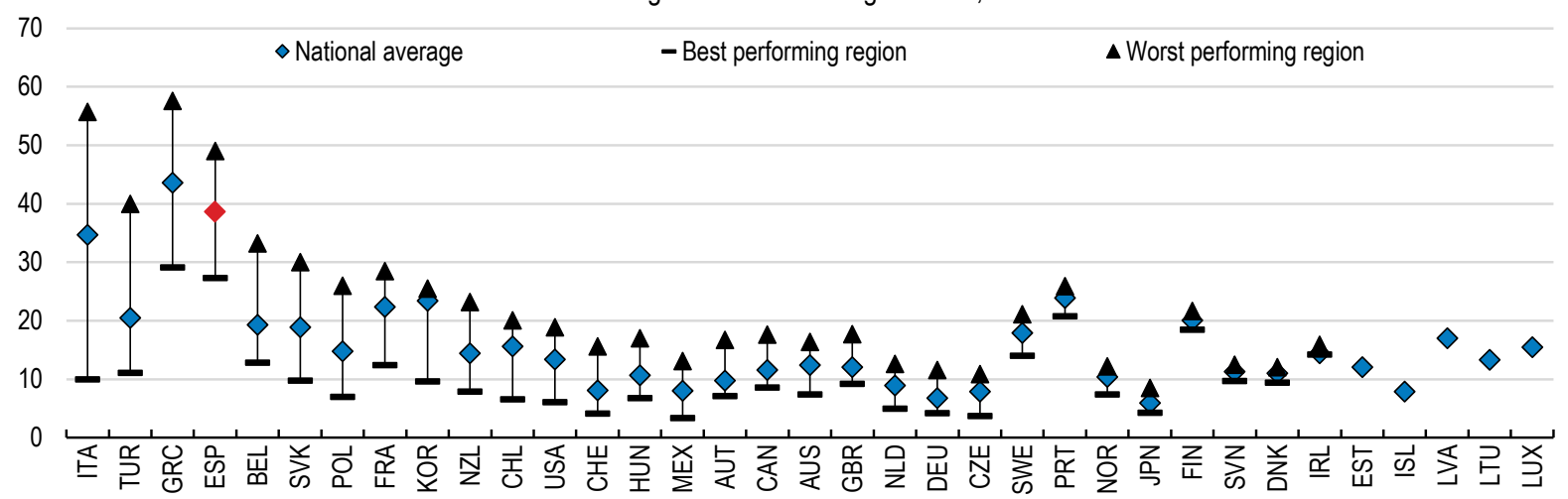

C. Young people neither in employment nor education and training Percentage of the population aged 18-24, 2017

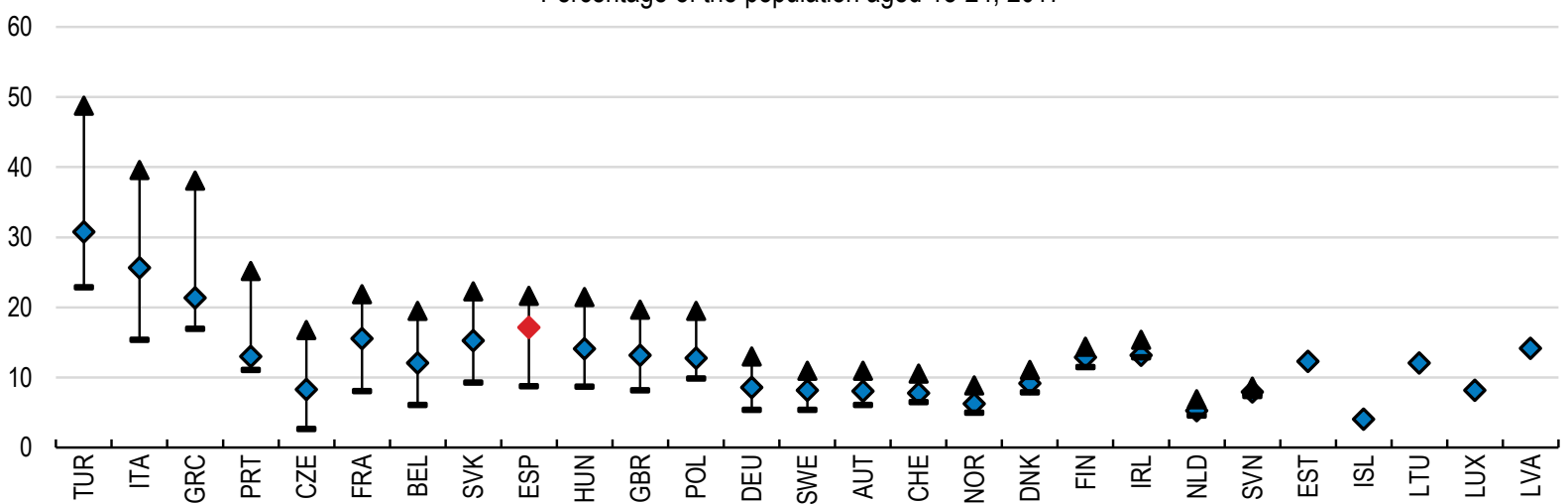

Note: Countries are ranked according to the range of differences between regions.

Source: OECD, Regional Statistics Database and Eurostat.

Higher educational attainment and skills can lead to better employment prospects and wages (OECD, 2017a). In Spain, the gap between the unemployment rate of those with tertiary education and less than upper secondary education at around $14 \%$ is higher than the EU average of $10 \%$. There is also a positive relationship between unemployment rates 
and the share of the labour force with less than secondary education at the regional level (Figure ). The relationship between qualification and skills and employment becomes even more important in a world economy changing by globalisation and digitalisation, highlighting the need for policies to upskill the labour force via policies such as lifelong learning.

Figure 6. Low levels of education are associated with high unemployment rates at the regional level

Unemployment rate

30

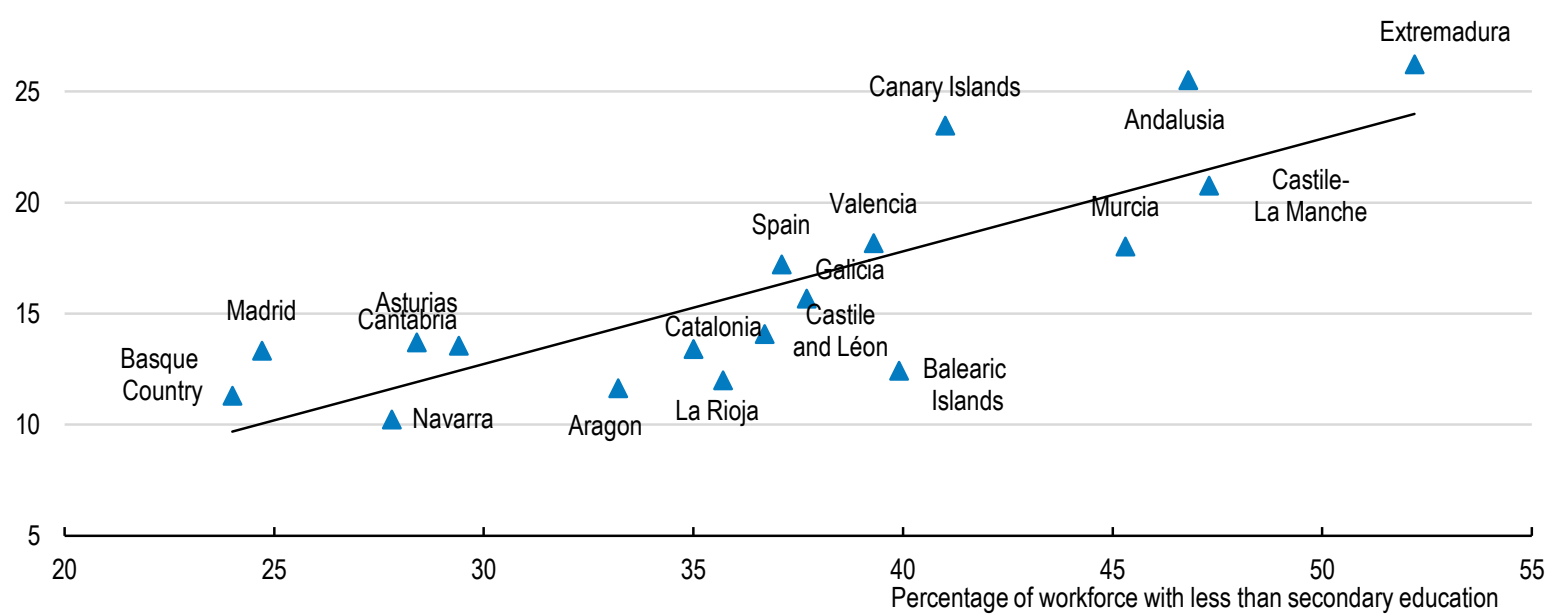

Source: INE (2018), Labour market statistics, September.

\section{Low skills can be a barrier to growth in lagging regions}

While there has been an increase in educational attainment over the past two decades across regions, regions differ considerably in their ability to develop a skilled labour force. For example, the mean mathematics score according to PISA shows that while best performing regions in Spain are close to the performance in best performing OECD countries, the worst performing regions perform close to the worst performing OECD countries (Figure). Furthermore, the impact of socio-economic background on education outcomes is significantly different across regions.

As skills and jobs become increasingly globalised and digitalised, some regions can be left behind as workers and firms become concentrated in fewer places. While such a concentration can bring agglomeration benefits, it can also have adverse effects of increasing regional inequalities. Comparing the supply of skills (the percentage of people with post-secondary education) and the level of skills demanded for local jobs (the share of medium and high-skilled occupations) shows that there is a high demand and supply of skills, i.e. a high skills equilibrium, in some regions, while both the demand and the supply of skills are low in a number of regions (Figure ) (OECD, 2016a). 
Figure 7. School performance displays large regional disparities

Mean PISA scores in mathematics, 2015

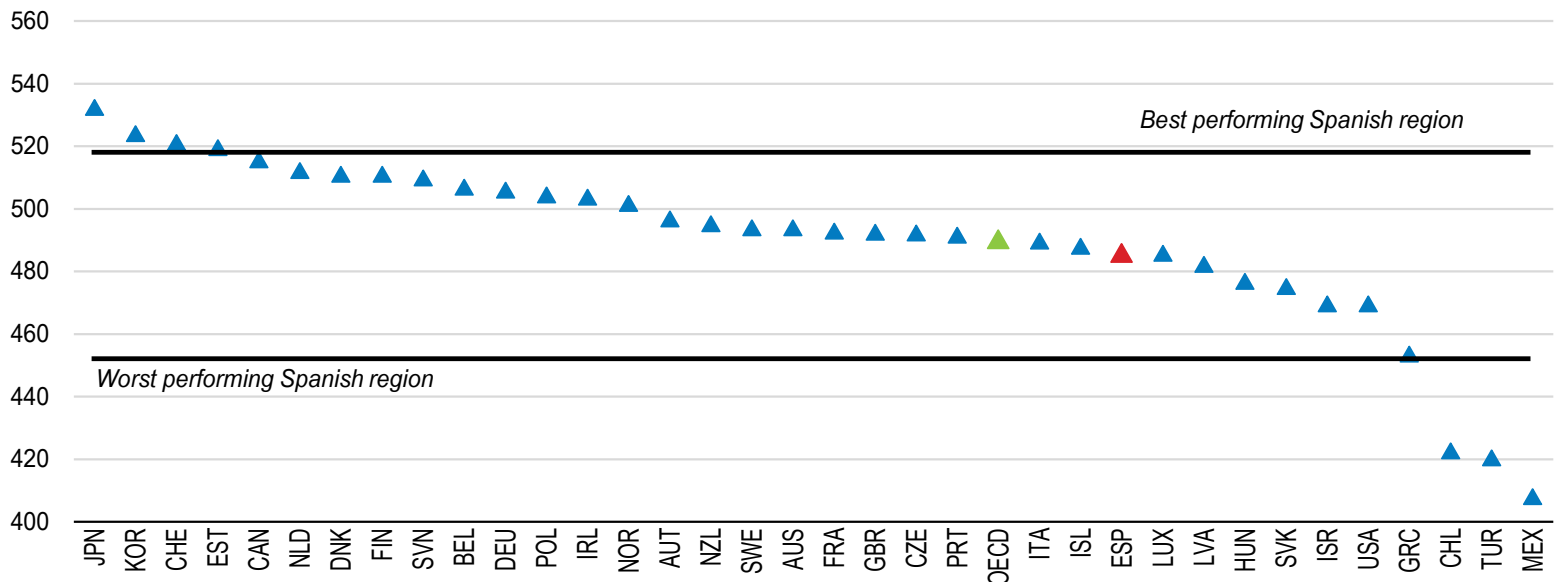

Source: OECD (2016), PISA 2015 Results (Volume I): Excellence and Equity in Education.

Figure 8. Some regions have low demand and supply of skills

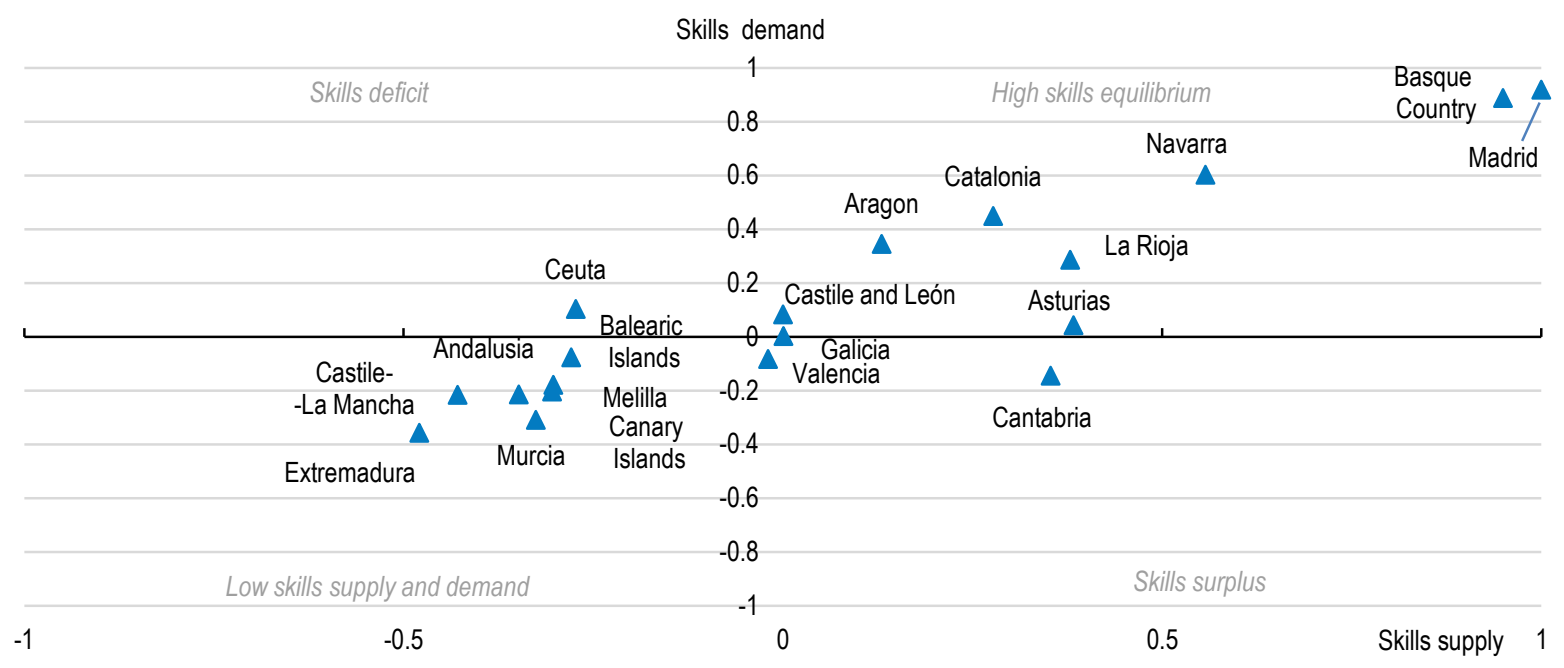

Note: The level of skills supply is the percentage of people with post-secondary education. The demand for skills is a composite index combining the percentage of the population holding medium- and high-skilled occupations (International Standard Classification of Occupations categories 1,2,3,6 and 7) and productivity (GVA per worker). See (OECD, 2016a) for more details.

Source: OECD (2016), Job Creation and Local Economic Development.

In regions with low levels of skill supply and demand, there may be less incentive to invest in upgrading skills, given the scarcity of high-skilled jobs. At the same time, firms may have little incentive to move to higher-skilled production and services, knowing that the local workforce does not have the level of skills required to fill these types of jobs, contributing to low productivity. Hence, boosting growth in lagging regions will depend on both higher firm productivity and worker skills.

\section{Low productivity growth also contributes to regional disparities}

Decomposing changes in GDP per capita into changes in labour productivity and the participation rate suggests that productivity is the main driver of regional inequalities in 
many OECD countries (Blöchliger, Bartolini and Stossberg, 2016). Indeed, across the OECD, the gap within countries between the top $10 \%$ regions with the highest labour productivity and the bottom $75 \%$ has grown on average by almost $60 \%$ over the last two decades (OECD, 2016b and 2016c). In Spain, regional disparities are equally driven both by productivity and employment (Figure ). Most of the reduction in regional differences in labour productivity has been driven by capital accumulation, while there is a lack of convergence in multifactor productivity (MFP) (Puente, 2017; Mas, Pérez and Quesada, 2009).

Figure 9. Labour productivity is also a driver of regional disparities

Coefficient of variation of each factor, contribution to total variation

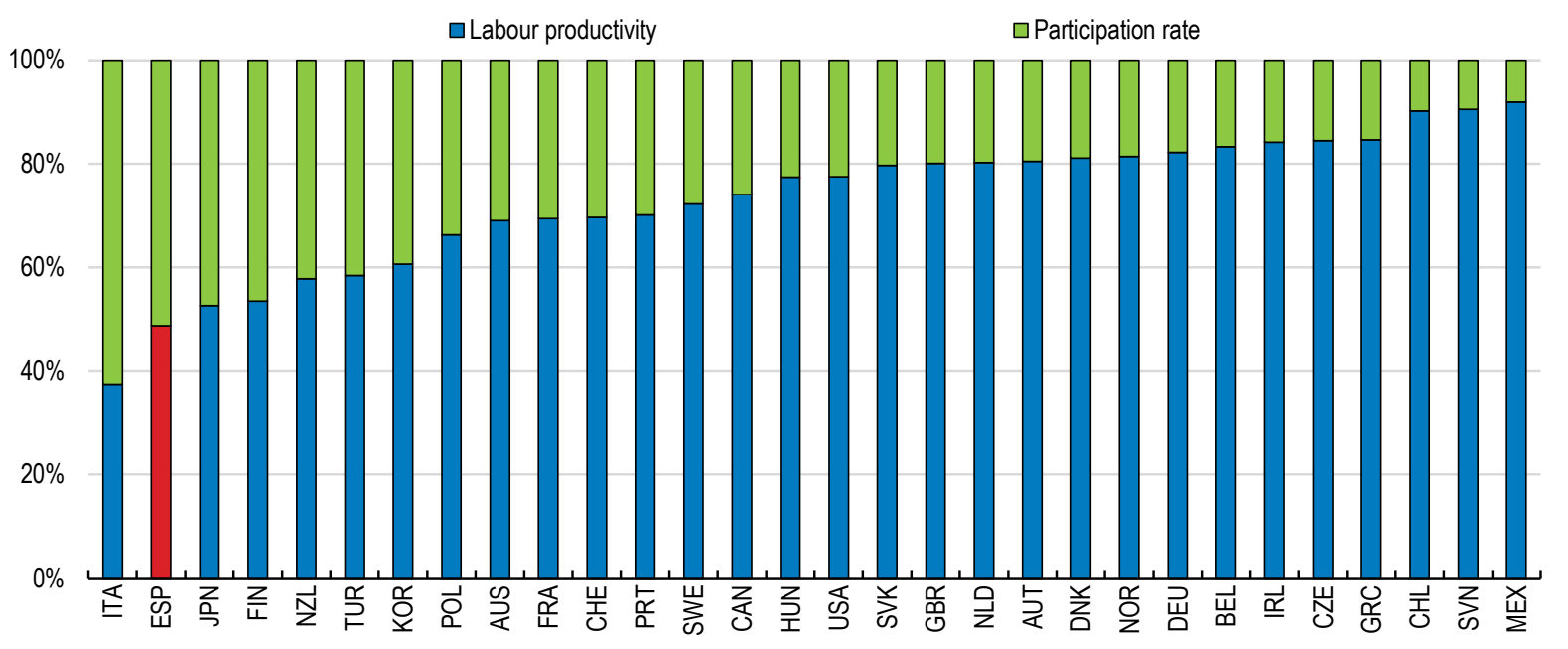

Note: The variation of regional GDP per capita is decomposed into the contributions of labour productivity (GDP per worker), and participation rate, which includes labour resource utilisation (those employed as a share of the active working population) and the activity rate (per cent of the active working population in total population).

Source: Estimates based on OECD (2016), "Regional economy", OECD Regional Statistics (database); Blöchliger et al., 2016.

\section{Barriers to economies of scale can hold back productivity growth of regions and firms}

While labour productivity dispersion across regions is relatively low in international perspective, the catch-up of lagging regions to the rest masks a problem of low dynamism of Spain's best performing (frontier) regions (OECD, 2018a). There is a need to improve the dynamism of frontier regions, which might be better equipped to reap the benefits of new technologies and agglomeration effects. At the same time, in order to reduce regional disparities, policies to facilitate the diffusion of technologies from national best performing firms and regions to laggards will be key (OECD, 2015). In this context, gaps in infrastructure and weak links between urban and rural areas, which is an important barrier to reducing regional disparities in many countries, is less of an issue in Spain, where institutional barriers are more important.

The fact that frontier regions are not dynamic in Spain can be partly explained by the relatively low productivity performance of best-performing (frontier) Spanish national firms, whose productivity gap with the global frontier firms remains high (Figure ). This could partly be a reflection of regional regulatory differences and misallocation of resources, which prevent the most productive firms from growing in size, expanding across 
regions and reaping the benefits of economies of scale. At the same time, the productivity performance of Spanish frontier and laggard firms has been similar, especially in the manufacturing sector, reflecting that lagging firms in Spain tend to converge to the productivity levels of best performing national firms (Law, 2018).

Figure 10. There is much scope to boost the productivity of Spanish frontier firms

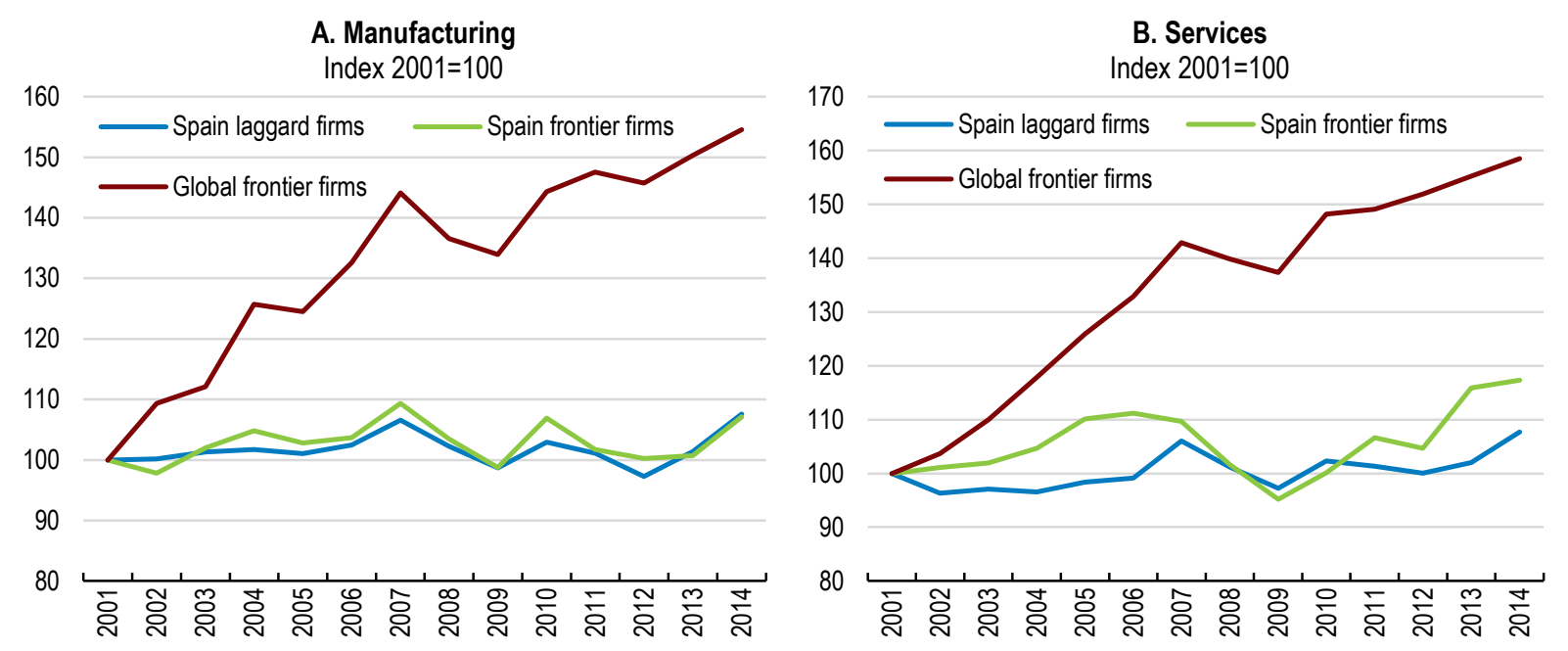

Note: The frontier is defined as the top $5 \%$ most productive firms for each 2-digit industry and year, based on value-added labour productivity.

Source: OECD calculations based on ORBIS. See (Andrews, Criscuolo and Gal, 2016) for further details on methodology.

\section{Lack of an environment conducive to productivity growth in lagging regions}

Regions in Spain differ in their relative strengths and initial conditions, which can already be linked to existing differences in labour productivity, suggesting that regions with worse initial conditions could converge to best practices. For example, investment in intangible capital as a share of GDP, which has been linked to productivity growth (Andrews and Criscuolo, 2013; Siedschlag, Lawless and Ubaldo, 2017), is higher in regions with a higher share of frontier firms (Figure and Figure, Panel A). In turn, regions with a higher share of frontier firms tend to be those with the highest regional productivity performance (Figure, Panel B). These links and the persistence of the regional shares of high productivity firms over time suggest that regional characteristics may be a factor in determining firm performance and productivity. 
Figure 11. Investment in intangible assets is low in most regions

Share of GDP, 2013

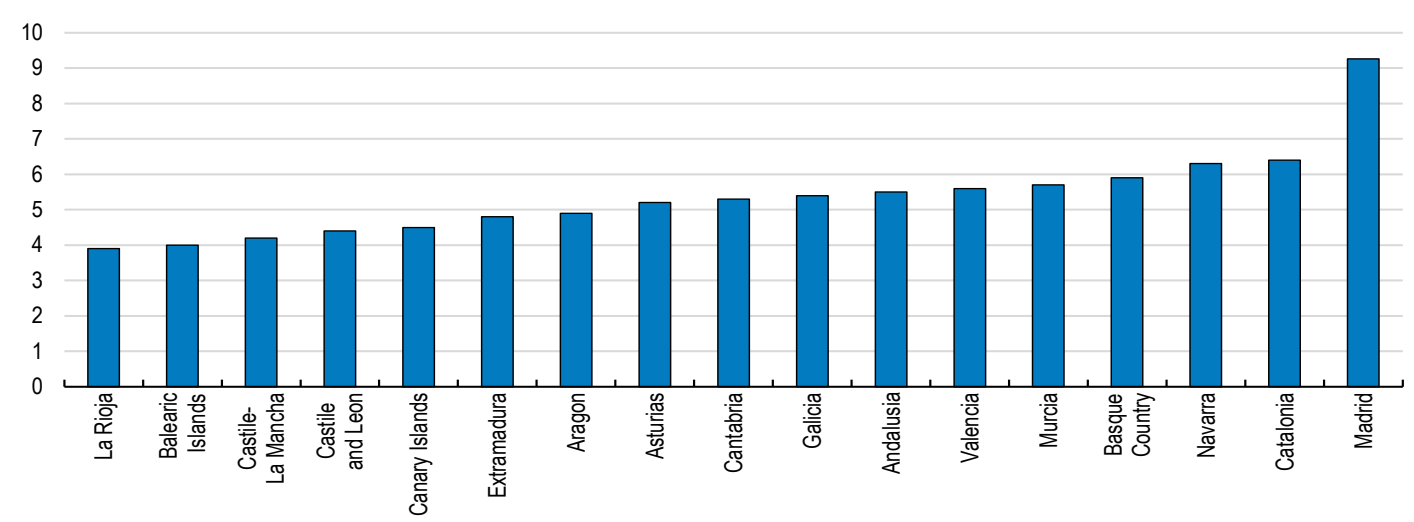

Source: Cotec Foundation for Innovation-Ivie, Intangible assets: database for Spain and its autonomous communities (1995-2014), April 2017. Database available at: http://informecotec.es/activos-intangibles/.

Figure 12. Regional differences in terms of the percentage of high productivity firms are high A. The number of national frontier firms as a percentage of all firms in a region, 2014

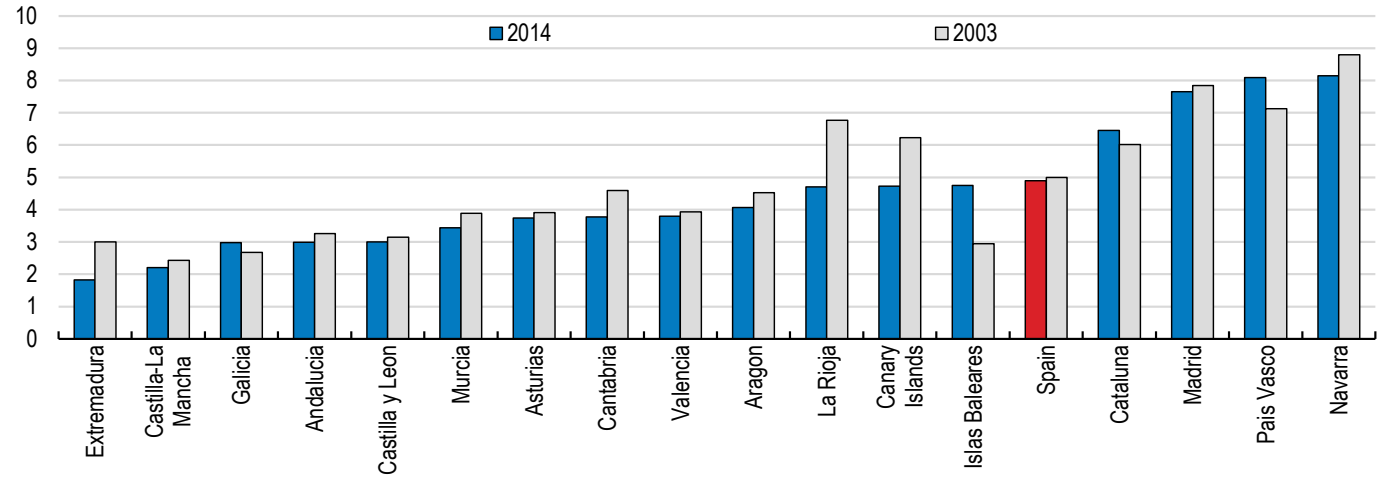

B. A higher share of frontier firms is associated with higher productivity, 2014

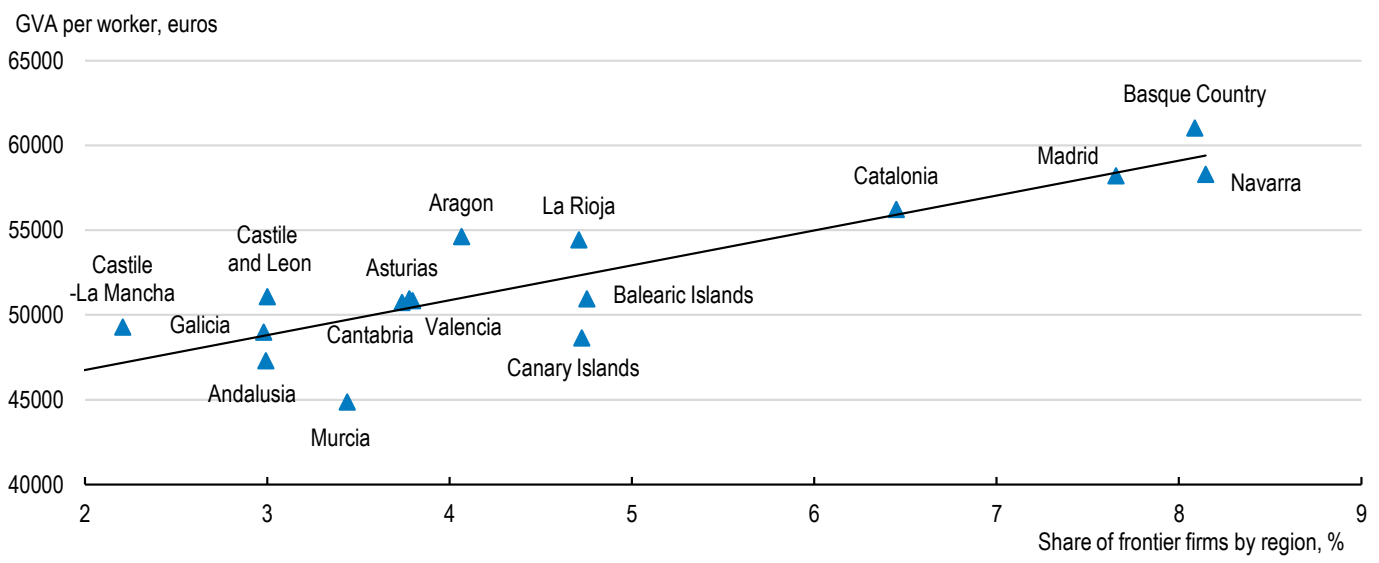

Note: The frontier is defined as the top 5\% most productive firms for each 2-digit industry and year, based on value-added labour productivity.

Source: OECD calculations based on ORBIS. 
The location of entrepreneurial activity depends on regional characteristics such as costs and access to services and skilled labour (Fritsch, 2008). Spain is one of the countries with the highest regional dispersion in terms of firm birth and death rates as well as employment creation by enterprise births (OECD, 2017b). Spain also displays a high degree of interregional dispersion in firm survival rates, defined as three years after firm birth. For example, the best-performing region in Spain, the Basque Country, experienced the same survival rate of $65 \%$ as the best-performing region amongst the OECD regions for which data are available (Figure), while the ratio was $45 \%$ in the worst-performing region in Spain. The wide within-country variation suggests that the conditions for firms to become more productive are not evenly distributed across regions.

Figure 13. Within-country dispersion in business survival rates

TL2 regions, 2014 (or last available year), percentage

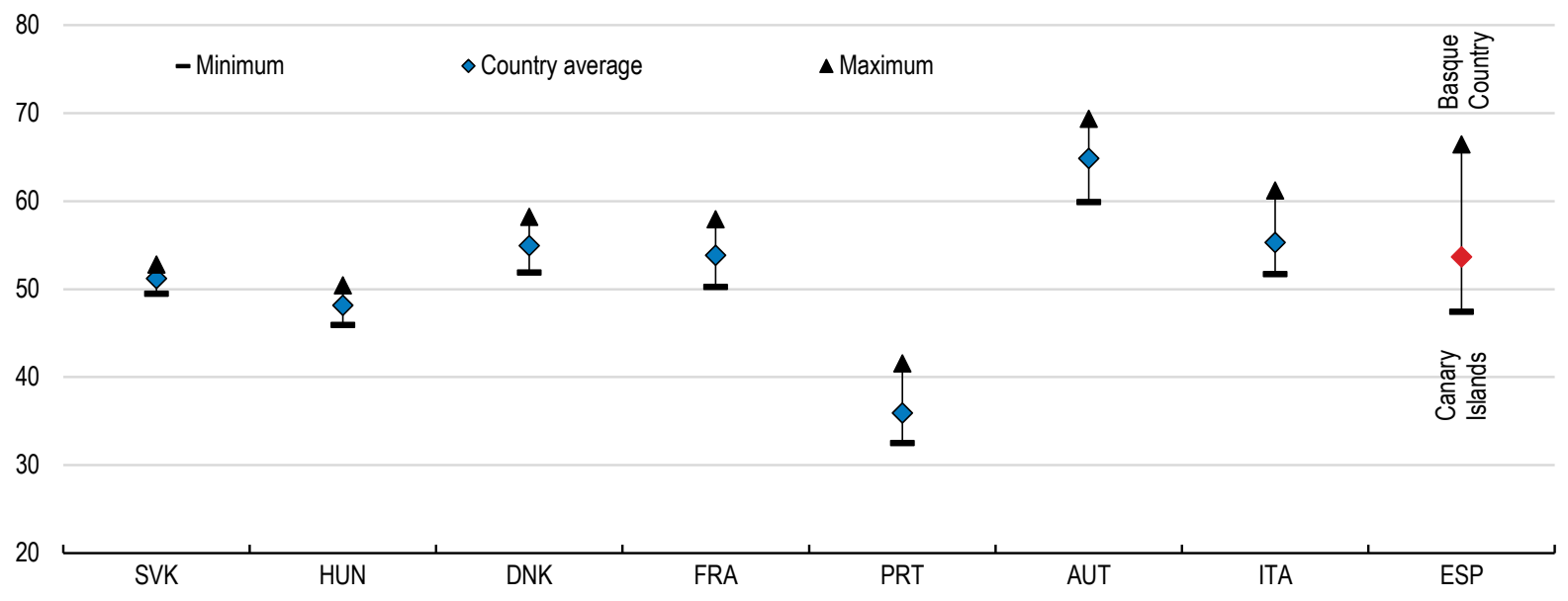

Note: Survival rates measure the number of firms created in year $\mathrm{t}-3$ which are still active at time $\mathrm{t}$ (three-year survivors/births t-3). 2014 or last available year. Countries are ranked according to the range of difference between regions in the survival rates of all firms.

Source: OECD (2018), Regional Business Demography Database.

\section{Addressing regional disparities in labour market outcomes}

\section{Improving the employability of low-skilled unemployed}

The provision of active labour market policies (ALMPs) is the responsibility of regions, while the central government establishes general objectives of ALMPs at the national level. Hence coordination and information sharing is paramount to their success. Recent initiatives, such as Programa de Aprendizaje Mutuo, which aim to share best practices across regions, are limited, but a step in the right direction. The overall resources of public employment services are well below that in other OECD countries and staff-to-job seeker ratios are low. Increasing the efficiency of public employment services by higher staff-tojob seeker ratios and better specialisation of counsellors, as recommended in the 2017 Economic Survey of Spain, would improve the effectiveness of ALMPs. Making these policies effective requires an efficient allocation of funding across regions.

Regional differences in unemployment rates have put pressure on the resources of regional public employment services in an asymmetric level. The funding for ALMPs have recently switched from being based on the number of employed to a number of performance indicators. This results-oriented system could lead to more transparency and more efficient 
use of resources. However, its success hinges on the correct design of the indicators, which must capture elements beyond the quantity and proportion of jobseekers benefitting from the services provided. For example, Australia assesses the success of employment agencies by the duration of the new employment, which serves as a proxy to the efficient matching of skills and jobs. Regular evaluations and readjustment of indicators should be continued in order to ensure that indicators are effectively measuring the degree to which the ultimate goals are being achieved.

Traditionally, a significant share of ALMPs has been skewed to employment incentives such as hiring subsidies for the unemployed, which can be costly and ineffective when they are not well targeted to the most vulnerable groups (OECD, 2018b and 2017c). Meanwhile, only $24 \%$ is spent on training and re-skilling, which stands close to the OECD average, despite skill mismatch being among the highest in the OECD.

Preliminary assessments suggest that in 2013-2015, activation policies have been more effective than in 2011-2013, especially for job-search assistance and professional guidance for the long-term unemployed (García Pérez, 2017). Hence, spending on training and jobsearch assistance should be prioritised, and be accompanied by continued evaluation. The Spanish Employment Activation Strategy (2017-20) reinforces the focus on multiannual planning and evaluation, which is needed to improve the effectiveness of policy changes and the efficiency of spending.

Regions, which control the bulk of spending in training ( $72 \%$ in 2016 ), also have a key role in increasing the effectiveness of ALMPs. According to the complaints to the Market and Competition Commission made under the Market Unity Law, regions discriminate in favour of local providers of training programs and limit entry by making requirements, such as permanent establishment and previous experience in the region, mandatory. Such restrictions can limit competition, increase the cost and reduce the quality of the programmes offered in a region. To improve the efficiency of ALMPs, regions must explicitly remove any barriers in their legislation that impedes competition among providers of training programs.

\section{Boosting labour mobility}

Mobility of workers is relatively low in Spain, with annual regional migration rates at $1 \%$, which is below the OECD average of $2 \%$ (Figure ). Greater mobility of workers could also help regions adjust to shocks. While there is evidence of migration of workers from regions with shrinking industries to those with growing ones in Germany, Korea and the United States, migration from weaker to better performing regions is low in Spain (OECD, 2017d). Spanish evidence also suggests that workers who have moved to better performing regions experience productivity gains that can benefit their region of origin in the case of return migration (De Roca and La Puga, 2017).

The high persistence of regional differences in unemployment rates have been linked to low cross-regional migration in Spain (Jimeno and Bentolila, 1998; Izquierdo et al., 2005). Despite an increase in regional differences in unemployment rates during the crisis, around 15\% of Spanish aged 18 to 64 moved between 2007 and 2012. 
Note: OECD average is the average of the 32 countries. Average 2013-2016, otherwise available years: Germany, Latvia and United Kingdom 2012-2015; Italy, 2011-2013; Greece, 2012; Slovenia and the United States, 2009-2011; the Netherlands, 2008-2010.

Source: OECD (2018), Regions and Cities at a Glance (database).

\section{Better integrating labour market and social policies}

Stronger coordination between employment and social services is key to providing effective transitions between social support schemes and employment, given the multiple barriers that the unemployed might face (OECD, 2017c; Fernandez et al., 2018). For example, participation in minimum income schemes in the Basque Country required recipients to participate in ALMPs. Such a direct link between passive and active policies may have contributed to the low negative impact of minimum income schemes on the transition to employment (De La Rica and Gorjón, 2017).

Improving coordination to provide integrated support for jobseekers via a single point of contact for social and employment services and assistance would improve the effectiveness of such policies. The structure of responsibilities of labour market and social policies are also spread across different levels of government, which makes cooperation between the central and regional governments essential for their effectiveness. The sharing of best practices across regions should be increased to facilitate their implementation in regions with higher needs.

Despite the existence of a number of mechanisms to enhance cooperation across regions and between authorities at different levels, there are gaps in the sharing of information, which can lower the effectiveness of policies and the integration of active and passive policies. To address some of these gaps, the authorities announced the launch of the 'social card' to include all non-contributory benefits received regardless of its source (national, regional or local). This is a step in the right direction that should be implemented immediately and could be extended to other services provided by Public Employment Services, such as the active labour programmes the individual is enrolled in.

Barriers to inter-regional transition of the entitlements of recipients and disparities in the coverage of income benefit schemes could also restrict regional mobility (Ayala et al. 2016). The decision to move to a region with higher employment opportunities can be 
adversely affected by uncertainty regarding the potential loss of social benefits. The creation of a Basic Catalogue of Social Services in 2013, which includes all services regions must provide, is a good initial step to reduce information asymmetries. A comprehensive 'map of social benefits', which includes all regional benefits, would deliver a better understanding of the system to potential beneficiaries. This information should be utilised to ensure the portability of social rights across regions in a transparent manner.

In many cases, having access to social and housing benefits requires previous residence, which could expose beneficiaries to long periods without assistance if they decide to move, and restrict labour mobility. Providing temporary assistance to those who move across regions, either by the region of origin or the central government, should be considered to achieve full portability of these benefits across regions. This is especially important in the case of minimum income guarantee schemes, which are designed, financed and evaluated at the regional level. Around $80 \%$ of recipients of such schemes have only reached the first stage of secondary education or below, suggesting that non-transferability of benefits across regions can disproportionately affect less-educated individuals, who are already less likely to move. This could be combined with a general evaluation of these schemes, which tend to provide minimal support and are not targeted well, with a view to increase the amount and coverage of the effective ones (OECD, 2017c).

\section{Making housing more flexible and affordable}

Policy interventions in housing markets may affect geographical and, in turn, labour mobility and could give rise to misallocation of labour (Andrews, Caldera Sánchez and Johansson, 2011; van der Vilst et al., 2002). For example, high owner-occupation rates may be associated with an increase in the unemployment rate due to lower mobility (Oswald, 1999). The withdrawal of deductibility from income tax of mortgage payments in 2013 has reduced the tax advantage of home ownership in Spain, but the rate of home ownership at $77.8 \%$ in 2016 is among the highest in the OECD. The association of home ownership rates and labour mobility may have been further exacerbated due to the severe crisis and the sharp drop in house prices (Palomares-Linares and Van Ham, 2016), and the asymmetric changes in house prices across regions, as discussed below.

High transactions costs (e.g. stamp duties, registration fees, etc.) may create lock-in effects in the housing market (Van Ommeren and Van Leuvensteijn, 2005). Transactions costs, which remain above the OECD average in Spain, have been associated with higher skill mismatch (Adalet McGowan and Andrews, 2015; Caldera Sánchez and Andrews, 2011). Simulations show that reducing transaction costs in Spain to the minimum level in the OECD may be associated with a reduction in the probability of mismatch by around 0.2 percentage points, implying potential gains to labour productivity of 1.6 percentage points (Adalet McGowan and Antona San Millán, 2018). Other policies that are associated with lowering skill mismatches are discussed below.

A large and flexible rental market is also key, since stringent rental regulations may lower residential construction and reduce the mobility of incumbent tenants (Sims, 2007; Lind, 2001) and reinforce homeownership bias. In 2013, changes in regulation increased legal certainty for the tenant and reduced restrictions in contracts favouring agreements between parties over legal statutory duties. Furthermore, arbitration bodies to handle disputes between landlord and tenants were created in some regions, as recommended in the 2014 Economic Survey of Spain. Extending these to all regions would improve the flexibility of the rental market. The government recently launched a study to analyse the barriers in the 
rental market and an inter-ministerial working group was created to improve rental market regulation, which is welcome.

Housing affordability can be a barrier to the mobility of workers, especially for young and low-income ones. The affordability of private rental markets is amongst the lowest in the OECD, with more than a quarter of private market tenants overburdened by rent costs in Spain (Salvi del Pero et al., 2016) (Figure, Panel A). Low-income households - those in the bottom quintile of the income distribution - are more likely to be overburdened by housing costs (Figure, Panel B). After the crisis, rents have increased disproportionately more in big cities and urban areas, and regions where employment opportunities are higher. The National Housing Plan 2018-21 includes house allowances for the youth and lowincome families. While it rightly focuses on the most vulnerable, the redistributive effect may be limited in areas where demand is high and supply scarce, as subsidies could lead to increases in rental prices.

Figure 15. Burden of housing costs, especially for tenants and low-income households, is high

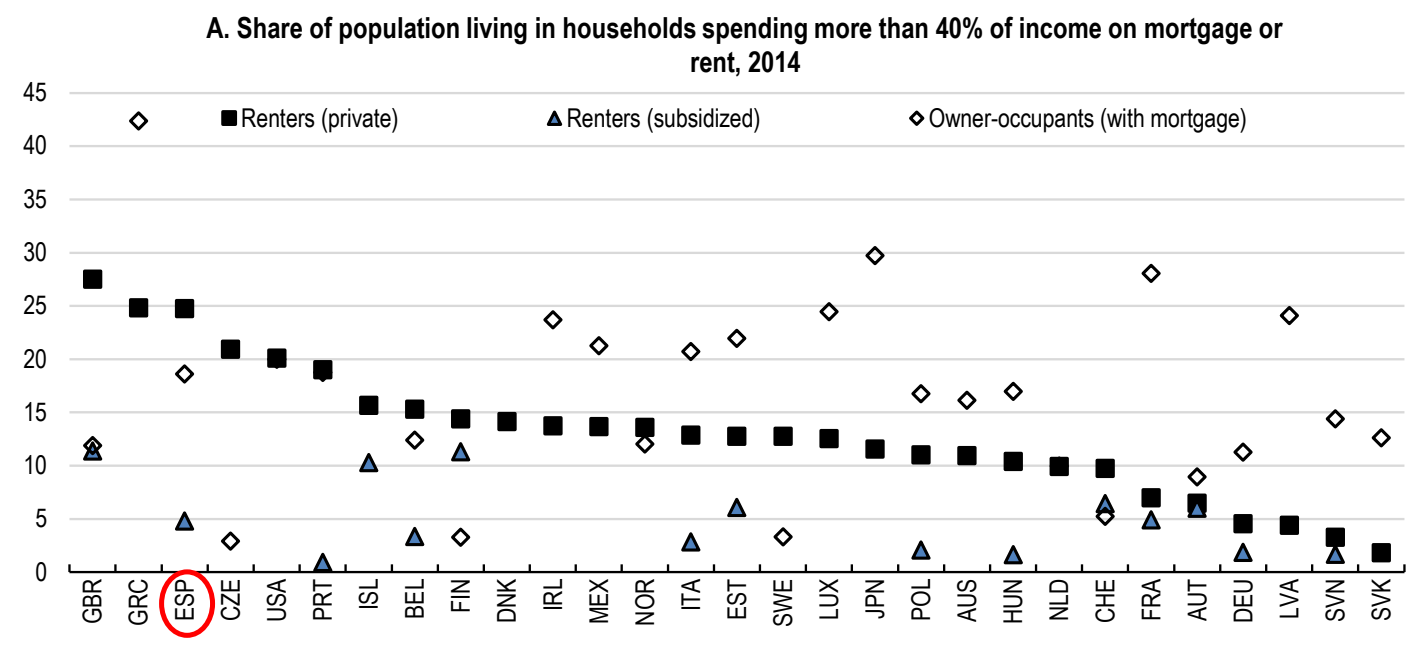

B.Share of households in the bottom quintile of the income distribution spending over $40 \%$ of disposable income on mortgage or rent, 2014

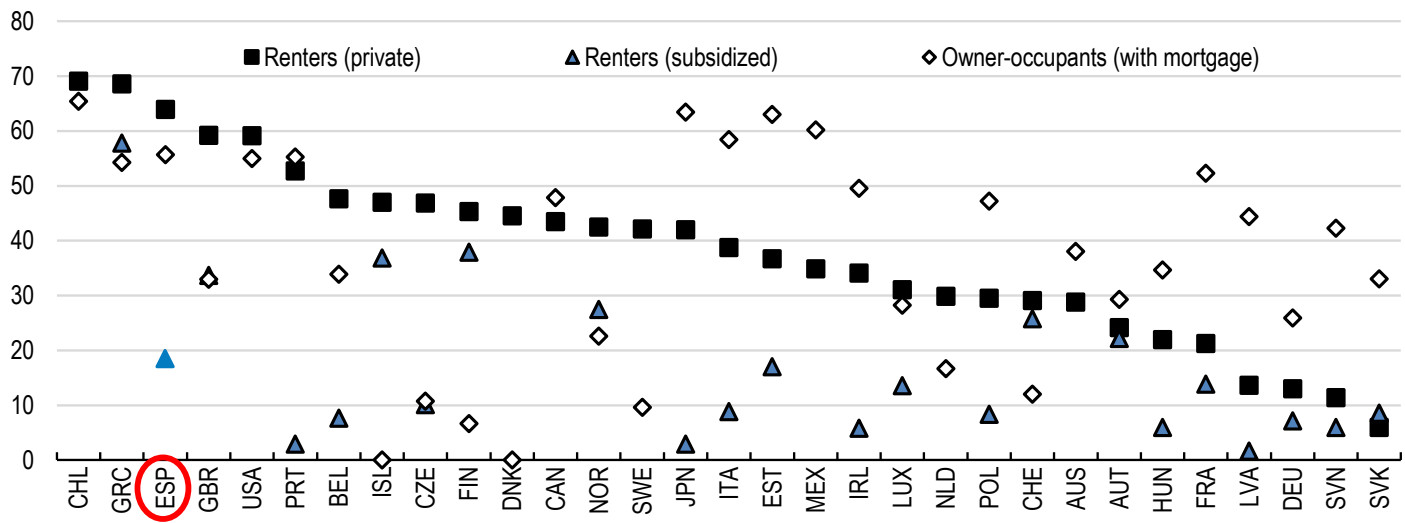

Source: OECD, Affordable Housing Database.

Social housing in Spain has traditionally been tilted towards ownership rather than rental properties. This might have contributed to lower mobility due to restrictions to prevent potential misuse of social housing, such as impediments for selling off or renting the 
property for a number of years. The new government plans to reorient the Housing Plan more towards public and rental housing, with a plan to promote a park of 20000 public housing units in four years.

The authorities recently announced subsidies to increase the stock of rental houses at capped prices aimed at low-income families. Means-testing to track changes in eligibility conditions should be made regularly and households above eligibility thresholds encouraged to move out by aligning their rents to market prices. Housing programmes are mostly run by the regional and local governments. Hence, to facilitate inter-regional labour mobility, it is important that regions mutually and automatically recognise beneficiaries from other regions and share information on the availability of housing-related benefits in other regions.

\section{Lowering regional disparities in education outcomes}

Human capital is a robust determinant of regional growth across the OECD and Spain (OECD, 2016c; Kerimoglu and Karahasan, 2011; OECD, 2009), but regional disparities in education outcomes are high in Spain (Table ). Increasing the quality of education would improve the employability of the labour force in lagging regions and should be complemented with policies to raise job quality in regions with low-skilled jobs. A higherskilled workforce would also make lagging regions more attractive for firms. Policies should focus on improving the skills of workers, better matching skills to future and regional labour market needs, and reducing inequality of opportunity.

The incidence of skill mismatch, defined as the share of workers reporting a mismatch between their existing skills and those required for their job, at 33\% is amongst the highest in the OECD, with significant regional differences (Adalet McGowan and Antona San Millán, 2018). A wide range of policies can help reduce skill mismatch and boost productivity in Spain, including more flexible product and labour market policies and housing policies. Promoting lifelong learning could yield large gains in terms of reducing skill mismatch and boosting productivity, which should be a priority for regions with low skills (Figure ). 
Table 1. Regional differences in education outcomes

\begin{tabular}{lcccc}
\hline & $\begin{array}{l}\text { Share of students } \\
\text { with science } \\
\text { proficiency at Level 1 } \\
\text { or below }\end{array}$ & $\begin{array}{l}\text { Share of students } \\
\text { with reading } \\
\text { proficiency at Level 1 } \\
\text { or below }\end{array}$ & $\begin{array}{l}\text { Share of students } \\
\text { with mathematics } \\
\text { proficiency at Level 1 } \\
\text { or below }\end{array}$ & $\begin{array}{l}\text { Difference in science } \\
\text { performance of } \\
\text { migrants and natives, } \\
\text { after accounting for } \\
\text { socio economic status }\end{array}$ \\
\hline Andalucia & $\mathbf{2 0 1 5}$ & $\mathbf{2 0 1 5}$ & $\mathbf{2 0 1 5}$ & $\mathbf{2 0 1 5}$ \\
Aragon & 25.4 & 22.4 & 30.2 & 32 \\
Asturias & 14.2 & 14.2 & 17.1 & 48 \\
Balearic Islands & 16.4 & 16.3 & 20.6 & 30 \\
BasqueCountry & 20.4 & 19.1 & 25.0 & 31 \\
Canary Islands & 20.2 & 17.4 & 19.5 & 38 \\
Cantabria & 23.8 & 21.1 & 35.9 & 10 \\
Castile and Leon & 17.3 & 14.9 & 19.4 & 37 \\
Castille-La Mancha & 10.2 & 9.0 & 14.6 & 35 \\
Catalonia & 16.2 & 14.9 & 21.4 & 28 \\
Valencia & 15.7 & 15.4 & 17.7 & 42 \\
Extremadura & 15.8 & 14.4 & 20.3 & 24 \\
Galicia & 24.3 & 23.0 & 27.0 & 36 \\
La Rioja & 13.4 & 13.3 & 18.6 & 46 \\
Madrid & 17.0 & 18.1 & 16.4 & 32 \\
Murcia & 12.2 & 10.8 & 16.5 & 31 \\
Navarra & 21.1 & 19.4 & 27.9 & 26 \\
\hline OECD & 11.9 & 11.2 & 12.1 & 31 \\
\hline
\end{tabular}

Note: The top 3 performing regions in each category are in bold and shaded in blue. If the performance of the region is below the OECD average, it is shaded in orange.

Source: OECD, PISA 2015.

Figure 16. Potential gains to productivity from policy reforms that reduce skill mismatch

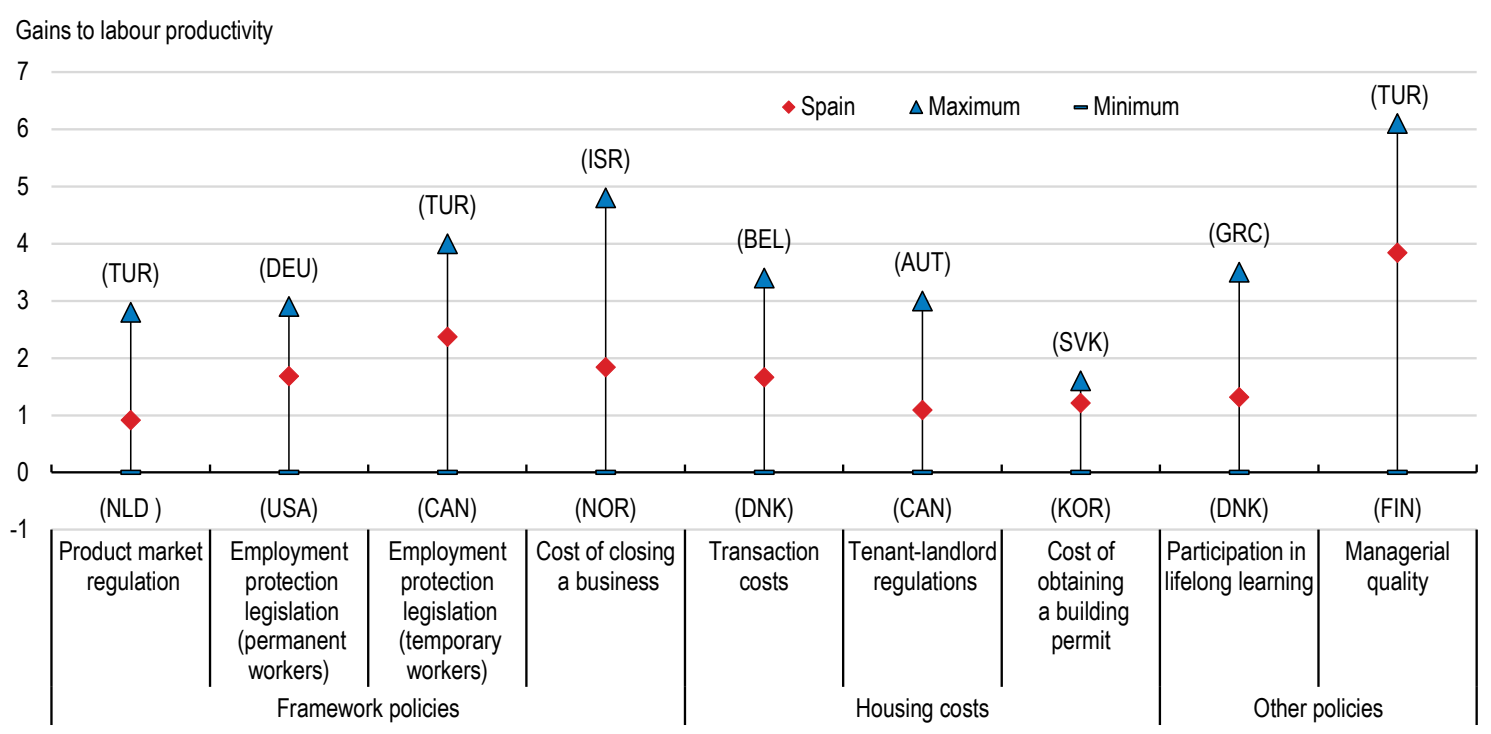

Note: Estimates are based on: i) logit regressions of probability of mismatch controlling for age, marital and migrant status, gender, education, firm size, contract type, a dummy for working full-time and working in the private sector; and ii) OLS regressions of labour productivity on skill mismatch.

Source: OECD calculations, based on Adalet McGowan, M and D. Andrews (2015). 


\section{Improving the adaptability of workers through lifelong learning}

Lifelong learning has a key role to play in helping workers cope with technical progress by raising skill levels and reducing skill mismatches. In turn, higher skills can contribute to increasing social mobility, attracting firms to lagging regions and improving productivity. Lifelong learning is important in Spain since skill proficiency is among the lowest across OECD countries and forecasts of future skill needs suggest that the labour market will require a significant increase in the number of workers with high qualifications (CEDEFOP, 2015).

Participation in lifelong learning in Spain, at 9.9\% in 2017, is below the EU average of $10.9 \%$ and the EU average target of $15 \%$ set by the Education and Training 2020 framework (Figure, Panel A). A number of recent initiatives could support participation in lifelong learning, but it is too early to assess their effect (Box 2). It is important to ensure that the provided training are of high quality, of relevance to labour market needs and target those who would benefit the most from further training.

There is room to improve the targeting of the available financial resources for training. Survey-based evidence suggests that financing is not considered to be a main barrier to participation in Spain, with only around $8 \%$ of adults citing funding as an obstacle, which is below the EU average of 13\% (European Commission, 2015). An important source of financing of formal training for the employed and unemployed in Spain is the professional training levy (Cotización para formación profesional), which both employers and workers contribute to. However, the levy funds are often used for mandatory workplace training (e.g. health and safety), rather than to address skill needs, suggesting a need to reorient publicly-subsidised training for the employed and unemployed to skills and qualifications which are in high demand (OECD, 2018b).

\section{Box 2. Recent initiatives in lifelong learning}

The Lifelong Learning Strategic Plan 2014-20, in collaboration with regional and local educational authorities, aims to improve access and flexibility, boost participation and improve the quality of lifelong learning opportunities. The Plan provides access to distance formal education and to obtain credentials in secondary education, and resources, such as online learning portals.

In 2015, two measures were proposed to promote lifelong learning for workers: training leave and individual training accounts (Cuenta Formación). In July 2015, the social partners agreed to work together in the establishment of the single training account for all workers, the definition of a new training needs catalogue in enterprises, and a better evaluation of the delivered professional training. The Chambers of Commerce are getting progressively involved in the scheme at national and regional level to encourage participation by local businesses, but the low capacity of small and medium-sized enterprises (SMEs) to absorb trainees can be a barrier.

Similar to other countries, the likelihood of participation in lifelong training is higher for employed, younger, more educated and native individuals in Spain (Felgueroso, 2017). International evidence suggests that funding targeted at vulnerable groups may partly boost participation by those adults who need it most (Rubenson and Desjardins, 2009). This should be an important priority, given that the participation of low-qualified adults at $3.5 \%$ remains low (Figure, Panel B). 
Figure 17. Participation in life-long learning across Europe by educational attainment

A. Participation in life-long learning

Per cent of population aged 25-64 participating in education and training in the preceding 4 weeks, 2017

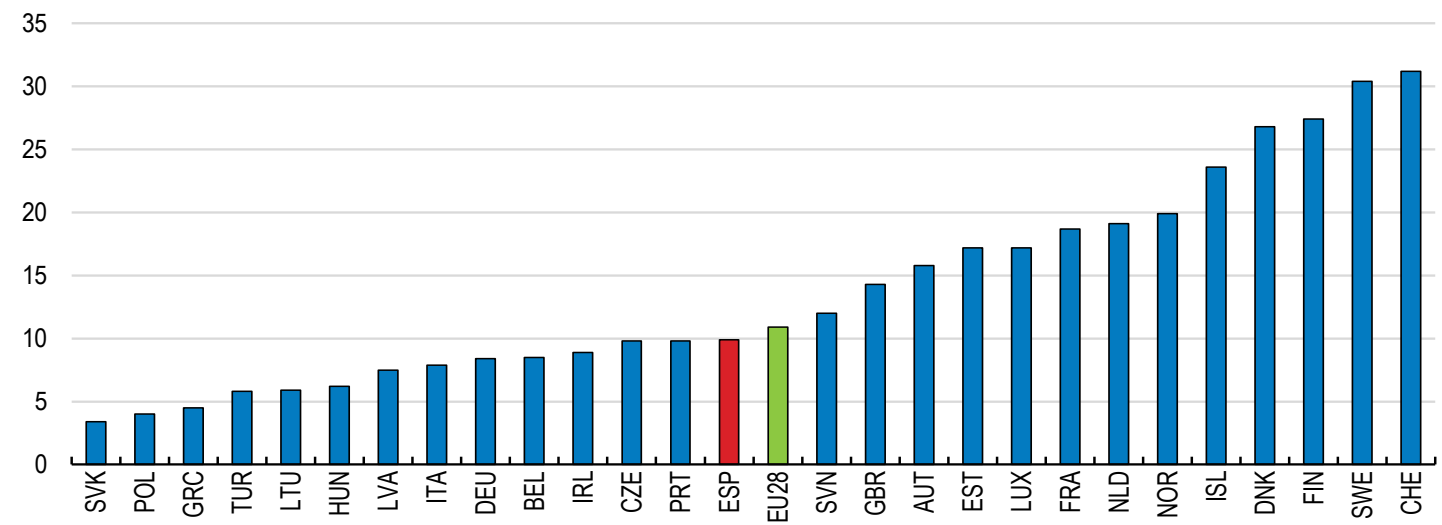

B. Participation in life-long learning by level of educational attainment

Per cent of population aged 25-64 participating in education and training in the preceding 4 weeks, 2017

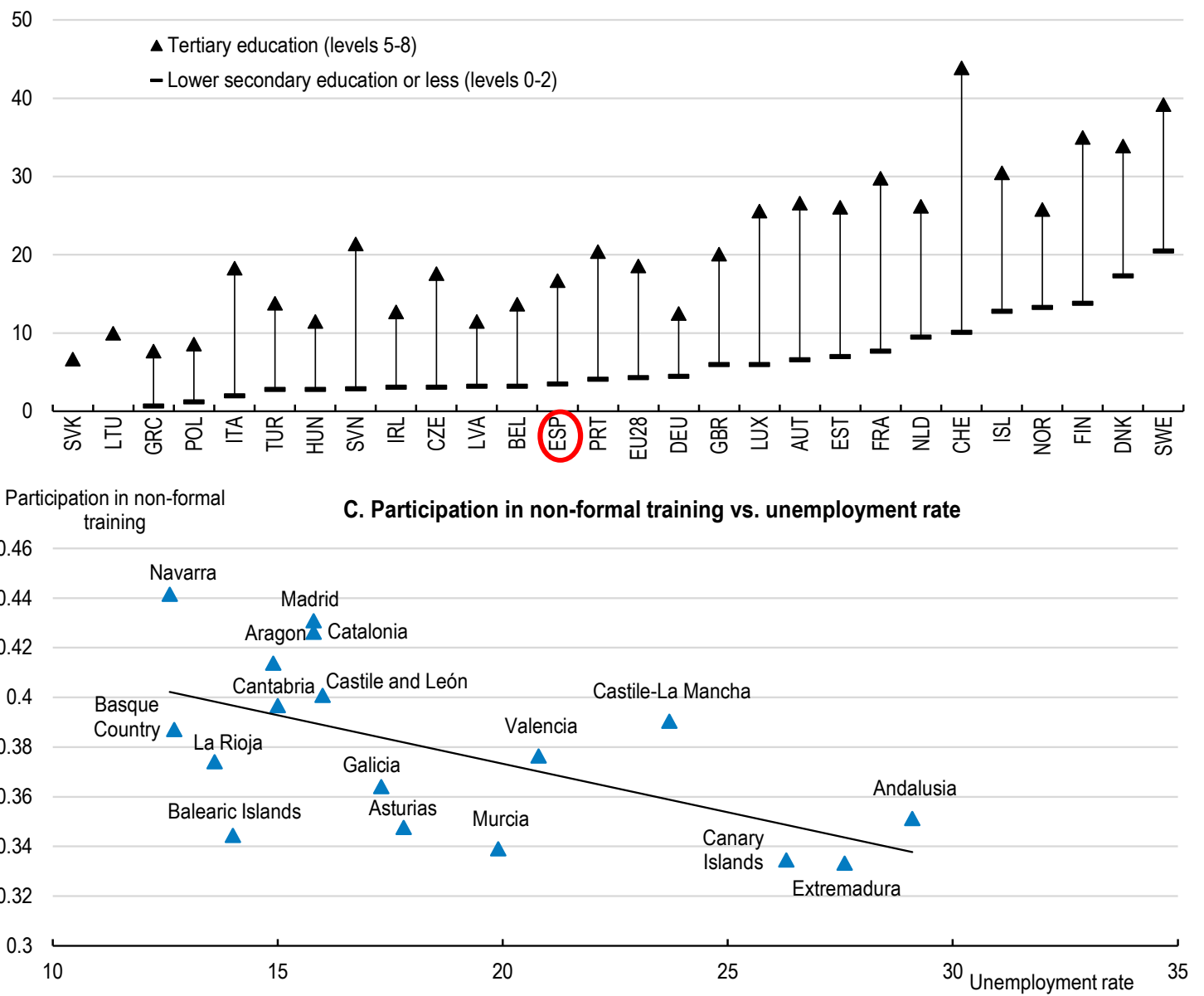

Note: In Panel B, countries are ranked according to the participation rate in lifelong learning by those with lower secondary education level or less. Levels refer to the International Standard Classification of Education (ISCED).

Source: Eurostat, INE, Labour Force Survey, and OECD Regional Statistics. 
Financial incentives tend to be geared towards jobs and training centres, rather than individuals in Spain. While this can contribute to ensure that any additional training is more likely to meet specific labour market needs, subsidies for individuals could work better when targeting vulnerable groups. In Spain, the recently introduced individual training accounts (Cuenta Formación) are used to keep track of training participation and qualifications over the course of workers' careers, but often are not tied to funding, as in other countries (OECD, 2018b). Financial incentives for lifelong learning opportunities targeted at low-qualified workers that are linked to individuals rather than jobs should be introduced.

Assistance with childcare, transport and access to social services can increase participation in lifelong learning (Benseman, Sutton and Lander, 2005). The most common barriers to participation in lifelong learning in Spain are family responsibilities (31\%) and conflicts with work schedules $(17 \%)$, which are higher than the EU average of $17 \%$ and $14 \%$, respectively. The former could partly explain the lower incidence of participation of women in informal training activities (Chlon-Dominczak and Lis, 2013). Between 2007 and 2012, participation rates in informal training by women decreased, while those of men increased, widening the gender gap in such training (Calero and Escardibul, 2015). Extending the provision of childcare to children between the ages of 0 and 3 and longdistance learning opportunities (see below) could help improve gender equality in participation in lifelong learning.

Digitalisation provides opportunities for improving the flexibility of lifelong learning, but strategies for lifelong learning do not fully integrate the use of digital technologies in Spain (European Commission, 2015). Regional differences in both digital skills and infrastructure can lead to differences in the utilisation of long distance lifelong learning programmes. Households' broadband access varies across regions in Spain, which could lower the effectiveness of such initiatives (OECD, 2016b). Efforts to boost access to digital networks in lagging regions and reducing regional disparities in the ability to use digital technologies, as discussed below, should be continued.

\section{Ensuring a better matching of skills with labour market needs}

\section{Training vouchers}

Participation in non-formal training is low in regions where unemployment rates are high (Figure, Panel C). In 2017, training vouchers for the unemployed, allowing them to fund training programs of their choice, was approved. Training vouchers increase the freedom of choice of participants, which should improve the matching between participants and training centres. However, lack of knowledge on labour market needs and the associated wage premium, and the performance of different training providers could lower their effectiveness (Barnow, 2009). International experience suggests that a number of design features could be useful. For example, Korea provides guidance on the use of vouchers towards skills that are high in demand to improve employment outcomes, and in Estonia, vouchers can only be used on training programmes in areas of labour market or skill needs (Felgueroso, 2017; OECD, 2018b).

The implementation of the training vouchers will be the responsibility of regional governments, which is welcome, since matching training to labour market needs works best if a regional approach is taken. For example, in Finland, training courses are purchased through public procurement by regional centres of economic development, whose choice of courses to purchase is based on estimated regional labour market needs (OECD, 2017e). 
Regional programmes should use counsellors to give guidance to the unemployed on the use of training vouchers, providing individualised support in line with the specific profile of the participant and consider linking the choice of training programmes to local labour market needs. Given that these subsidies could create deadweight costs, regular ex-post evaluations should be carried out.

\section{Vocational education and training}

Vocational education and training (VET) is important to lowering youth unemployment and early school leaving rates, and facilitating the transition of young people from education to work. The development and modernisation of VET should be continued, as recommended in the 2017 Economic Survey of Spain. The new government has made this a top priority and developed a Strategic Plan for VET, which is welcome. Specifically, the plan includes extensions of initiatives and training modalities to obtain VET diplomas (e.g., dual VET, distance and online learning VET, offers of modular programmes), improvements to the recognition of the competences acquired through pathways other than formal training (e.g., the accessibility to the procedures for the accreditation of basic skills for adults), update of continuous training of VET teachers (e.g., promotion of the specialised training-company work placement and further implementation of innovative training methodologies) and increased initiatives to boost national and international teacher mobility.

The dual VET system is a crucial part of aligning skills of young people with the needs of employers. The ability of employers to influence the design of curricula is key to ensure that the skills being developed are in line with their needs and introduces flexibility to system. However, there are regional differences in the implementation of the on-the-job training component, which can introduce the risk that the skill-signalling power of these qualifications is reduced $(\mathrm{OECD}, 2018 \mathrm{~b})$. This could be a reflection of the regional differences in the number of firms providing dual VET (OECD, 2017c). Hence, the involvement of firms in the design of such programmes should be balanced with introducing minimum standards on the practical part of these programmes.

\section{Boosting digital skills}

Increased information and communications technology (ICT) adoption has contributed to the polarisation of jobs away from middle-skilled jobs and into low-and high-skilled jobs across OECD countries, including in Spain (OECD, 2017f; Oesch and Rodriguez Menes, 2011). However, automation, unlike other waves of technological progress, is expected to disproportionately affect low-skilled jobs, placing downward pressure on wages and can have large implications for inclusiveness (Nedelkoska and Quintini, 2018; Dauth et al., 2017). The percentage of workers in jobs at high risk of being automated in the next 15-20 years at $21 \%$ in Spain is higher than the OECD average of $14 \%$ (Nedelkoska and Quintini, 2018) (Figure). 
Figure 18. The changes in nature of jobs require new skills

Percentage of workers in jobs at high risk of being automated or in jobs facing significant change

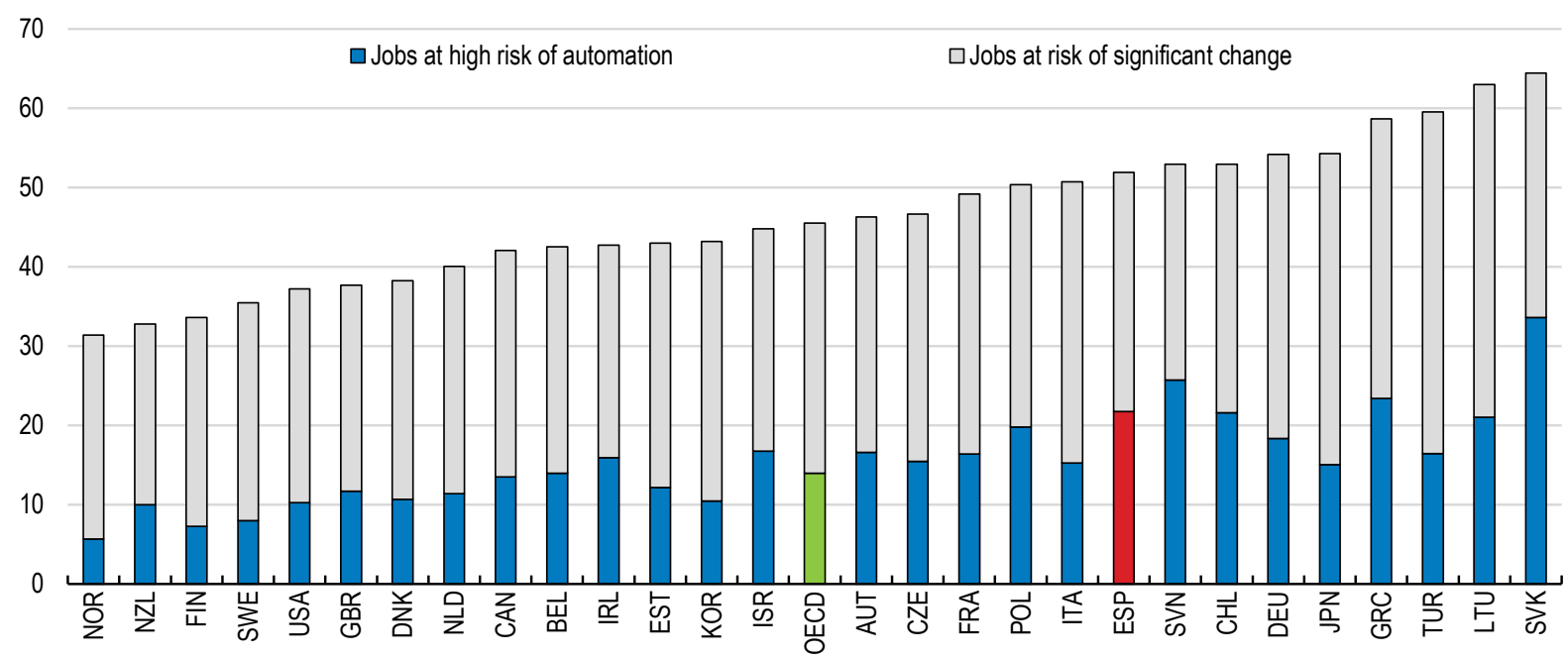

Note: Jobs are at high risk of automation if the likelihood of being automated is at least $70 \%$. Jobs are at risk of significant change if the likelihood of being automated is between 50 and $70 \%$.

Source: Nedelkoska, L. and G. Quintini (2018), "Automation, skills use and training”, OECD Social, Employment and Migration Working Papers, No. 202, OECD Publishing, Paris.

According to Eurostat's Digital Skills Survey, only 32\% of working age Spanish had "above-basic" digital skills in 2017, which is around the EU average, but below some peer countries. Furthermore, young, high-qualified and high-income individuals tend to have a higher level of digital skills (Figure ). While these patterns are also observed in other peer countries, the differences in digital skills by income are starker in Spain. In Nordic countries, even people with low education display relatively high levels of acquaintance with digital technologies. This is in line with other evidence, which shows that the gap in internet use by educational attainment is relatively high in Spain (OECD, 2017g). Targeting training in digital skills to low-qualified and low-income individuals would help address these disparities. 
Figure 19. There is scope to improve digital skills

$\%$ of respondents claiming to have basic digital skills

A. By age

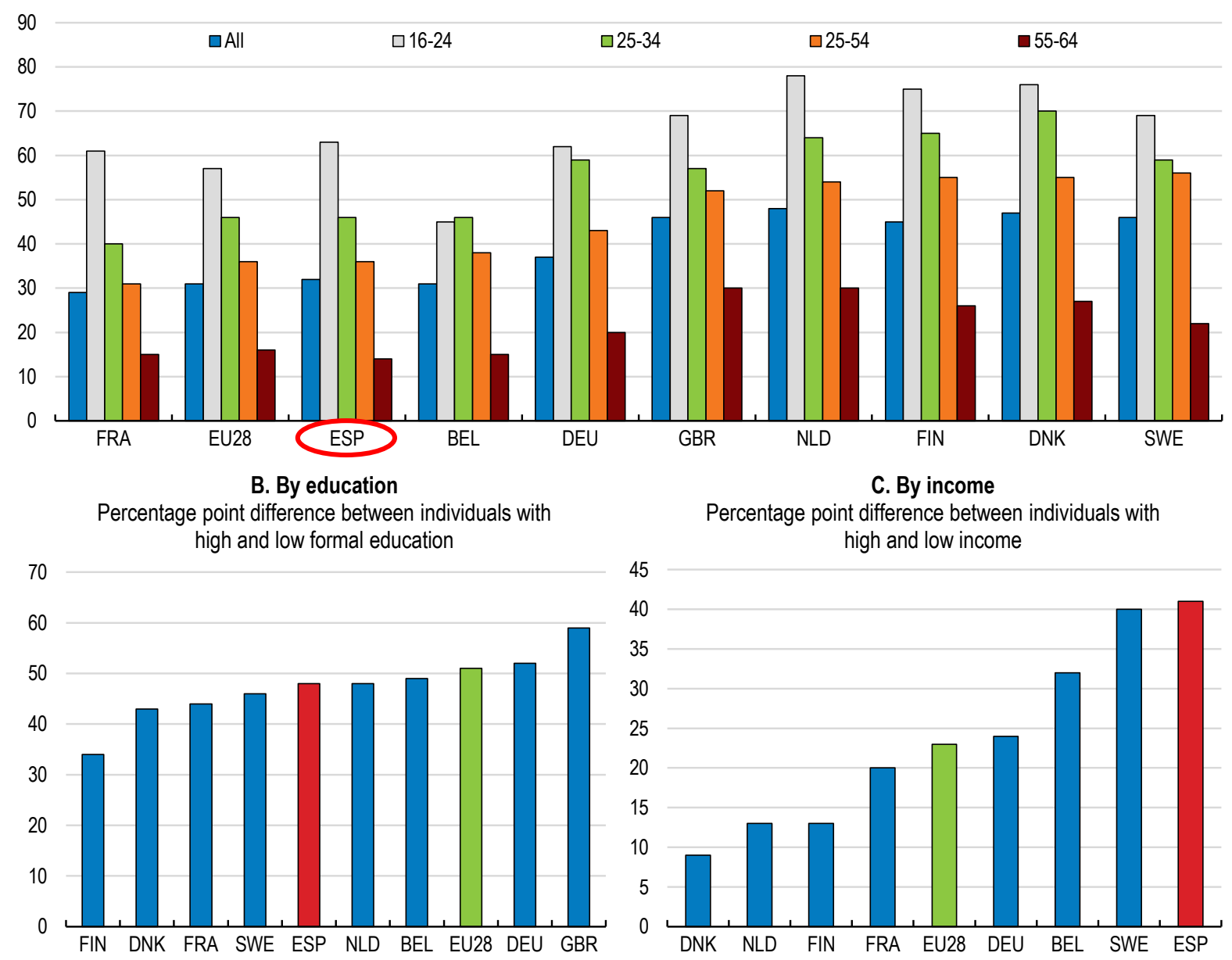

Note: In Panel C, high income refers to individuals living in a household with income in the fourth quartile and low income refers to individuals living in a household with income in the first quartile.

Source: Eurostat.

The adoption of digital technologies by firms is relatively low in Spain, with significant regional differences (Figure). Changes due to digitalisation can increase regional inequalities, with new jobs created in places other than where they have been destroyed and where skills are available (Berger and Frey, 2016). Low levels of ICT use by firms can be associated with a lack of firm dynamics, as digital transformation lowers entry barriers and facilitates reallocation (Calvino and Criscuolo, 2018). International evidence suggests that managerial quality, the availability of digital skills and low levels of skill mismatch boost digital technology adoption (Andrews, Nicoletti and Timiliotis, 2018). Hence, policies in a number of these areas, as discussed elsewhere in the paper, would help. 
Figure 20. Spanish firms lag in their use of key digital technologies

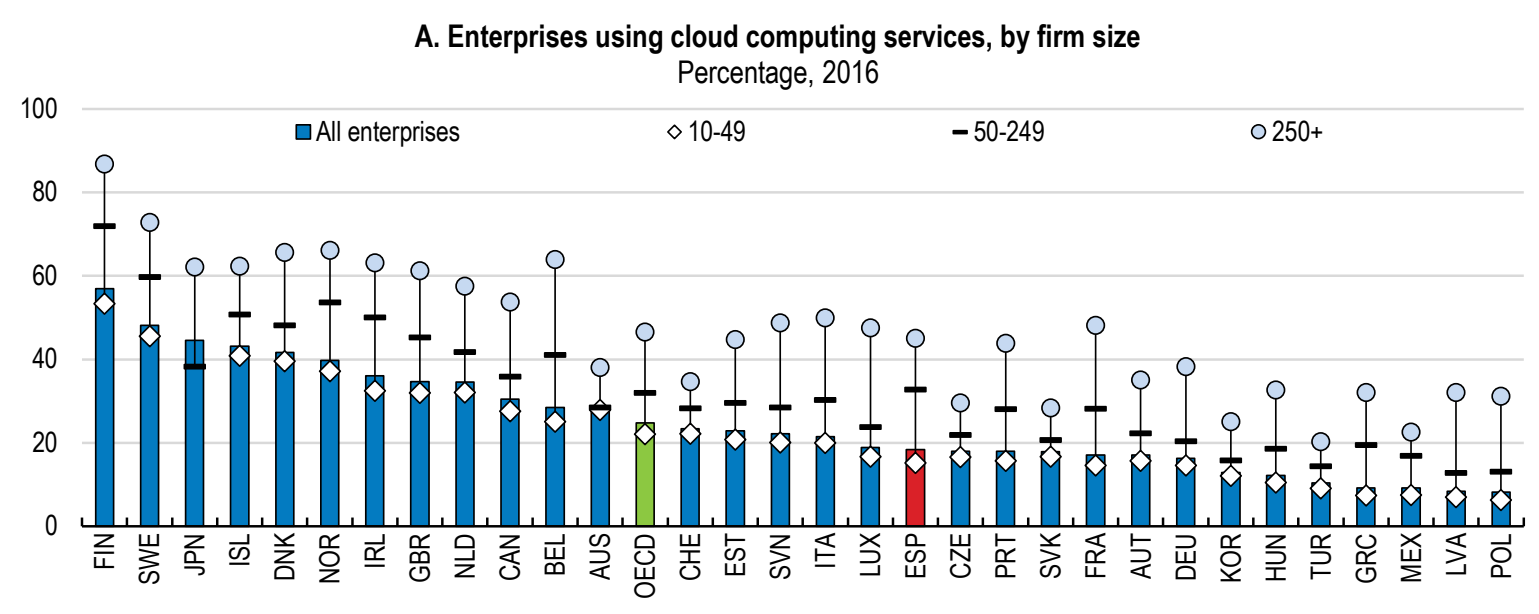

B. Regional differences in adoption of digital technologies by firms Percentage, first trimester of 2017

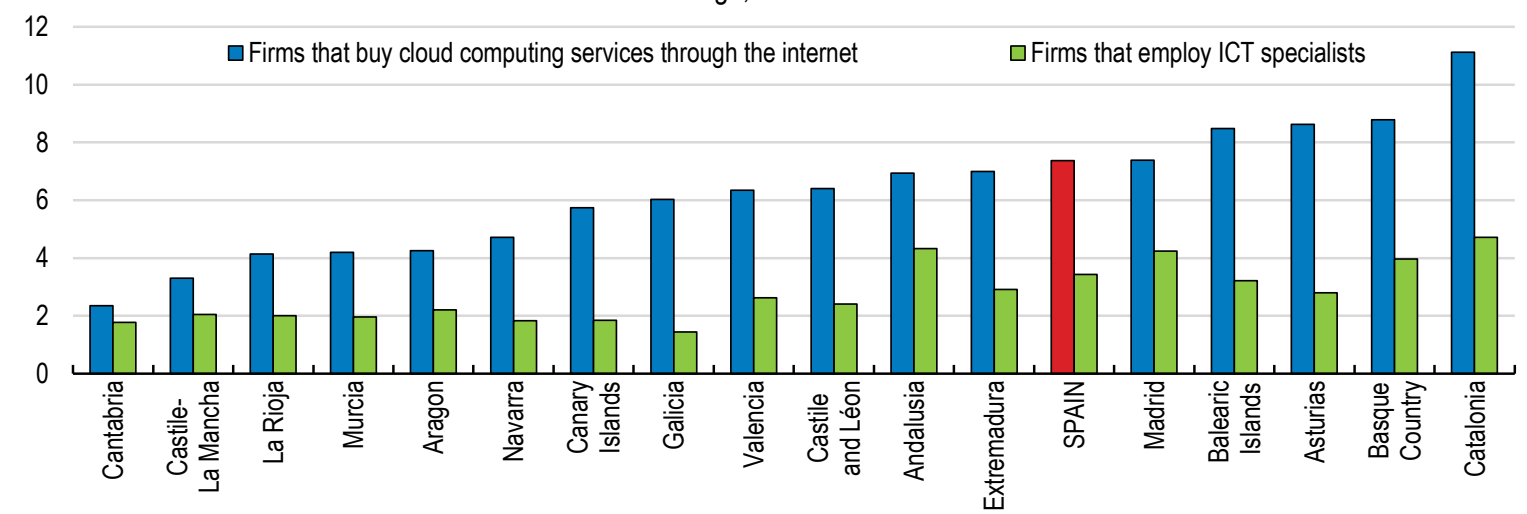

Note: Cloud computing refers to ICT services used over the Internet as a set of computing resources to access software, computing power, storage capacity and so on. Data refer to manufacturing and non-financial market services. OECD data are based on a simple average of the available countries. Source: OECD (2017), OECD Digital Economy Outlook 2017 and INE.

Recent evidence links firm adoption of digital technologies across Spanish regions with the regional share of young people, highlighting the complementarities between the demand and supply of digital skills (Cámara and Ruiz Sánchez, 2017). A number of individual initiatives exist to improve digitalisation, but they should be evaluated and streamlined to develop a comprehensive strategy (Box 3). Such a strategy should aim at helping workers to navigate the implications of the digital transformation for jobs and creating the right infrastructure and framework conditions for firms to adopt digital technologies. The government is currently working on the new Digital Strategy for Smart Spain, which should ensure complementarities between the availability of skills and the needs of firms, especially at the regional level, given regional differences. 


\section{Box 3. Existing policies to boost digital skills and adoption}

In 2015, an industrial strategy (Industria Conectada 4.0) to encourage the use of digital technologies in firms, which provides manufacturing firms with the information (on-line self-diagnostic tool), guidance (consulting service) and financing they may require in adopting digital technologies, was introduced. In 2017, two initiatives (Asesores Digitales and Oficinas de Transformación Digital), which provide advisory services to SMEs in the digital transformation of their activities, were launched.

There are also a number of public and private initiatives to develop training programmes aimed at young people to improve digital skills. Measures were also taken to improve the digital competencies of teachers via the Digital Skills and Competence Framework and the development of open online courses, including in ICT skills.

\section{Raising the overall level of basic skills and increasing equality of opportunity}

Despite significant improvements over the past years, the early school leaving and grade repetition rates remain high, which increases the risk of school drop-outs, lowers attainment expectations and weighs on education costs (OECD, 2012a). From a regional perspective, higher grade repetition rates are associated with higher early leaving rates (Figure ).

Figure 21. Grade repetition and early school leaving rates are positively related at the regional level

Early school leaving rates

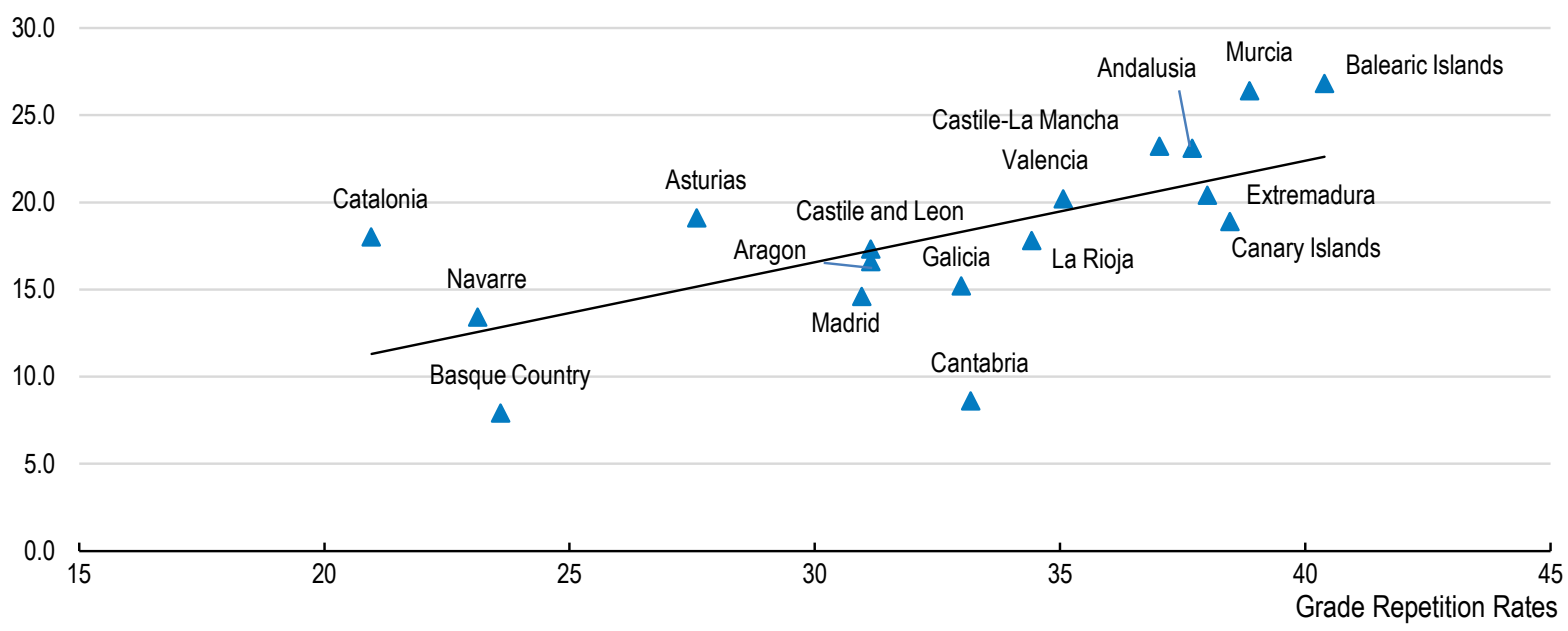

Source: OECD (2016), PISA 2015 Results (Volume II): Policies and Practices for Successful Schools (database); and Eurostat (2018), Early leavers from education and training (database).

Lowering early leaving rates at the regional level, with a special focus on teacher training and evaluation and individual student support, which are among the drivers of successful schools in well-performing regions, will be essential. For example, there is evidence that early intervention, additional instruction and individualised learning can lower grade repetition rates, as was the case in Finland (Välijärvi and Sahlberg, 2008). However, the percentage of students enrolled in schools where staff helps with homework is $35 \%$ in Spain, well below the OECD average of $60 \%$. Reversing the culture of grade retention by 
raising teacher awareness of the consequences and setting specific targets to hold schools accountable, as was the case in France in 2008, would also help.

The increased likelihood of grade repetition among disadvantaged students compared with their advantaged peers, and after taking performance into account, is amongst the highest in the OECD (OECD, 2016d). Furthermore, the percentage of variance in science performance explained by socio-economic background displays large regional differences (Figure ). For example, Castille-Leon, which has good education outcomes for disadvantaged students, has focused on individualised help, early detection of learning difficulties and initial evaluation of basic abilities (Box 4). Individualised support time, as was done in France in 2016, but targeted at students at the risk of failing, should be introduced. This can be complemented with the use of national standardised tests widely in primary and secondary education, as recommended in the 2017 Economic Survey of Spain, to identify students in need. The new government is developing a renewed scholarship system to improve equality of access to education, including increased resources and a special focus on students from disadvantaged backgrounds, which should also contribute to lower early school leaving rates.

Figure 22. Education outcomes vary by socio-economic conditions

Percentage of variance in science performance explained by socio-economic background

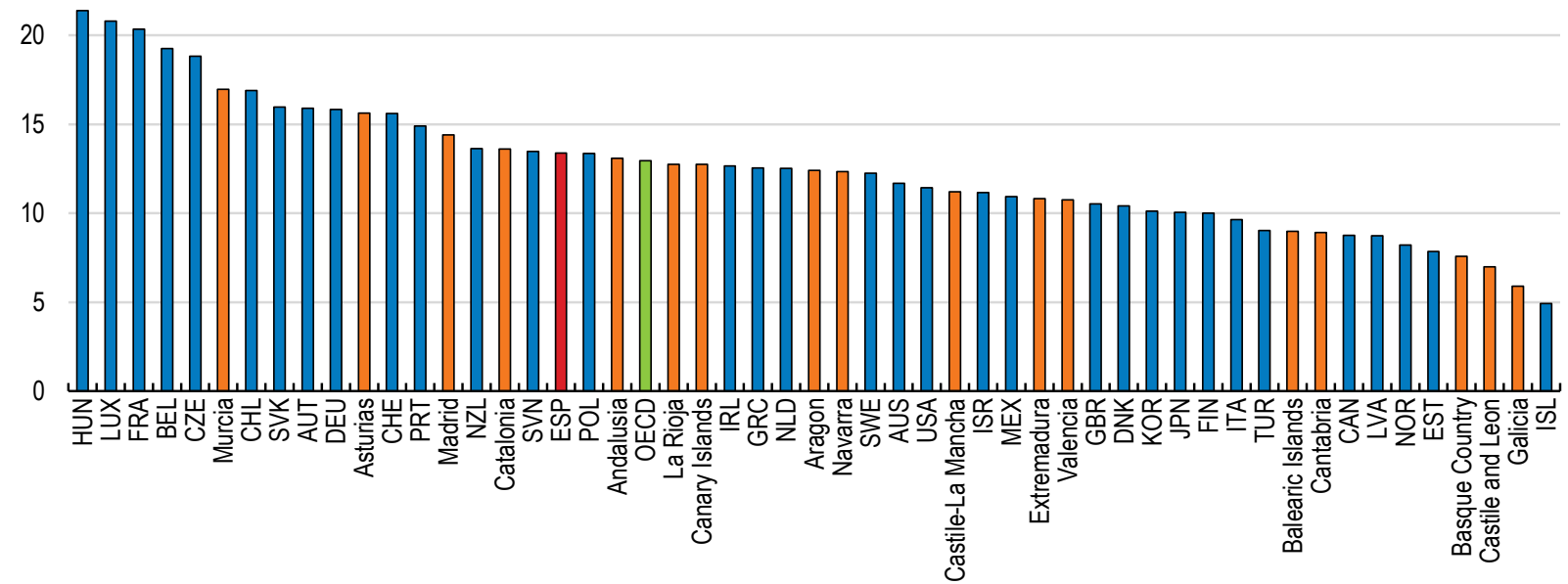

Source: OECD (2016), PISA 2015 Results (Volume II): Policies and Practices for Successful Schools, OECD Publishing.

While disadvantaged public schools tend to have smaller classes and/or smaller studentteacher ratios than advantaged public schools, there is a lack of clear allocation of the most qualified and experienced teachers to the most challenging schools (OECD, 2018c). In Japan and Korea, there are policies to ensure that high-quality teachers go to disadvantaged schools, via formal and informal schemes to ensure that teachers periodically change schools, and extra incentives, such as additional salary, less instruction time and the ability to choose their next school (OECD, 2018d). Improving incentives for the mobility of wellqualified teachers across schools and regions is another way to spur growth and increase equality of opportunity in lagging regions. 


\section{Box 4. Achieving good education outcomes: the case of Castille-Leon}

While Castille-Leon is not among the wealthiest regions, with a GDP per capita below the national level, it achieves good education outcomes. According to PISA results, students from the region have a high overall performance (above 500 points) in reading, mathematics and science. To help students perform well regardless of their socioeconomic status, the region has developed programmes to provide primary students with support during school hours and extracurricular lessons to help with preparation for exams. Continuing professional development for teachers has also been encouraged via a network of 'training and innovation' centres.

Ensuring that teacher and principal appraisal is fully part of a strong assessment and evaluation framework is key to improving education outcomes, but Spain lacks a formal national teacher appraisal system (OECD, 2016d). Each region is responsible for the appraisal of its teachers, but PISA findings suggest that teachers in Spain have few opportunities to receive appraisal. According to school principals' reports, only $32 \%$ of students are in schools where the principal observes lessons (compared to the OECD average of $81 \%$ ), and only $27 \%$ of students are in schools where peer reviews are utilised (compared to the OECD average of 66\%). There are also large regional differences, with $71 \%$ of students in schools where the principal observes lessons in Catalonia, compared to $10 \%$ in Extremadura. Since regional authorities will play a lead role in school evaluation, it is important that they develop the capacity to fulfil these tasks.

\section{Boosting productivity and firm dynamism across regions}

Boosting overall productivity growth and reducing regional disparities in productivity will depend on three key factors. First, reducing regulatory differences to create a uniform market will enable economies of scale and improve the efficiency of resource allocation. Second, increasing synergies between regions in terms of innovation policies, and the international exposure of lagging regions would make the environment conducive to productivity growth in lagging regions. Finally, low productivity growth, even in the most productive (frontier) regions, suggests that factors to enable the catch-up of Spanish firms to the international frontier, such as higher managerial quality and lower skill mismatch, are also important.

\section{Reducing regulatory differences}

Regulatory differences across regions can create implicit entry barriers, prevent economies of scale and agglomeration effects, via an effectively smaller market size and limit potential productivity gains. According to the Business Environment Survey, economic regulation is an important factor for firm growth capacity, especially for medium-sized companies (Figure ). Despite recent improvements to the economic regulatory environment, in 2017, only $6 \%$ of firms reported that the changes in economic regulations had a favourable impact on their business, while $17 \%$ affirm that the resources dedicated to red tape with all levels of government have increased. 
Figure 23. Economic regulation is relevant for firm growth

A. Percentage of firms that reported that the condition is an important factor for its growth, 2017

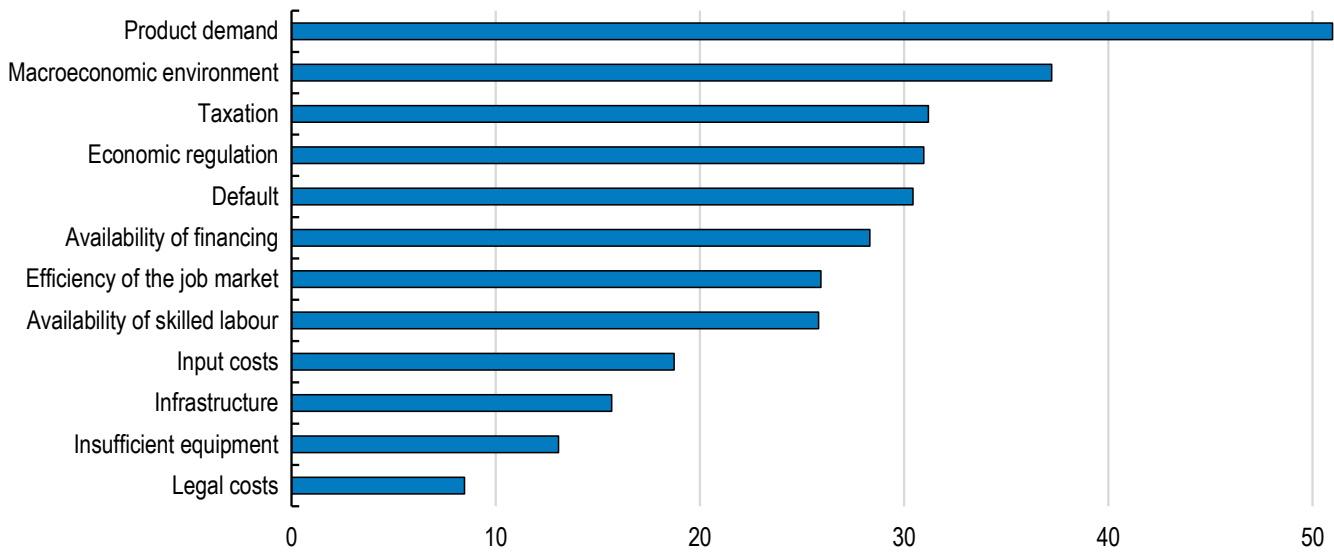

B. Percentage of firms that reported that economic regulation is of great importance, by firm size

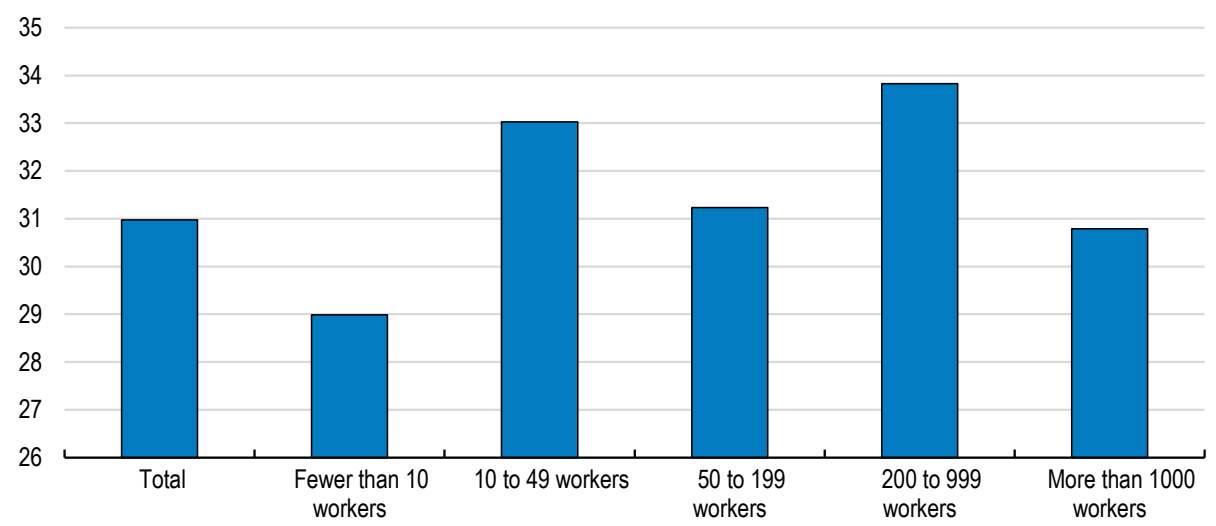

Source: INE, Business Environment Survey.

The Market Unity Law, which aims to tackle conflicts stemming from overlapping regulations, is a step in the right direction to create economies of scale. In 2017, the Constitutional Court declared that one of the main principles of the Law, that of national effectiveness, cannot be incorporated in national legislation due to the distribution of competences, while the other main principles remain intact. The principle of national effectiveness implies that economic agents in a region will not be subject to any requirements different than those they are already subject to in their region of origin.

It is important to continue to implement the remaining principles of the Market Unity Law and increase its transparency, and avoid creating uncertainty about the economic environment. The authorities estimate that the removal of the national effectiveness principle may have a cost of $0.7 \%$ and $0.9 \%$ on GDP and employment, respectively (Government of Spain, 2018). This legal principle could still be achieved, if incorporated in regional legislation. Some regions have already included this principle in their sectorial legislation, which is seen as an example of good practice for the application of the Market Unity Law (Secretaría del Consejo para la Unidad de Mercado, 2017). Cooperation across different levels of government must also be enhanced to guarantee the effective implementation of the Law. 
The central government has the legal mandate to systematically analyse that any new law legislated by the central government does not violate the Market Unity Law. The requirement of such an impact analysis should be extended to existing laws. Furthermore, some regions (e.g. Madrid) have already introduced a similar mandate to assess the effects of their actions on the implementation of the Market Unity Law. The remaining regions should adopt a similar approach. Furthermore, complaints about possible violations of the Law have been uneven across regions, suggesting that information is disseminated better in some regions. Having an information campaign to raise awareness of the Law, could improve its implementation and start yielding results in terms of increased inter-regional activity of firms.

A 2015 Regional World Bank Doing Business study shows that there are significant regional differences according to four criteria: starting a business, dealing with construction permits, getting electricity and registering property. The ranking of regions across the different criteria vary, suggesting that there is room to adopt best performer's regulations, allowing lagging regions to catch up. For example, regions where it is easier to start a business tend to have higher enterprise birth rates, suggesting that moving to best practices can increase business dynamism (Figure). While having a high ratio of start-ups is desirable, it is also important to ensure an environment that allows innovative ones to survive. Hence, the harmonisation of ease of entry should be complemented by measures to facilitate the allocation of resources to most productive uses, as discussed below.

Figure 24. Barriers to starting a business and business birth rates at the regional level

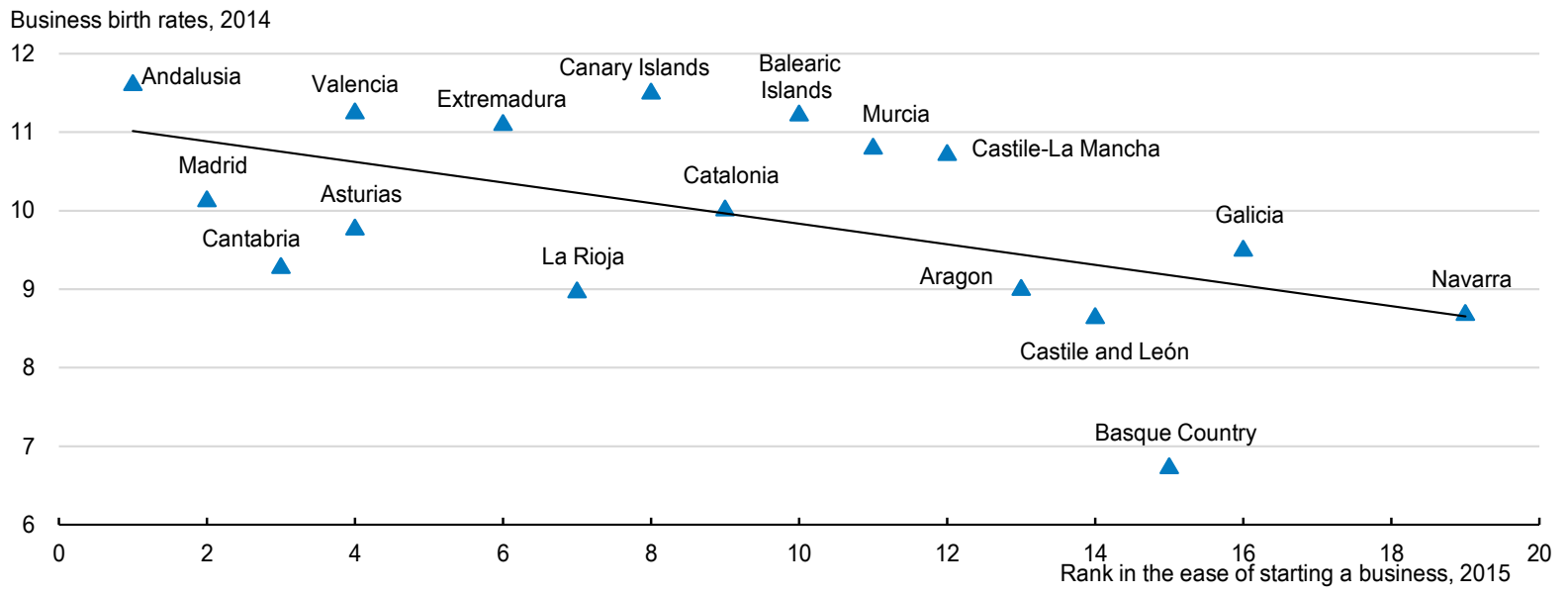

Source: World Bank, Doing Business Database and OECD, Regional Business Demography Database.

\section{Raising the ability of regions to benefit from spillovers}

Productivity growth, via more effective learning from the global frontier, is supported by a policy framework that promotes efficient resource allocation and is a positive function of its degree of international connectedness, ability to allocate skills efficiently and investments in knowledge based capital, including managerial capital and R\&D (Saia, Andrews and Albrizio, 2015). Spain lags behind in a number of these structural factors and policies, including skill mismatches, managerial quality and innovation policies (Figure ). An analysis of the catch up of lagging firms in Spain to the national productivity frontier shows that firms that are located in regions with greater trade intensity, higher R\&D expenditures and share of highly educated workers tend to experience faster rates of productivity growth (Box 1.5). 


\section{Box 5. Firm productivity convergence in Spain}

To examine whether lagging firms in Spain catch up to the national productivity frontier, a model is estimated where a firm's productivity growth depends on its distance to the productivity frontier, that is, the size of the gap between the productivity of a laggard firm and that of the productivity frontier for its industry, and the growth of the productivity frontier (Law, 2018). Specifically:

$$
\Delta \ln M F P_{i j t}=\alpha+\beta_{1} \ln \left(\frac{M F P_{j}^{F}}{M F P_{i}}\right)_{t-1}+\beta_{2} \Delta \ln M F P^{F}{ }_{j t}+\delta_{j}+\delta_{t}+\epsilon_{i j t}
$$

where $i$ refers to firms, $j$ refers to industry and $t$ refers to time. MFP and MFPF denote the multifactor productivity levels of non-frontier (laggard) firms and frontier firms in an industry, respectively. Time and industry fixed effects are captured by $\delta_{t}$ and $\delta_{j}$. $\beta_{1}$ measures the speed of productivity convergence and will be positive if the productivity growth of laggard firms is faster than the productivity growth of firms at the frontier. The model is also extended to include firm characteristics (age and size) as well as regional characteristics (trade intensity, the share of highly educated workers and the ratio of R\&D expenditures to regional GDP).

Table 2. Catch up to the national productivity frontier

Dependent variable: Firm MFP growth, 2000-15

\begin{tabular}{|c|c|c|c|c|}
\hline VARIABLES & (1) & (2) & (3) & (4) \\
\hline Distance to frontier & $\begin{array}{c}0.33539^{\star * *} \\
(0.000)\end{array}$ & $\begin{array}{c}0.21096^{\star * *} \\
(0.000)\end{array}$ & $\begin{array}{c}0.34097^{\star * *} \\
(0.000)\end{array}$ & $\begin{array}{c}0.21720^{\star \star *} \\
(0.001)\end{array}$ \\
\hline Change in the frontier & $\begin{array}{c}0.47660^{\star * *} \\
(0.005)\end{array}$ & $\begin{array}{c}0.44522^{\star * *} \\
(0.005)\end{array}$ & $\begin{array}{c}0.48335^{\star \star *} \\
(0.005)\end{array}$ & $\begin{array}{c}0.44506^{\star * *} \\
(0.005)\end{array}$ \\
\hline Lag of MFP growth & & $\begin{array}{c}-0.23272^{* * *} \\
(0.001)\end{array}$ & & $\begin{array}{c}-0.22932^{* * *} \\
(0.001)\end{array}$ \\
\hline Lag of change in the frontier & & $\begin{array}{c}0.02412^{\star * *} \\
(0.005)\end{array}$ & & $\begin{array}{c}0.01661^{* * *} \\
(0.005)\end{array}$ \\
\hline Firm age & & & $\begin{array}{c}0.00220^{* * *} \\
(0.000)\end{array}$ & $\begin{array}{c}0.00124^{* * *} \\
(0.000)\end{array}$ \\
\hline Firm size & & & $\begin{array}{c}0.00220^{* * *} \\
(0.000)\end{array}$ & $\begin{array}{c}0.00014^{* * *} \\
(0.000)\end{array}$ \\
\hline Trade intensity & & & $\begin{array}{c}0.00074^{* * *} \\
(0.000)\end{array}$ & $\begin{array}{c}0.00048^{* * *} \\
(0.000)\end{array}$ \\
\hline Share of highly educated in employment & & & $\begin{array}{c}0.00209^{* * *} \\
(0.000)\end{array}$ & $\begin{array}{c}0.00159^{* * *} \\
(0.000)\end{array}$ \\
\hline Share of R\&D in GDP & & & $\begin{array}{c}0.01167^{* * *} \\
(0.001)\end{array}$ & $\begin{array}{c}0.00654^{* * *} \\
(0.001)\end{array}$ \\
\hline Industry Fixed Effects & YES & YES & YES & YES \\
\hline Year Fixed Effects & YES & YES & YES & YES \\
\hline SDBS Weights & YES & YES & YES & YES \\
\hline Observations & $4,273,249$ & $3.362,724$ & $4,008,123$ & $3,533,941$ \\
\hline AdjR2 & 0.1369 & 0.1465 & 0.1367 & 0.1478 \\
\hline
\end{tabular}


Results suggest that laggard firms, on average, converge to their respective industries' productivity frontier. In addition, older and larger firms tend to experience faster rates of productivity growth, in line with cross-country studies (Andrews, Criscuolo and Gal, 2015). Laggard firms in regions with higher trade intensity, R\&D expenditures and share of highly educated workers also have higher productivity growth (Table ).

Figure 25. Factors and policies to boost spillovers from the frontier

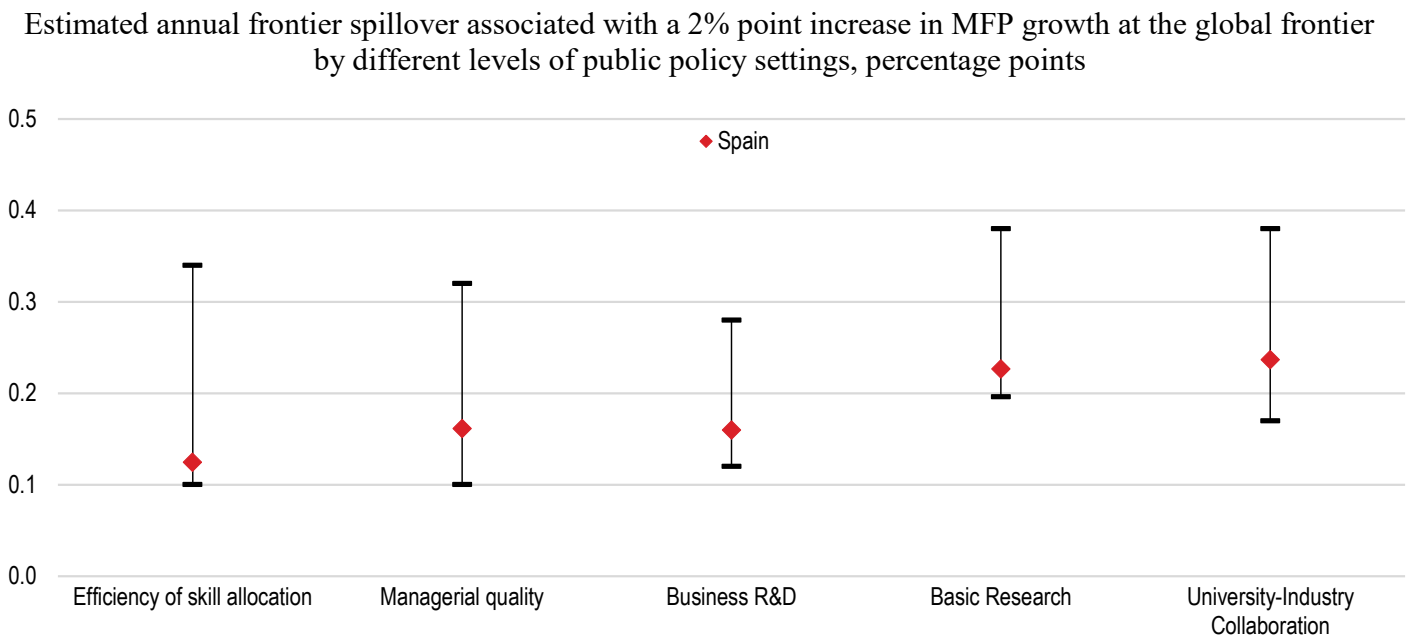

Notes: The chart shows how the sensitivity of MFP growth to changes in the frontier growth varies with different levels of each variable. The diamond refers to the estimated frontier spillover effect associated with a $2 \%$ MFP growth at the frontier for Spain. The range indicates the country with the lowest (highest) value for the given structural variable or policy in a given reference year.

Source: OECD calculations based on Saia et al. (2015).

\section{Improving allocation of resources}

A dynamic economy needs the ability to reallocate resources from less to more productive firms and from declining to growing industries, but studies have highlighted the importance of resource misallocation as a source of the productivity slowdown, especially in Spain (Gopinath et al., 2017; Gamberoni, Giordano and Lopez-Garcia, 2016; García-Santana et al., 2016). Recent OECD analysis suggests that the decline in the efficiency of labour allocation in Spain during the crisis disproportionately affected young firms (Box 1.6). Such misallocation of resources might have lowered business dynamism and contributed to the low dynamism of even frontier firms and regions.

One measure of low efficiency of resource allocation is the share of zombie firms, defined as firms older than ten years which persistently fail to cover their interest payments from current earnings for three consecutive years. According to the Bank of Spain, the share of zombie firms has declined from $10 \%$ in 2013 to $7 \%$ in 2016, partly driven by the cyclical recovery. Insolvency reform reducing barriers to firm exit and restructuring has also contributed (Adalet McGowan, Andrews and Millot, 2017). Nevertheless, empirical analysis suggests that even controlling for cyclical factors, zombie firms can be a barrier to the growth of more productive firms in Spain (Adalet McGowan and Antona San Millán, 2018). Furthermore, the prevalence of zombie firms displays some regional differences, which could be expected given the heterogeneity of region-specific regulations and labour market outcomes (Figure, Panel A). It could also reflect regional differences in the 
efficiency of the judicial system which could yield uneven results in the implementation of insolvency reform across regions (García-Posada and Mora-Sanguinetti, 2015).

\section{Box 6. Resource misallocation in Spain}

To test the sensitivity of firm employment growth with respect to lagged firm MFP, we estimate the following model:

$$
\begin{aligned}
& \text { Employment growt }_{\text {ist }}=\alpha+\beta_{1} M F P_{\text {ist }-1}+\beta_{2} M F P_{\text {ist }-1} * \text { Trend }_{t}+ \\
& \beta_{3} M F P_{\text {ist-1 }} * \text { TrendS }_{t}+\beta_{4} \text { Firm controls }_{\text {ist }-1}+\delta_{s}+\delta_{t}+\epsilon_{\text {ist }}
\end{aligned}
$$

where employment growth is the change in employment for firm $i$, in industry $s$, at time $t$; MFP denotes a measure of firm-level multifactor productivity which is a deviation from the industry-year average to control for MFP differences across industries; trend is a simple linear time trend and trendSQ is a quadratic trend; firm controls include dummies for firm age $(Y O U N G=1$ if age $<6$ ) and firm size.

The baseline analysis shows that firms with higher than average productivity are able to attract more labour, indicating resource reallocation is - on average - productivityenhancing in Spain (Adalet McGowan and Antona San Millán, 2018). The interaction terms of lagged firm MFP with the trend and trend square capture the variation in the responsiveness of labour to firm productivity over time. Differentiating between the effect of labour misallocation according to firm age (via interacting the main variables with a young or mature dummy) shows that young firms disproportionately suffered from misallocation of labour, during the crisis, although this trend is reversing (Table ).

Table 3. Labour misallocation according to firm age

\begin{tabular}{|c|c|c|}
\hline VARIABLES & (1) & $(2)$ \\
\hline $\mathrm{MFP}_{\mathrm{t}-1} \mathrm{X}$ YOUNG & $\begin{array}{c}0.08813^{* * *} \\
(0.001)\end{array}$ & $\begin{array}{c}0.10251^{\text {*** }} \\
(0.003)\end{array}$ \\
\hline MFP $_{\mathrm{t}-1} \mathrm{X}$ Time Trend $\mathrm{X}$ YOUNG & & $\begin{array}{c}-0.00285^{\text {*** }} \\
(0.001)\end{array}$ \\
\hline $\mathrm{MFP}_{\mathrm{t}-1} \mathrm{X}$ Time Trend Squared X YOUNG & & $\begin{array}{c}0.00012^{* * *} \\
(0.000)\end{array}$ \\
\hline MFP $_{\mathrm{t}-1} \mathrm{X}$ MATURE & $\begin{array}{c}0.08307^{* * *} \\
(0.000)\end{array}$ & $\begin{array}{c}0.08750^{* * *} \\
(0.002)\end{array}$ \\
\hline $\mathrm{MFP}_{\mathrm{t}-1} \mathrm{X}$ Time Trend X MATURE & & $\begin{array}{c}0.00175^{\star * *} \\
(0.000)\end{array}$ \\
\hline MFP $_{\mathrm{t}-1} \mathrm{X}$ Time Trend Squared X MATURE & & $\begin{array}{c}-0.00016^{* * *} \\
(0.000)\end{array}$ \\
\hline Firm age and size controls & YES & YES \\
\hline Industry Fixed Effects & YES & YES \\
\hline Year Fixed Effects & YES & YES \\
\hline Observations & $5,287,269$ & $5,287,269$ \\
\hline AdjR2 & 0.0539 & 0.0541 \\
\hline
\end{tabular}

Dependent variable: employment growth, 1998-2014 
Figure 26. Resource misallocation is heterogeneous across Spanish regions

A. Zombie fims as a share of all firms in the region, 2013

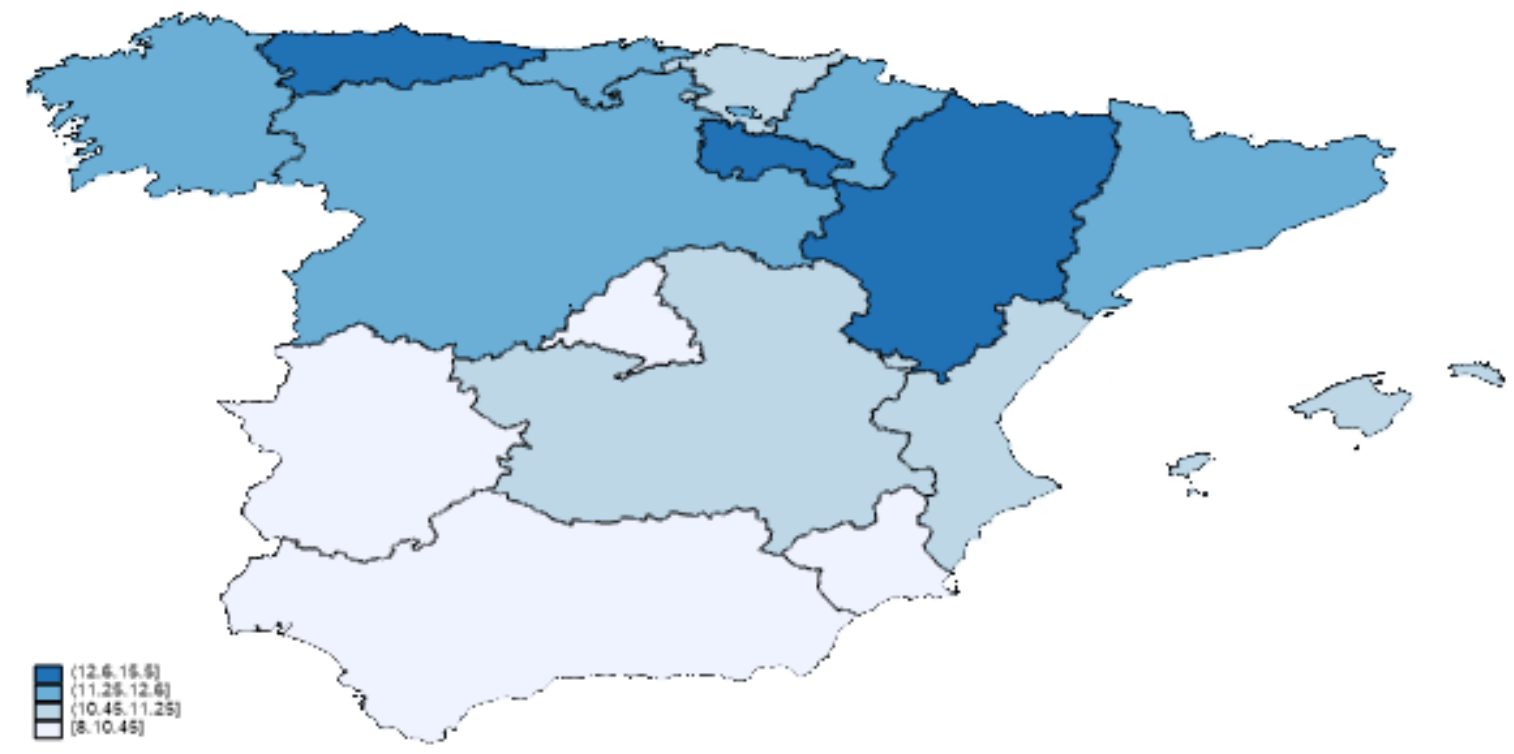

B. Re gional product trity and skil mis match are negatively correlated

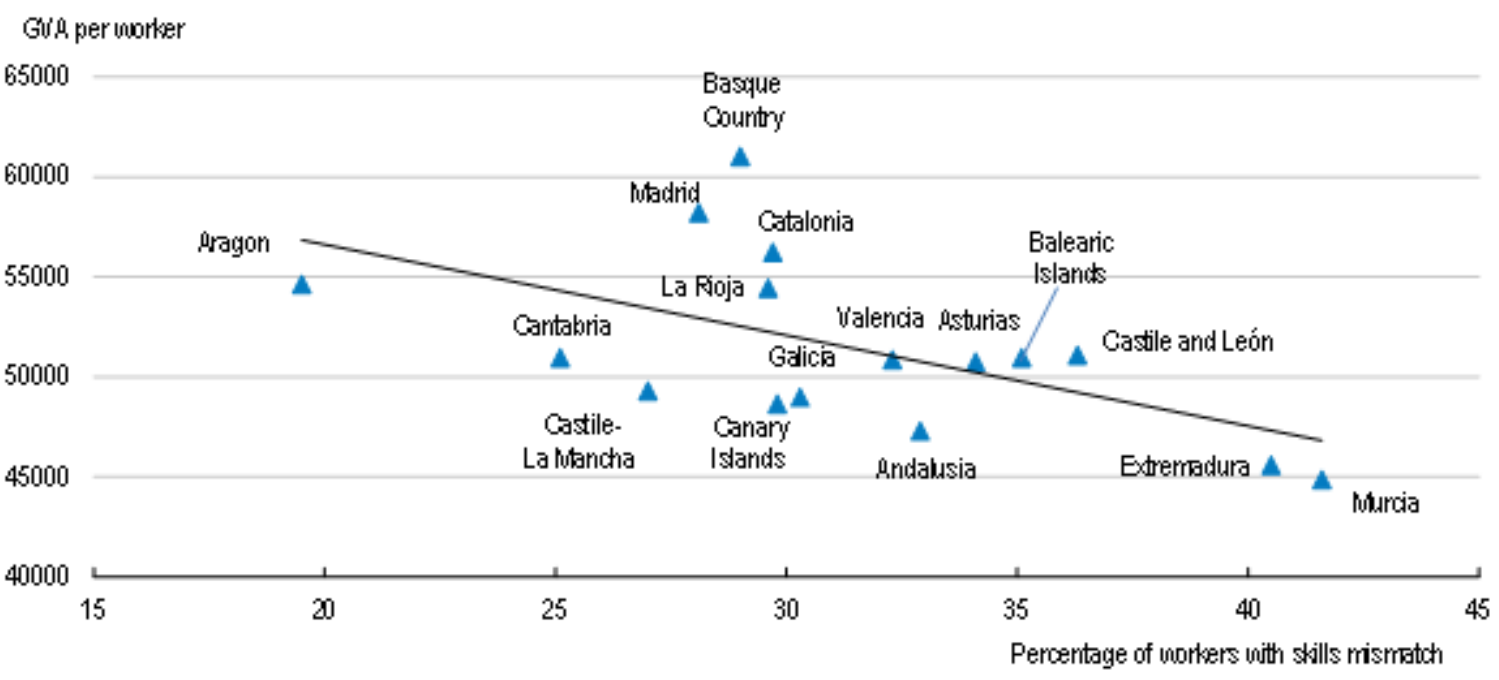

Note: Panel A: A darker shade corresponds to a higher value. Panel B: It should be noted that OECD, Survey of Adult Skills is not completely representative across regions and the results on skill mismatch should be taken with some caution.

Source: Calculations based on ORBIS, OECD Survey of Adult Skills and OECD, Regional Database.

Skill mismatch, another measure of labour misallocation, is also heterogeneous across Spanish regions, with potential implications for regional productivity (Figure, Panel B). A number of policies can address skill mismatches. For example, higher investment in managerial skills can lower skill mismatch as better managers will be more effective at matching the competencies of a worker to those required by a job, developing new work practices to more effectively integrate new technologies, internally reallocating mismatched workers to different positions or sending them to training. 
The World Management Survey ranks Spain relatively low in terms of managerial quality, especially for small firms. Higher managerial quality in large firms can lower skill mismatches by ensuring that under-skilled workers get the right training. Indeed, in 2016, only $29.4 \%$ of firms with between 5 and 9 workers detected training needs among employees, compared to $87.7 \%$ of firms with more than 499 workers (Ministry of Employment, 2016). Good managerial practices would be diffused more effectively by lowering barriers to the mobility of talented managers within the labour market and encouraging skilled immigration. Reforms that increase competitive pressures, as discussed above, would also increase managerial quality.

High-performance work practices (HPWP), which include work organisation, such as team work, autonomy, job rotation and applying new learning and management practices such as training practices and flexibility in working hours, are linked to high skill use in the workplace (OECD, 2016e), but the share of jobs with HPWP is relatively low in Spain (Figure 27). Policies that have been successfully used to stimulate the use of HPWP such as attributing (competitive) grants to assist (targeted) firms with their implementation as in New Zealand and the Netherlands, developing business coaching programmes for SMEs (New Zealand), or supporting the establishment of management and entrepreneurs' networks to disseminate the adoption of good practices as in Finland could be considered (OECD, 2016e).

Figure 27. The share of jobs with high-performance workplace practices is low

Share of jobs with high HPWP and mean HPWP score

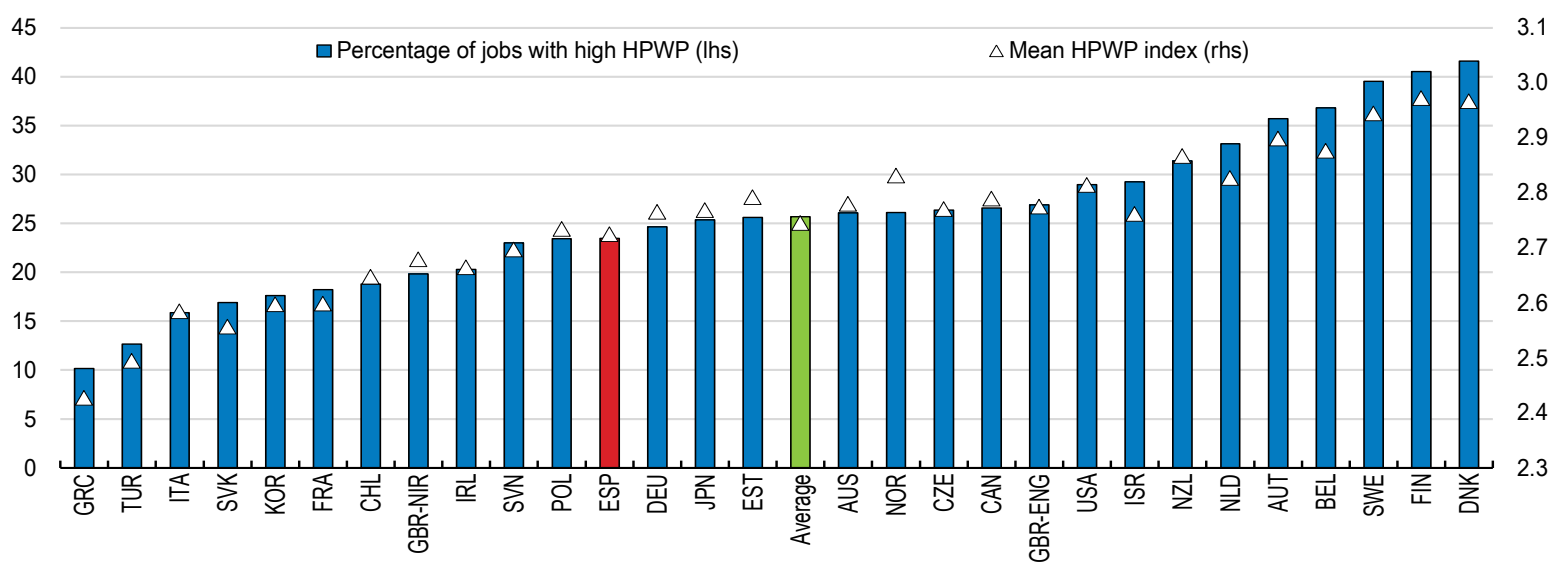

Note: High Performance Work Practices (HPWP) include aspects of work organisation (team work, autonomy, task discretion, mentoring, job rotation, applying new learning) and management practices (employee participation, incentive pay, training practices and flexibility in working hour). High HPWP refers to when the HPWP is above the top 25 th percentile of the pooled distribution.

Source: OECD (2016), Employment Outlook.

\section{Enhancing innovation performance}

Gross domestic expenditures on R\&D relative to GDP is low in Spain at around half the OECD average and business R\&D investment at $0.6 \%$ in 2016 is well below the OECD average of $1.6 \%$. Furthermore, Spain experienced one of the largest reductions in government funding for R\&D among OECD countries over the period 2008-15, with a decline of nearly $30 \%$ in real terms (OECD, 2017g). Another issue is low levels of execution of some parts of the public R\&D budgets, due to limited demand from private firms and complex management procedures. 
The innovation performance of the Spanish business sector still lags behind the OECD and the EU median in several dimensions, such as patenting and R\&D activity. Going forward, a critical challenge for improving competitiveness and economic growth and drawing more benefits from globalisation will be improving the innovation capacity of the business sector and the general innovation framework. This requires effective policies at the regional level. Indeed, there is evidence that regional factors such as the degree of cooperation and the skill of the labour force affect the innovation and exporting performance of firms (LópezBazo and Motellón, 2013a and 2013b). Recent evidence suggests the economic crisis limited the ability of regional innovation policies to boost business R\&D investment (CruzCastro et al., 2018).

An important feature of innovation in Spain is the role of regions in innovation policy and its heterogeneous performance (Table ). R\&D funding and innovation performance is a shared competence between regions and the central government, which increases the importance of coordination for successful outcomes. Around $40 \%$ of patents and business expenditure are concentrated in the top $20 \%$ of regions. While concentration of innovation activity is expected in more productive regions, it could limit the ability of firms to adopt new and existing technologies from regional and national frontier firms. For example, evidence from the United Kingdom shows that investing in R\&D can lift the productivity of lagging regions (Kierzenkowski, Gal and Fulop, 2017).

Table 4. Regional innovation performance

\begin{tabular}{|c|c|c|c|c|c|c|c|c|}
\hline & $\begin{array}{c}\text { R\&D } \\
\text { expenditure } \\
\text { (\% of GDP), } \\
2013\end{array}$ & $\begin{array}{l}\text { Business } \\
\text { R\&D (\% of } \\
\text { GDP), } \\
2013\end{array}$ & $\begin{array}{c}\text { Higher } \\
\text { education } \\
\text { R\&D (\% of } \\
\text { GDP), } \\
2013\end{array}$ & $\begin{array}{l}\text { R\&D } \\
\text { personnel (\% } \\
\text { of total } \\
\text { employment), } \\
2013\end{array}$ & $\begin{array}{l}\text { Share of } \\
\text { labour } \\
\text { force with } \\
\text { tertiary } \\
\text { education, } \\
2014\end{array}$ & $\begin{array}{l}\text { Employment } \\
\text { in knowledge } \\
\text { intensive } \\
\text { services ( } \% \\
\text { of total } \\
\text { employment), } \\
2014\end{array}$ & $\begin{array}{c}\% \text { of } \\
\text { innovating } \\
\text { firms, } \\
2014-16\end{array}$ & $\begin{array}{c}\text { GVA } \\
\text { per } \\
\text { worker, } \\
2015\end{array}$ \\
\hline Andalusia & 1.0 & 0.4 & 0.4 & 1.6 & 29.7 & 34.9 & 25.1 & 65536 \\
\hline Aragon & 0.9 & 0.5 & 0.2 & 1.8 & 38.3 & 33.9 & 30.1 & 75690 \\
\hline Asturias & 0.9 & 0.5 & 0.3 & 1.8 & 44.6 & 35.3 & 24.5 & 70316 \\
\hline Balearic Islands & 0.3 & 0.0 & 0.2 & 0.7 & 29.3 & 31.6 & 22.5 & 70602 \\
\hline Basque Country & 2.1 & 1.6 & 0.4 & 3.3 & 51.3 & 37.0 & 29.7 & 84548 \\
\hline Canary Islands & 0.5 & 0.1 & 0.2 & 0.8 & 29.2 & 32.1 & 25.5 & 67395 \\
\hline Cantabria & 0.9 & 0.3 & & 1.6 & 41.4 & 36.0 & 20.9 & 70595 \\
\hline Castile and León & 1.0 & 0.6 & 0.3 & 1.8 & 37.0 & 34.4 & 25.5 & 70786 \\
\hline Castile-La Mancha & 0.5 & 0.3 & 0.2 & 0.8 & 30.0 & 35.3 & 23.7 & 68281 \\
\hline Catalonia & 1.5 & 0.9 & 0.4 & 2.3 & 39.4 & 35.4 & 32.9 & 77894 \\
\hline Extremadura & 0.8 & 0.2 & 0.4 & 1.2 & 29.8 & 36.9 & 23.4 & 63157 \\
\hline Galicia & 0.9 & 0.4 & & 1.8 & 37.2 & 33.7 & 27.5 & 67862 \\
\hline La Rioja & 0.8 & 0.4 & & 2.0 & 39.4 & 31.4 & 30.7 & 75421 \\
\hline Madrid & 1.8 & 1.0 & 0.3 & 2.8 & 49.0 & 47.7 & 31.1 & 80658 \\
\hline Murcia & 0.8 & 0.3 & 0.4 & 1.5 & 29.2 & 28.4 & 27.4 & 62160 \\
\hline Navarra & 1.8 & 1.2 & & 2.7 & 45.7 & 34.1 & 27.8 & 80766 \\
\hline Valencia & 1.0 & 0.4 & 0.5 & 1.7 & 33.6 & 30.5 & 32.3 & 70463 \\
\hline
\end{tabular}

Note: Top three regions in each category are shaded in blue. Gross value added (GVA) per worker is in thousand USD, constant prices, PPP.

Source: OECD, Regional Database.

The regions have a large role in designing and executing innovation policy, but innovation support is fragmented, which makes it harder for innovative firms to navigate the system and can lead to duplication (ERAC, 2014). The new National Plan for Science, Technology and Innovation 2017-20 combines information on all support schemes from different institutions, which can be a good starting point to make information on existing opportunities more transparent and more easily accessible. 
When developing a regional innovation strategy, regions should be aware of what the neighbouring regions are doing as inter-regional collaboration via complementary strategies could deliver additional knowledge spillovers (OECD, 2017h). Recent policies such as the reactivation of the R\&D Public Policy Network (REDIDI) to create synergies in the implementation of national and regional smart specialisation strategies are welcome. Efforts should continue to improve national and regional cooperation in the design and implementation of innovation policies to avoid duplication.

Improving the ex-ante and ex-post evaluation framework of research and innovation policies can help provide better incentives for research performance. At the national level, the new State Research Agency for managing research funding of some projects and human resource programs uses ex-ante evaluation. However, quality, impact and efficiency of all public funding of research are not systematically assessed with comparable methodologies, especially at the regional level (Fernandez-Zubieta, Ramos-Vielba and Zacharewicz, 2018). The Severo Ochoa Centres of Excellence and Maria de Maeztu Units of Excellence programmes are examples of good practice of international evaluation of funding programmes. To increase the efficiency of innovation spending and the quality of innovation, the ex-post evaluation framework should be strengthened and an increase in performance based funding of research should be considered. This should be complemented with encouraging greater scale and specialisation of universities and research organisations, by extending the application of international peer review and by providing more career opportunities for highly qualified researchers, as recommended in the 2014 Economic Survey of Spain.

Innovation cooperation across firms and between firms and research institutions can have positive externalities on firm innovation performance (Badillo and Moreno, 2014; D'Agostino and Moreno, 2017). Reinforcing policy instruments promoting cooperation between firms and research institutions and encouraging research commercialisation and technology transfer is key to boosting spillovers. With the rise of digitalisation, several OECD countries are encouraging the development of ICT clusters which facilitate scienceindustry interactions and interactions between industries and across regions (OECD, 2016f). In 2018, Spain Cluster, which will reinforce the role of business innovation in the era of digital transformation, will be launched. Ensuring that this initiative has a strong regional dimension could improve its effectiveness.

Although basic research results in significantly larger knowledge spillovers than applied research, private research effort is geared towards applied research, given that the output of basic research is freely available to the public (Akcigit, Hanley and Serrano-Velarde, 2013). Higher public spending on basic research enhances the ability of economies to learn from new innovations at the global frontier (Saia, Andrews and Albrizio, 2015), but basic research as a share of GDP at 0.27 in Spain is lower than the OECD average of 0.42 . Assuming a 2\% acceleration in MFP growth in the frontier economy, annual MFP growth is estimated to be around 1.5 percentage points higher in Spain, if it increased its share of basic research to $0.5 \%$ of GDP (Figure ). Hence, it is also important to ensure that innovation policies do not favour applied research over basic research.

\section{Boosting international spillovers}

International exposure can enhance the capacity of economies to capitalise on new technologies developed abroad, learn from the global frontier and can be shaped by a number of factors such as exposure to trade and FDI and migration (OECD, 2015). For example, Spanish firm-level studies show that the impact of cooperation on innovation 
performance with external partners is larger than national ones, indicating that firms tend to benefit more from interaction with international partners as a way to access new technologies (Badillo and Moreno, 2014). However, international cooperation is low in Spain (OECD, 2017g).

Greater regional participation in global value chains (GVCs) can help address disparities both in employment and productivity. GVC integration varies strongly across regions in OECD countries, with the share of value-added produced within GVCs as a share of total value added fluctuating by around 10 percentage points across regions within a country. The variation is especially large in Spain (OECD, 2018a). Recent OECD evidence suggests that greater integration of regional economies into GVCs is associated with an increase of regional productivity and employment rates (OECD, 2017d). Hence, policies to increase internationalisation of Spanish firms can help boost productivity.

While some type of specialisation across regions is necessary to achieve economies of scale and exploit comparative advantage, regions can benefit from greater exposure to international factors. This is especially important given that Spanish frontier firms are lagging significantly behind global frontier ones. The exposure of regions to international factors varies across a number of dimensions such as manufacturing as a share of GDP, trade as a share of GDP, GVC participation, the share of foreign students and the share of international co-patenting (Figure). In 2017, an internationalisation strategy was developed at the national level in consultation with regions and the private sector. Regions should use this framework to follow best practices and exploit their unique strengths.

Figure 28. Regions have different strengths in terms of exposure to international factors

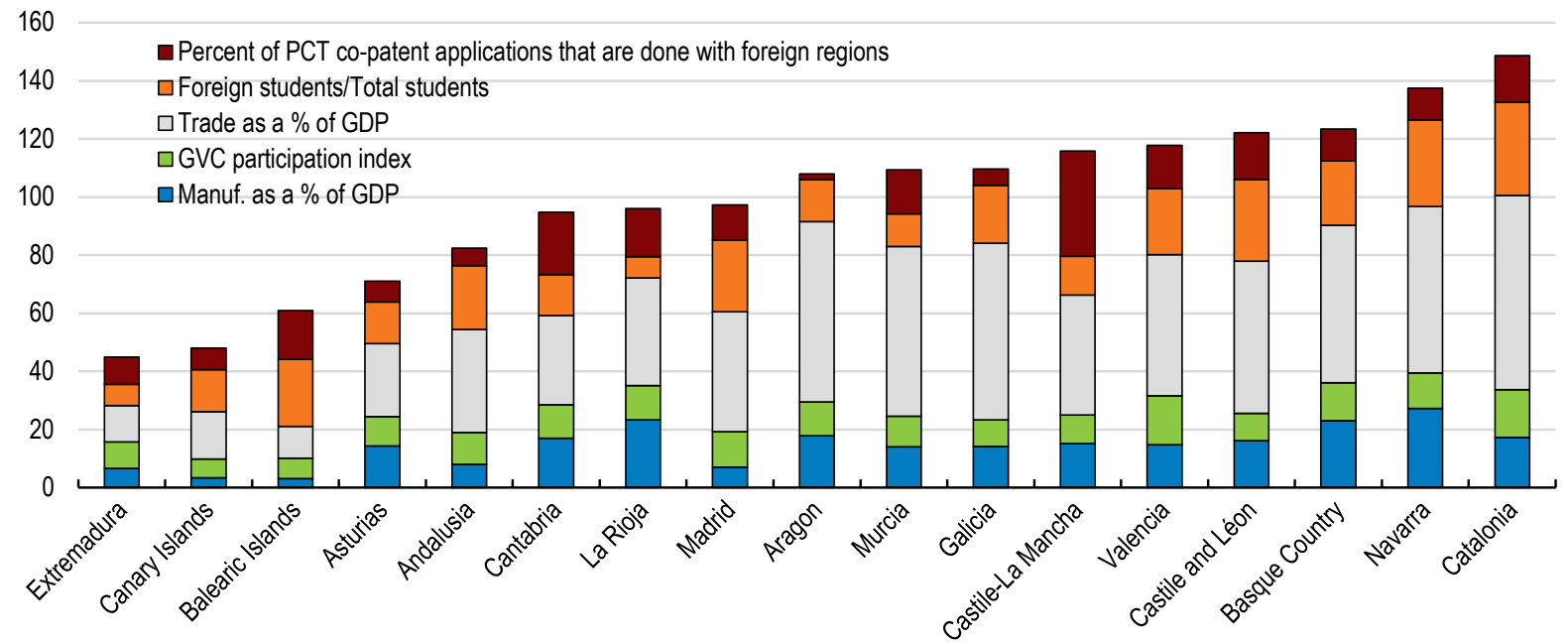

Note: Data refer to 2011, 2015 or 2017, depending on the variable.

Source: OECD, Regional Database, Ministry of Education and INE. GVC calculations based on data provided by Los, B. and W. Chen (2016), "Global Value Chain Participation Indicators for European Regions", Report for the OECD, No. December 2016. See Thissen, Lankhuizen and Los (2017) for details.

\section{Getting the most out of decentralisation}

Decentralisation can have an effect on economic activity and well-being through a number of channels. A high degree of decentralisation, if well-designed with a clear and balanced assignment of responsibilities, can help ensure that resources are utilised efficiently to meet local needs (OECD, 2016g). However, the lack of consistent and reliable information on 
regional policies and outcomes, effective coordination mechanisms across different levels of government and evaluation systems can reduce the benefits of decentralisation. The ability of regions to implement policies effectively to reduce regional disparities will also depend on their fiscal position.

\section{Improving evaluation, coordination and sharing of best practices}

The government recently announced allocation of funds to regional employment offices based on evaluations according to pre-defined performance indicators to improve the effectiveness of ALMPs (see above). It would be useful to extend policy evaluation at the regional level to other areas. As lagging regions might not always have the resources or expertise to evaluate the implementation of their policies, this would require greater interregional cooperation. While there are some informal arrangements already in place, the creation of an independent National Evaluation Agency, which would regularly evaluate regional policies, identify best practices and provide policy guidance for adoption in other regions, could be considered to boost domestic spillovers.

A greater use of benchmarking of services could also create competitive pressures and improve the quality of services provided at the regional level, especially given low geographical mobility in Spain. In decentralised countries, benchmarking is more likely to be successful, if it is collaborative rather than based on "naming and shaming" and if it is complemented by information sharing (Phillips, 2018).

There is room to improve the utilisation of sectoral conferences by increasing their synergies with the proposed improvements to evaluation and sharing of best practices. Sectoral conferences are the most important policy coordination tool across government levels in Spain, which bring together regional authorities and the central government ministry for a given area (OECD, 2017i and 2017j). One of the main aims of the Reform of the Spanish Public Administration (CORA) in 2012 was to eliminate overlap between different levels (central, regional, local) of the Spanish public administration. This has delivered good results in some areas. For example, coordination in the area of health was enhanced via an e-health system and the creation of a health card database (OECD, 2016h). While some regional disparities in health outcomes remain, these are small in international perspective (OECD, 2016b).

\section{Strengthening the fiscal framework and rules}

The outcomes of decentralisation in terms of growth, inclusiveness and fiscal performance depend on the design of the various fiscal federalism features, their implementation and on subnational capacity (OECD, 2018e). In this context, reforming the regional financing system, increasing the consistency of fiscal rules and dealing with the regional debt legacy from the crisis are key in Spain.

\section{High degree of fiscal decentralisation}

Spain is a highly decentralised country in terms of expenditures and revenues. In 2016, regional and local government expenditures as a share of total general government spending stood at $43 \%$ (Figure, Panel A). At around 28\%, decentralisation in terms of revenues is high in international comparison, though it is lower than decentralisation in terms of spending - as is the case in most countries (Figure, Panel B). Regions receive a certain percentage of revenues collected: $50 \%$ of the personal income tax and $50 \%$ of valueadded tax revenues, 58\% of excise taxes on tobacco, alcohol and petrol and $100 \%$ of revenues from the tax on electricity and certain means of transport. They have autonomy 
over the wealth tax, inheritance and gift tax, tax on capital transfers, gambling tax and vehicle excise tax.

Figure 29. Distribution of expenditures and revenues across levels of government

\section{A. Expenditures}

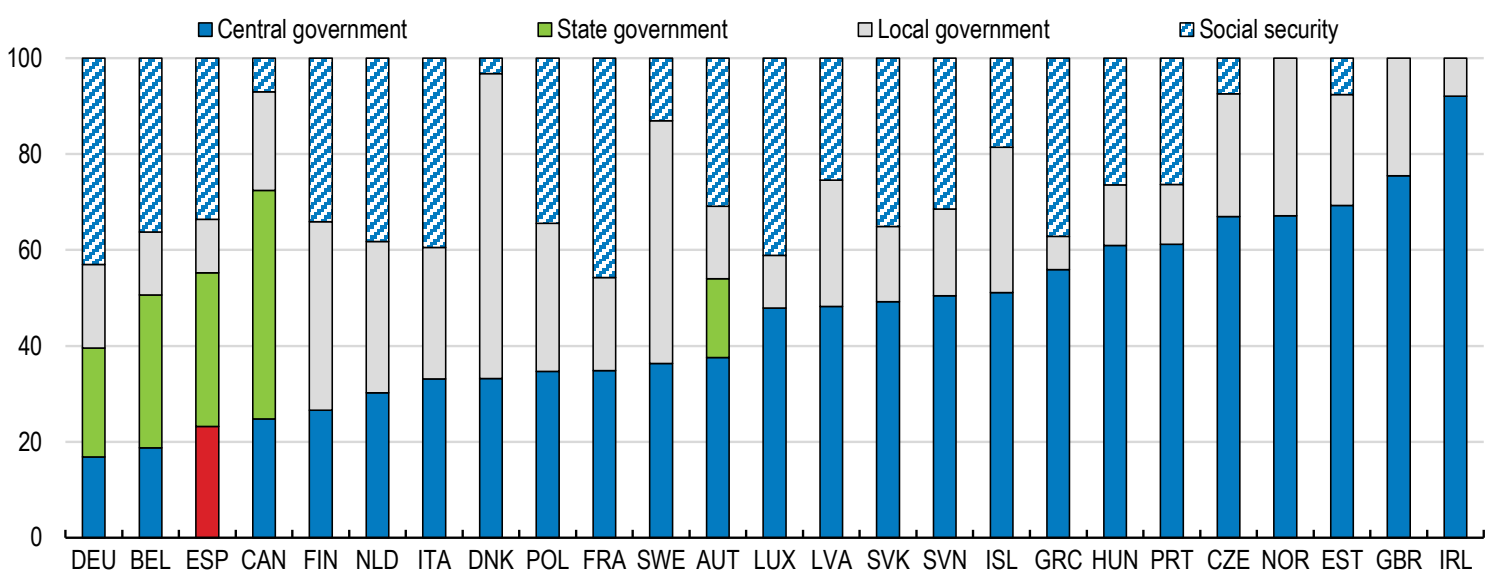

B. Revenues

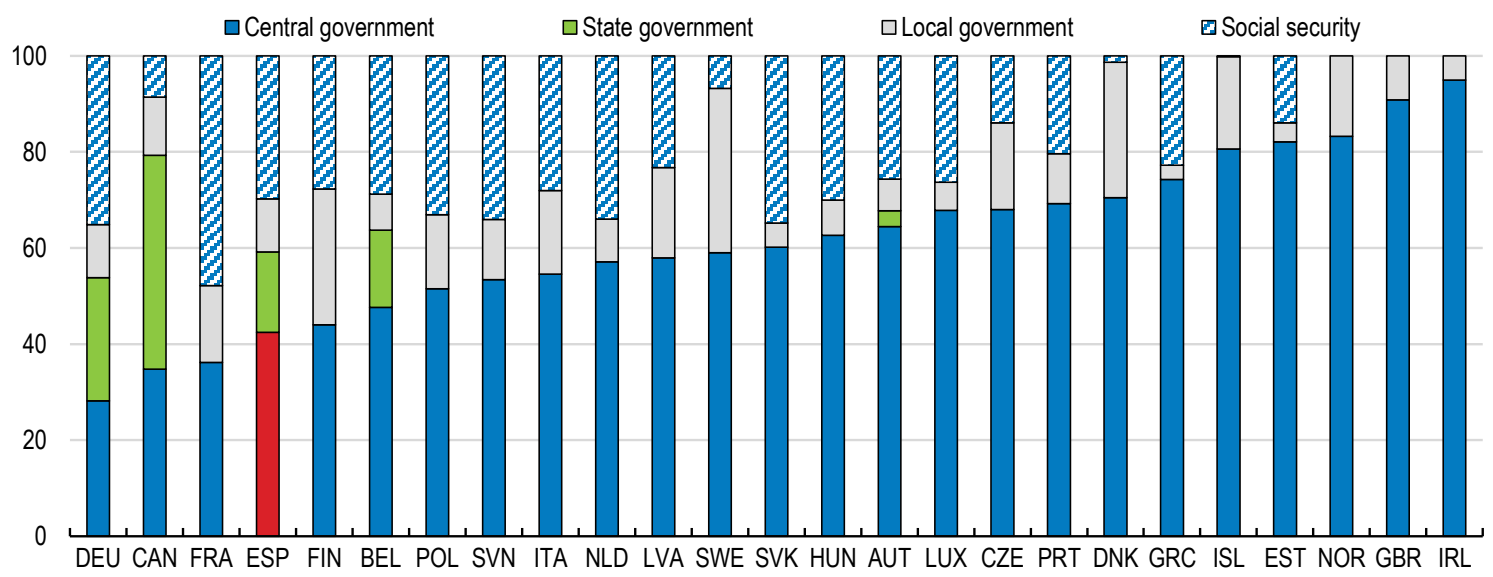

Note: The revenues data exclude transfers between levels of government in order to see the contribution of each sub-sector in general government total revenues, which are consolidated at this level. However, data on the structure of revenues at the central, state and local levels include transfers between levels of government. Source: OECD (2017), Government at a Glance 2017 (database).

Regional governments are responsible for a number of expenditures, such as healthcare and education, whose benefits go beyond local needs, highlighting the importance of efficiency of spending at the regional level, but also co-responsibility across levels of government (Figure, Panel A). Regional governments also account for a large percentage of government employees and public procurement (Figure, Panels B and C). Hence, they can affect competition and labour markets, for example, by setting wage levels that reflect regional conditions and needs. Finally, sub-national governments carried out $68 \%$ of public investment in 2016 (Figure, Panel D). 
Figure 30. Responsibilities of regional governments are large in some areas
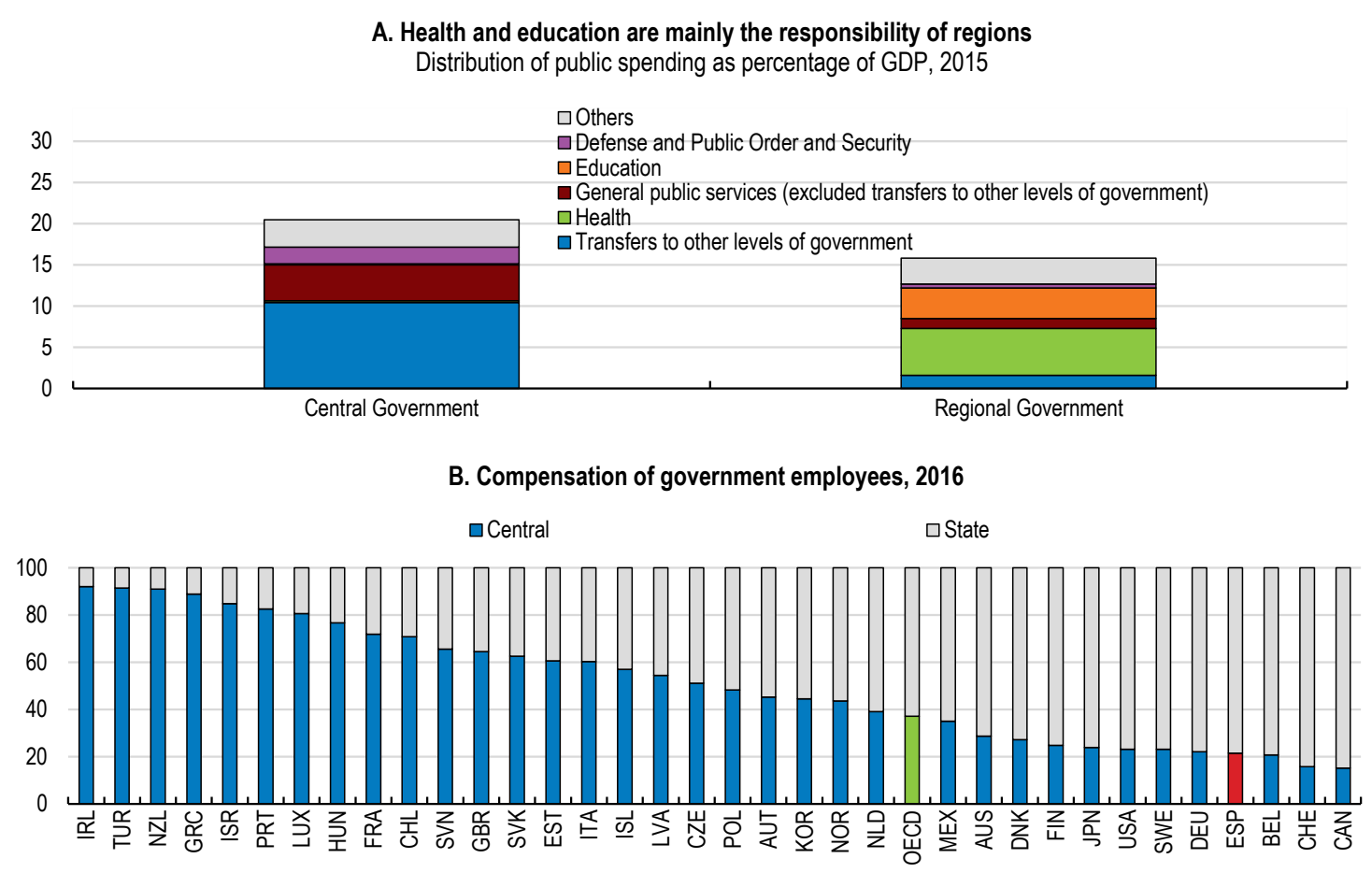

C. Government procurement as a share of total public procurement, 2016

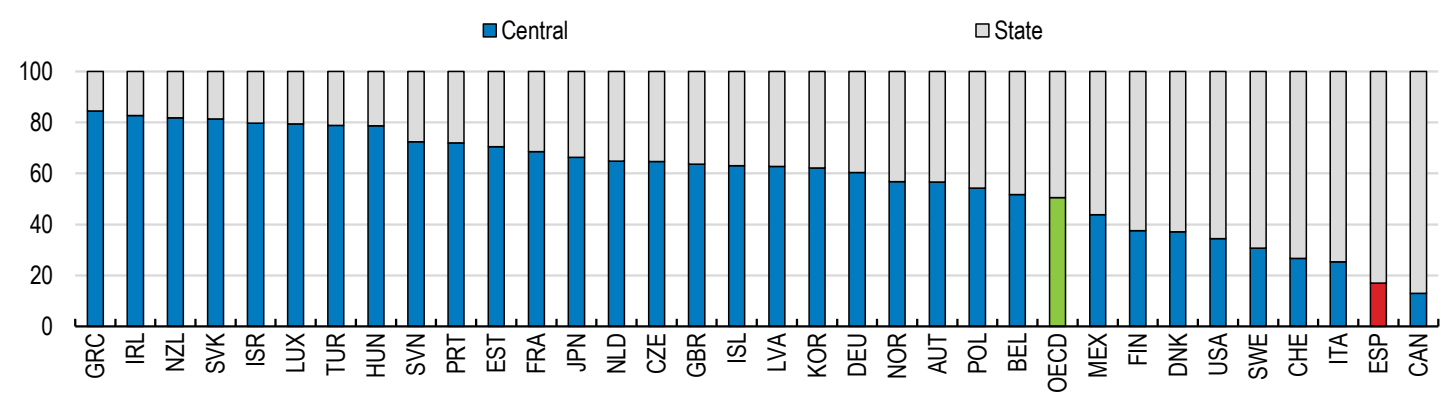

D. Government investment as a share of total investment, 2016

$\square$ Central 口Local \& State

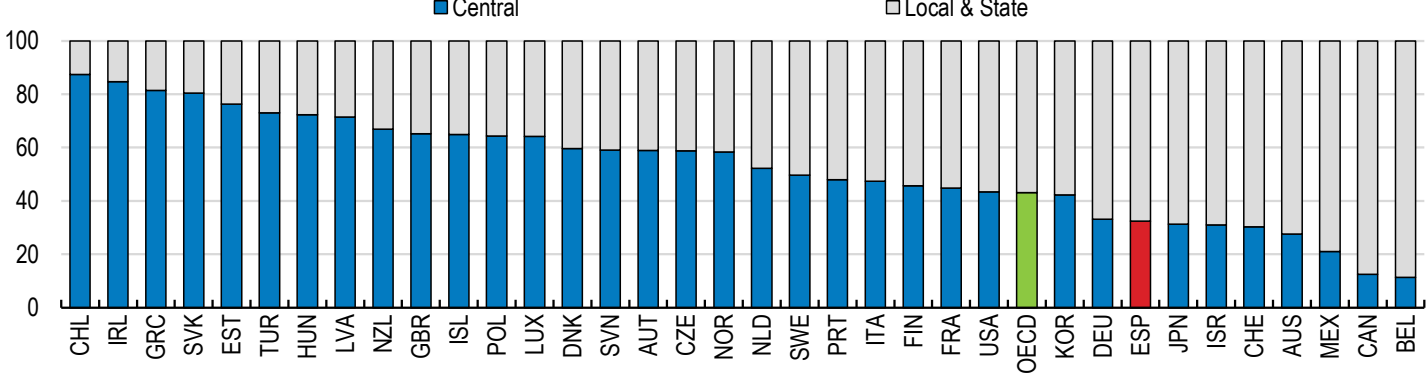

Source: The General Comptroller of the State Administration (IGAE), OECD (2018), Subnational governments in OECD countries: Key data (brochure).

\section{Reforming the regional financing system}

The regional financing system is based on the principles of tax autonomy, co-responsibility, sufficiency and solidarity. The common system applies to all regions except Navarra and the Basque Country, which have the foral system, giving them a higher degree of 
autonomy, including in revenue collection. Co-responsibility is achieved through tax autonomy, while the solidarity principle through equalisation transfers to ensure that each region receives the same resources relative to its adjusted population. The sufficiency principle requires that all regions have sufficient resources to deliver services with a minimum level of quality. The system was reformed in 2009, partly to address asymmetric shocks due to population growth (Box 7) (OECD, 2012b).

\section{Box 7. Reform of the regional financing system in 2009}

The reform consisted of the following elements:

Reform of the equalisation system: The new system provides partial equalisation via different funds (see below). The regions' needs are now re-evaluated and adjusted yearly, following the evolution of actual needs (mainly in response to population changes), and thus ultimately adjusting the regions' relative shares.

Creation of four specific funds: The Fund to Guarantee Public Services is divided among the regions according to adjusted population criteria, i.e. population weighted by age group, area of the region, dispersion of the population in the region, island status, etc. This fund is adjusted yearly, taking into account the evolution of these variables. The Global Sufficiency Fund provides sufficient resources for the rest of the devolved responsibilities, and guarantees that there are no net losers due to the reform. The Competitiveness Fund allocates resources to those regions whose funding per head is under the national average or their fiscal capacity. The Cooperation Fund aims to help the less dynamic regions (which had fallen behind either economically or in population growth), thus helping to reduce growth discrepancies among regions.

$A$ rise of the share in taxes: The shares of the regions were raised for personal income tax (from $33 \%$ to $50 \%$ ), value-added tax (from $35 \%$ to $50 \%$ ), and excise taxes (from $40 \%$ to $58 \%$ ). Of these taxes, $75 \%$ are allocated to the Fund to Guarantee Public Services and the remaining $25 \%$ are allocated to the regions where they were generated.

Source: (OECD, 2012b).

While the equalisation system reduces regional disparities on average, the system has become less effective over time (OECD, 2013). Equalisation transfers across regions are based on four different funds (Box 1.7). The horizontal equalisation mechanism, the Guarantee Fund, reduces regional dispersion in terms of financing per adjusted head, while keeping the initial ordering of the regions. Vertical transfers, via three funds of Sufficiency, Cooperation and Competitiveness, are distributed after and are based on a large number of criteria, which can be conflicting (De La Fuente, Thöne and Kastrop, 2016). They increase dispersion of revenues per head across regions compared to the post-horizontal fund distribution and lead to a ranking that is uncorrelated with the initial ranking of regions according to their tax capacity (Figure ). 
Figure 31. Vertical transfers increase dispersion of regional resources

Resources per adjusted population at different stages in the implementation of the financing system, 2015

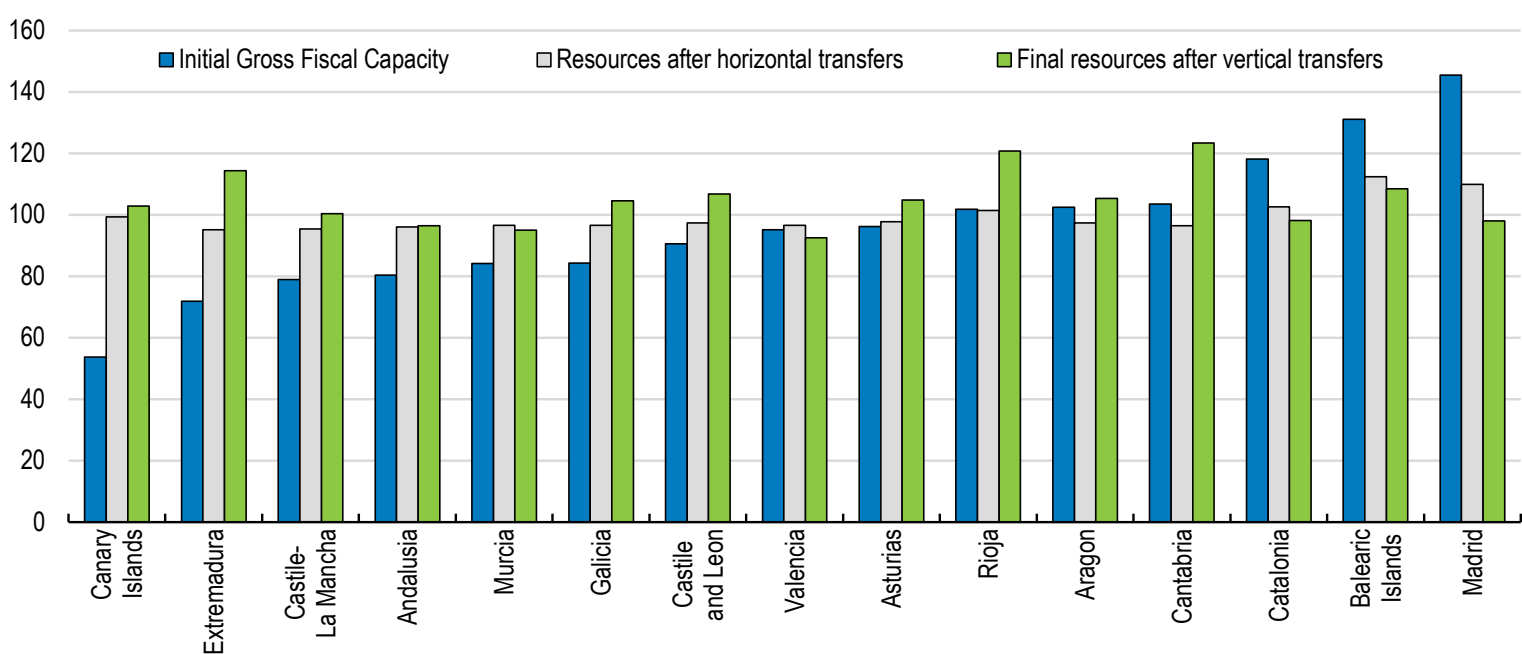

Source: De la Fuente (2013), updated with data for 2015 from de la Fuente (2017).

The reform of the regional financing system is currently under discussion. An Experts Committee released a report in July 2017, which proposes to maintain the horizontal equalisation fund, but to modify the vertical levelling funds to reduce regional revenue dispersion and decrease the number of funds. Currently, a number of committees are working on a proposal, which will then have to be submitted for agreement at the political level.

The design of a well-functioning regional financing system is difficult as different criteria can have trade-offs. However, increasing the transparency of and simplifying the system could have the dual outcome of achieving an efficient system, which is also politically feasible. Specifically, the system could be simplified by lowering the number of fiscal interregional equalisation funds and streamlining their objectives. Furthermore, previous reforms have been based on the premise that no regions would lose revenues relative to the status quo, which tends to reproduce existing inequalities and increase the complexity of the system (Lago-Peñas, Fernández-Leiceaga and Vaquero-García, 2017). While the noloss clause can be justified in the short-run to give regions time to adjust, it should not be permanent and a transition period of special allocations, which are progressively withdrawn, should be used.

\section{Improving fiscal rules}

Over the last fifteen years, the use of tax autonomy has varied across taxes and regions (AIReF, 2016). For example, regions have generally tended not to use their normative powers to raise personal income taxes, on average (European Commission, 2017). The financial incentives for regions to use tax power over ceded taxes they control can generally be superseded by the incentives not to increase the tax burden of their region. Indeed, regions have relied on the capital transfer tax and stamp duty to raise additional revenues rather than the personal income tax during the crisis (Ruiz Almendral, 2012). The incentives of regions to use their tax autonomy could be strengthened via improvements to the fiscal rules and framework and addressing the legacy of the crisis. 
In 2012, the Organic Law of Budgetary Stability and Financial Sustainability (LOEPSF) established fiscal rules for sub-national governments (SNG) in terms of expenditure ceilings, deficits and debt. In particular, SNGs are to achieve structurally-balanced budgets from 2020, increases in expenditures may not exceed medium-term GDP growth (calculated over ten years) and debt may not exceed 13\% of regional GDP for each region. Mechanisms enabling the central government to monitor sub-central finances and corrective and preventative measures were also introduced. The latter includes the possibility of sanctions, the automatic adjustment of regional expenditures in specific cases of non-compliance and the imposition of adjustment measures by the central government.

The legacy of the crisis is an important aspect of regional fiscal conditions. Regional debt increased substantially and according to the LOEPSF, it should fall below the $13 \%$ threshold in 2020, which is projected for only three regions (Figure ). Some regions also lost market access during the crisis and a Regional Liquidity Fund was created in 2012 to provide emergency liquidity, with some fiscal, financial and informational conditionality. In 2015, extraordinary funds were turned into a Regional Financing Fund to allow regions to benefit from the lower borrowing costs of the central government. It is important that all regions go back to market funding, which should help reduce moral hazard and increase fiscal compliance. The government recently took two initiatives in this area. First, regions which fulfil certain fiscal and financial requirements, including submitting a three year debt plan to the central government, can now go to market funding. Second, the central government and regions have agreed to refinance regions' structural short term debt to long-term.

\section{Figure 32. Regional debt indicators}

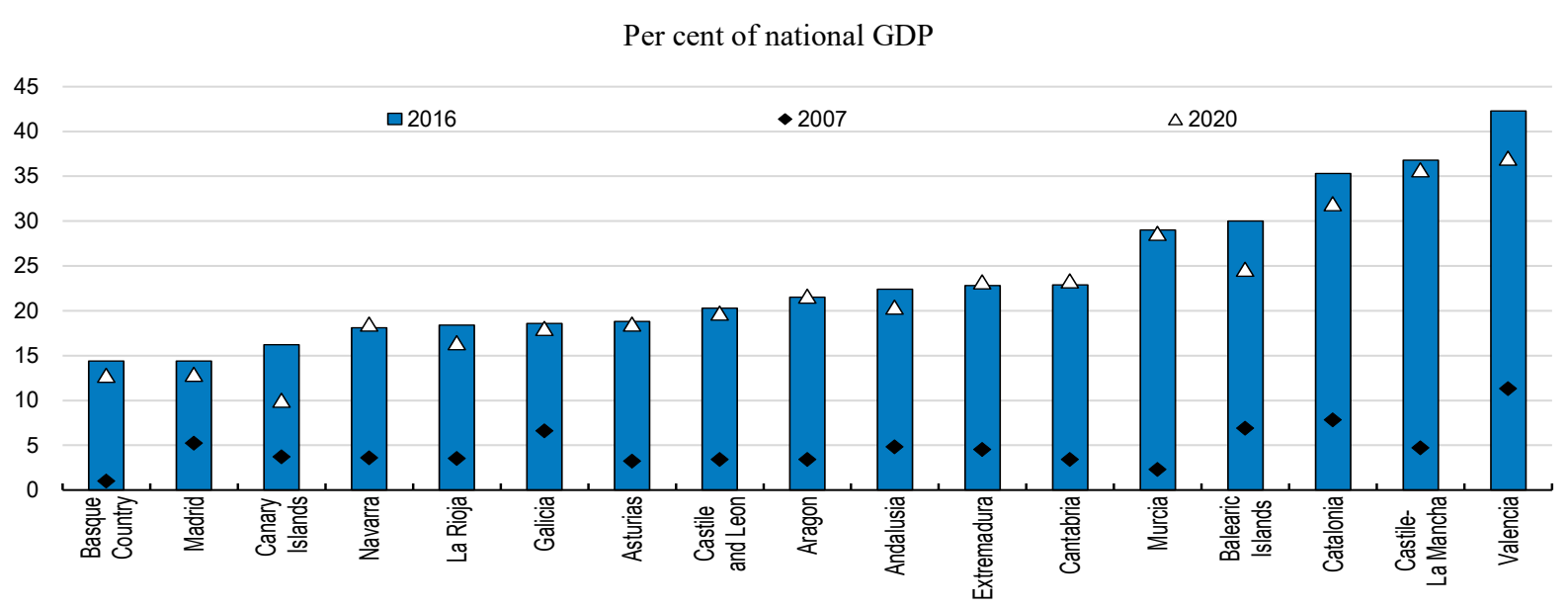

Source: AIReF (2017), Debt Monitor 2017.

The consistency of the three rules included in the LOEPSF could be strengthened to make the fiscal framework stronger. For example, having expenditure growth following GDP growth does not guarantee the return to a balanced budget in case of a deficit. Depending on the level of the deficit, the debt ratio may not return to targets, or decrease at a very slow pace. Recently, cyclical conditions have helped regions meet deficit targets, which are uniform across regions. The debt rules are designed without taking into account the initial debt level of the regions and are derived from the deficit rule. This makes the debt rule less operational and it should be reinforced with a design that can map a clear path of debt reduction to targets in the medium run. The expenditure rule should be the main tool to 
achieve the sustainability of public finances. Expenditure growth should be set to a pace which allows a regular decrease in the debt ratio towards target. For example, the expenditure rule could be made stricter by region-specific convergence margins, dependent on the gap between the current debt level and the target.

The introduction of regional fiscal rules, notably a stronger focus on the expenditure rule, should help lower the sensitivity of regional fiscal conditions to the cycle and reduce regional debt, if enforced correctly. Until recently, the use of sanctions has been rare, despite recommendations made by the Fiscal Council to the central government to apply sanctions to regions. One reason for the lack of activation of preventative measures has been the legacy of the crisis. As the economy is now in the recovery phase, it will be important to stick to medium-term fiscal targets to ensure a durable reduction of public debt at all levels of government. To help achieve this, the circumstances leading to the activation of measures to prevent non-compliance should be better defined and a pre-determined time frame (with some escape clauses) to correct non-compliance could be introduced.

\section{Box 8. Recommendations}

\section{Addressing regional disparities in labour market and education outcomes}

\section{Key recommendations}

- Increase spending on training and job-search assistance. Remove barriers to competition of training centres across regions.

- Introduce a single point of contact for social and employment services.

- Ensure full portability of social and housing benefits across regions, by providing temporary assistance either by the region of origin or the central government.

- Target existing financial incentives for lifelong learning opportunities to lowqualified workers and link them to individuals.

- Increase individualised support to students at the risk of failing at an early stage.

\section{Other recommendations}

- Lower transaction costs on buying and selling of houses to boost labour mobility.

- Regularly use means-testing to track changes in eligibility conditions in social housing.

- Link the choice of training voucher programmes to local labour market needs and provide guidance to workers through tailored guidance.

- Set minimum standards for the work-based learning part of the dual vocational education and training system across regions, while ensuring that they are designed in line with regional needs.

- Increase evaluation of schools and teachers in regions where they are rare.

- Improve incentives for the mobility of well-qualified teachers across schools and regions.

- Target training and education in digital skills to less-educated and low-income individuals, whose jobs might be more at risk of automation. 


\section{Boosting productivity and business dynamism across regions}

\section{Key recommendations}

- Regions should include the principle of national effectiveness of the Market Unity Law in their legislation. Assess the compliance of new legislation at all levels of government with the principles of the Market Unity Law.

- Give the recently activated R\&D Public Policy Network a strong mandate to further increase coordination of regional and national innovation policies.

- Strengthen ex-post evaluation framework of innovation support and consider increasing performance based funding.

\section{Other recommendations}

- Increase public awareness of the Market Unity Law through information campaigns.

- Encourage employers to adopt high performance workplace practices to improve skill use at work, for example through business coaching programmes.

\section{Getting the most out of decentralisation}

\section{Key recommendation}

- Make the expenditure rule the main rule and link it to the debt ratio targets.

\section{Other recommendations}

- Enhance cooperation and coordination across regions and between regions and the central government.

- Consider the creation of a National Evaluation Agency to evaluate policies at the regional level regularly. Make greater use of benchmarking to better identify best practices.

- Simplify the regional financing system by lowering the number of fiscal interregional equalisation funds and streamlining their objectives.

- Use a transition period of special allocations to give regions which might lose revenues time to adjust to the reform of the regional financing system.

- Better define the activation of measures to prevent non-compliance with fiscal rules. Consider introducing a pre-determined time frame (with some escape clauses) to correct non-compliance. 


\section{References}

Adalet McGowan, M. and D. Andrews (2015), "Skill Mismatch and Public Policy in OECD Countries", OECD Economics Department Working Papers, No. 1210, OECD Publishing, Paris, http://dx.doi.org/10.1787/5js1pzw9lnwk-en.

Adalet McGowan, M., D. Andrews and V. Millot (2017), "Insolvency regimes, zombie firms and capital reallocation”, OECD Economics Department Working Papers, No. 1399, OECD Publishing, Paris, http://dx.doi.org/10.1787/5a16beda-en.

Adalet McGowan, M. and J. Antona San Millán (2018), "Resource Misallocation in Spain”, mimeo.

AIReF (2016), Informe sobre el establecimiento de los objetivos individuales de estabilidad presupuestaria y deuda pública para las Comunidades Autónomas, Madrid.

Akcigit, U., D. Hanley and N. Serrano-Velarde (2013), "Back to Basics: Basic Research Spillovers, Innovation Policy and Growth", NBER Working Papers, No. 197473.

Andrews, D., A. Caldera Sánchez and Å. Johansson (2011), "Housing Markets and Structural Policies in OECD Countries", OECD Economics Department Working Papers, No. 836, OECD Publishing, Paris, http://dx.doi.org/10.1787/5kgk8t2k9vf3-en.

Andrews, D. and C. Criscuolo (2013), "Knowledge-Based Capital, Innovation and Resource Allocation", OECD Economics Department Working Papers, No. 1046, OECD Publishing, Paris, http://dx.doi.org/10.1787/5k46bj546kzs-en.

Andrews, D., C. Criscuolo and P. Gal (2016), "The Best versus the Rest: The Global Productivity Slowdown, Divergence across Firms and the Role of Public Policy", OECD Productivity Working Papers, No. 5, OECD Publishing, Paris, http://dx.doi.org/10.1787/63629cc9-en.

Andrews, D., C. Criscuolo and P. Gal (2015), "Frontier Firms, Technology Diffusion and Public Policy: Micro Evidence from OECD Countries", OECD Productivity Working Papers, No. 2, OECD Publishing, Paris, http://dx.doi.org/10.1787/5jrq12q2jij7b-en.

Andrews, D., G. Nicoletti and C. Timiliotis (2018), "Digital technology diffusion: A matter of capabilities, incentives or both?", OECD Economics Department Working Papers, No. 1476, OECD Publishing, Paris, http://dx.doi.org/10.1787/7c542c16-en.

Badillo, E. and R. Moreno (2014a), "Are R\&D collaborative agreements persistent at the firm level? Empirical evidence for the Spanish case", Research Institute of Applied Economics Working Papers, No. 10. 
Badillo, E. and R. Moreno (2014b), "Does absorptive capacity determine collaborative research returns to innovation? A geographical dimension", Research Institute of Applied Economics Working Papers, No.28.

Barnow, B. (2009), "Vouchers in U.S. vocational training programs: an overview of what we have learned", ZAF, Vol. 42, pp. 71-84, http://dx.doi.org/10.1007/s12651-009-0007-9.

Benseman, J., A. Sutton and J. Lander (2005), Working in the light of evidence, as well as commitment. A literature review of the best available evidence about effective adult literacy, numeracy and language teaching.

Berger, T. and C. Frey (2016), "Structural Transformation in the OECD: Digitalisation, Deindustrialisation and the Future of Work", OECD Social, Employment and Migration Working Papers, No. 193, OECD Publishing, Paris, http://dx.doi.org/10.1787/5jlr068802f7-en.

Blöchliger, H., D. Bartolini and S. Stossberg (2016), "Does Fiscal Decentralisation Foster Regional Convergence?", OECD Economic Policy Papers, No. 17, OECD Publishing, Paris, http://dx.doi.org/10.1787/5jlr3c1vcqmr-en.

Caldera Sánchez, A. and D. Andrews (2011), "Residential Mobility and Public Policy in OECD Countries", OECD Journal: Economic Studies, Vol. 2011/1, http://dx.doi.org/10.1787/eco_studies2011-5kg0vswqt240.

Calero, J. and J. Escardibul (2015), Reflexiones Sobre el Sistema Educativo Español, mimeo, http://sgfm.elcorteingles.es/SGFM/FRA/recursos/doc/Monografias/Educacion/58101378_13201716 363.pdf.

Calvino, F. and C. Criscuolo (2018), "Business Dynamics and Digitalisation: A Progress Report", OECD Science, Technology and Industry Working Papers, forthcoming.

Cámara, N. and J. Ruiz Sánchez (2017), BBVA-DiGiX Comunidades Autónomas: digitalización desde un enfoque regional, https://www.bbvaresearch.com/wp-content/uploads/2017/06/BBVA-DiGiXCCAA.pdf.

CEDEFOP (2015), Spain: Forecast highlights up to 2025, http://www.cedefop.europa.eu/printpdf/publications-and-resources/country-reports/spain-skillsforecasts-2025.

Chlon-Dominczak, A. and M. Lis (2013), "Does gender matter for lifelong learning activity?”, IBS Working Paper, No. 3.

Cruz-Castro, L. et al. (2018), "Economic crisis and company R\&D in Spain: do regional and policy factors matter?", Industry and Innovation, Vol. 25/8, pp. 729-751, http://dx.doi.org/10.1080/13662716.2017.1355231.

D’Agostino, L. and R. Moreno (2017), "Exploration during turbulent times: an analysis of the relation between cooperation in innovation activities and radical innovation performance during the economic crisis", Industrial and Corporate Change, Volume 27, Issue 2, http://dx.doi.org/10.1093/icc/dtx035. 
Dauth, W. et al. (2017), "German Robots - The Impact of Industrial Robots on Workers", CEPR Working Papers, No. 12306.

De La Fuente, A., M. Thöne and C. Kastrop (2016), "Regional Financing in Germany and Spain: Comparative Reform Perspectives", Barcelona GSE Working Papers, No. 884.

De La Rica, S. and R. Gorjón (2017), "Assessing the Impact of a Minimum Income Scheme in the Basque Country", IZA Discussion Papers, No. 10867.

De Roca, J. and D. La Puga (2017), "Learning by Working in Big Cities", Review of Economic Studies, Vol. 84, pp. 106-142, http://dx.doi.org/10.1093/restud/rdw031.

ERAC (2014), ERAC Peer Review of the Spanish Research and Innovation System Final report, Brussels.

European Commission (2017), Country Report: Spain 2017, Brussels.

European Commission (2015), Adult Education and Training in Europe: Widening Access to Learning Opportunities, Brussels.

Felgueroso, F. (2017), Lifelong learning in Spain: a challenge for the future, FEDEA, http://www.fedea.net/nsaw/descargas/NSAW02en.pdf.

Fernandez, R. et al. (2018), "Faces of Joblessness in Spain: A People-centred perspective on employment barriers and policies", OECD Social, Employment and Migration Working Papers, No. 207, OECD Publishing, Paris, http://dx.doi.org/10.1787/6149118d-en.

Fernandez-Zubieta, A., I. Ramos-Vielba and T. Zacharewicz (2018), RIO Country Report: Spain. 2017.

Fritsch, M. (2008), "How does new business formation affect regional development? Introduction to the special issue", Small Business Economics, Vol. 30/1, http://dx.doi.org/10.1007/s11187-0079057-y.

Gamberoni, E., C. Giordano and P. Lopez-Garcia (2016), "Capital and labour (mis)allocation in the euro area: some stylized facts and determinants", ECB Working Paper Series, No. 1981, http://dx.doi.org/10.2866/726549.

García Pérez, J. (2017), "Una primera evaluación del impacto sobre la salida del desempleo de las políticas activas ofrecidas por los servicios públicos de empleo en España”, Fedea Policy Papers, No. 7.

García-Posada, M. and J. Mora-Sanguinetti (2015), "Entrepreneurship and enforcement institutions: disaggregated evidence for Spain", European Journal of Law and Economics, Vol. 40/1, https://doi.org/10.1007/s10657-014-9470-z.

García-Santana, M. et al. (2016), “Growing like Spain: 1995-2007”, Bank of Spain Working Papers, No. 1609. 
Gopinath, G. et al. (2017), "Capital Allocation and Productivity in South Europe", The Quarterly Journal of Economics, Vol. 132/4, pp. 1915-1967, http://dx.doi.org/10.1093/qje/qjx024.

Government of Spain (2018), Programa Nacional de Reformas de España 2018, Madrid.

Izquierdo, M. et al. (2005), "Heterogeneidad en los mercados de trabajo regionales", Boletín Económico OCT.

Jimeno, J. and S. Bentolila (1998), "Regional unemployment persistence: Spain, 1976-1994”, Labour Economics, Vol. 5, pp. 25-52, https://doi.org/10.1016/S0927-5371(96)00019-X.

Kerimoglu, E. and B. Karahasan (2011), "Geography of talent and regional differences in Spain", Research Institute of Applied Economics Working Papers, No. 7.

Kierzenkowski, R., P. Gal and G. Fulop (2017), "Where to get the best bang for the buck in the United Kingdom?: Industrial strategy, investment and lagging regions", OECD Economics Department Working Papers, No. 1426, OECD Publishing, Paris, http://dx.doi.org/10.1787/2d01150c-en.

Lago-Peñas, S., X. Fernández-Leiceaga and A. Vaquero-García (2017), "Spanish fiscal decentralization: A successful (but still unfinished) process", Environment and Planning: Politics and Space, Vol. 35/8, pp. 1509-1525, http://dx.doi.org/10.1177/2399654417704663.

Law, D. (2018), "Productivity Convergence in Spain", OECD Economics Department Working Papers, forthcoming.

Lind, H. (2001), "Rent Regulation: A Conceptual and Comparative Analysis", International Journal of Housing Policy, Vol. 1/1, http://dx.doi.org/10.1080/14616710110036436.

López-Bazo, E. and E. Motellón (2013a), "Firm exports, innovation and regions", Research Institute of Applied Economics Working Papers, No. 8.

López-Bazo, E. and E. Motellón (2013b), "Innovation, heterogeneous firms and the regions", Research Institute of Applied Economics Working Papers, No. 7.

Mas, M., F. Pérez and J. Quesada (2009), "The Sources of Spanish Regional Growth", in Regional Policy, Economic Growth and Convergence, Springer Berlin Heidelberg, Berlin, Heidelberg, http://dx.doi.org/10.1007/978-3-642-02178-7_6.

Ministry of Employment (2016), Encuesta Anual Laboral 2016, Madrid.

Nedelkoska, L. and G. Quintini (2018), “Automation, skills use and training”, OECD Social, Employment and Migration Working Papers, No. 202, OECD Publishing, Paris, http://dx.doi.org/10.1787/2e2f4eea-en.

OECD (2018a), Productivity and Jobs in a Globalised World: How Can all Regions Benefit?, OECD Publishing, Paris, https://doi.org/10.1787/9789264293137-en.

OECD (2018b), Getting Skills Right: Spain, OECD Publishing, Paris, https://doi.org/10.1787/9789264282346-en. 
OECD (2018c), Teachers in Ibero-America: Insights form PISA and TALIS, OECD Publishing, Paris, http://www.oecd.org/pisa/Teachers-in-Ibero-America-Insights-from-PISA-and-TALIS.pdf.

OECD (2018d), Effective Teacher Policies: Insights from PISA, OECD Publishing, Paris, http://dx.doi.org/10.1787/9789264301603-en.

OECD (2018e), Making Decentralisation Work: a Handbook for Policy-Makers, OECD publishing, Paris.

OECD (2017a), How's Life in Spain, OECD Publishing, Paris, https://www.oecd.org/statistics/BetterLife-Initiative-country-note-Spain.pdf.

OECD (2017b), The Geography of Firm Dynamics: Measuring Business Demography for Regional Development, OECD Publishing, Paris, http://dx.doi.org/10.1787/9789264286764-en.

OECD (2017c), OECD Economic Surveys: Spain 2017, OECD Publishing, Paris, http://dx.doi.org/10.1787/eco_surveys-esp-2017-en.

OECD (2017d), "How to make trade work for all", in OECD Economic Outlook, Volume 2017 Issue 1, OECD Publishing, Paris, http://dx.doi.org/10.1787/eco_outlook-v2017-1-3-en.

OECD (2017e), Financial Incentives for Steering Education and Training, Getting Skills Right, OECD Publishing, Paris, http://dx.doi.org/10.1787/9789264272415-en.

OECD (2017f), Going Digital: Making the Transformation Work for Growth and Well-Being, https://www.oecd.org/mcm/documents/C-MIN-2017-4\%20EN.pdf.

OECD (2017g), OECD Science, Technology and Industry Scoreboard 2017: The digital transformation, OECD Publishing, Paris, http://dx.doi.org/10.1787/9789264268821-en.

OECD (2017h), "Making policy evaluation work: The case of regional development policy", OECD Science, Technology and Industry Policy Papers, No. 38, OECD Publishing, Paris, http://dx.doi.org/10.1787/c9bb055f-en.

OECD (2017i), OECD Multi-level Governance Studies: Multi-level Governance Reforms, OECD Publishing, Paris https://doi.org/10.1787/9789264272866-en.

OECD (2017j), Effective Public Investment Toolkit, https://www.oecd.org/effective-public-investmenttoolkit/.

OECD (2016a), Job Creation and Local Economic Development 2016, OECD Publishing, Paris, https://doi.org/10.1787/9789264261976-en.

OECD (2016b), OECD Regions at a Glance 2016, OECD Publishing, Paris, http://dx.doi.org/10.1787/reg_glance-2016-en.

OECD (2016c), OECD Regional Outlook 2016: Productive Regions for Inclusive Societies, OECD Publishing, Paris, http://dx.doi.org/10.1787/9789264260245-en. 
OECD (2016d), PISA 2015 Results (Volume II): Policies and Practices for Successful Schools, OECD Publishing, Paris, http://dx.doi.org/10.1787/9789264267510-en.

OECD (2016e), OECD Employment Outlook 2016, OECD Publishing, Paris, http://dx.doi.org/10.1787/empl_outlook-2016-en.

OECD (2016f), "Stimulating digital innovation for growth and inclusiveness: The role of policies for the successful diffusion of ICT", OECD Digital Economy Papers, No. 256, OECD Publishing, Paris, http://dx.doi.org/10.1787/5jlwqvhg3131-en.

OECD (2016g), Fiscal Federalism 2016: Making Decentralisation Work, OECD Publishing, Paris, http://dx.doi.org/10.1787/9789264254053-en.

OECD (2016h), OECD Public Governance Reviews: Spain 2016: Linking Reform to Results for the Country and its Regions, OECD Publishing, Paris, http://dx.doi.org/10.1787/9789264263024-en.

OECD (2015), The Future of Productivity, OECD Publishing, Paris, http://dx.doi.org/10.1787/9789264248533-en.

OECD (2014), How's Life in Your Region?: Measuring Regional and Local Well-being for Policy Making, OECD Publishing, Paris, http://dx.doi.org/10.1787/9789264217416-en.

OECD (2013), Fiscal Federalism 2014: Making Decentralisation Work, OECD Publishing, Paris, http://dx.doi.org/10.1787/9789264204577-en.

OECD (2012a), Equity and Quality in Education: Supporting Disadvantaged Students and Schools, OECD Publishing, Paris, http://dx.doi.org/10.1787/9789264130852-en.

OECD (2012b), OECD Fiscal Federalism Studies: Reforming Fiscal Federalism and Local Government, OECD Publishing, Paris, https://doi.org/10.1787/9789264119970-en.

OECD (2009), How Regions Grow: Trends and Analysis, OECD Publishing, Paris, http://dx.doi.org/10.1787/9789264039469-en.

Oesch, D. and J. Rodriguez Menes (2011), "Upgrading or polarization? Occupational change in Britain, Germany, Spain and Switzerland, 1990-2008”, Socio-Economic Review, Vol. 9/3, pp. 503531, http://dx.doi.org/10.1093/ser/mwq029.

Oswald, A. (1999), The Housing Market and Europe's Unemployment: A Non-Technical Paper, https://warwick.ac.uk/fac/soc/economics/staff/ajoswald/homesnt.pdf.

Palomares-Linares, I. and M. Van Ham (2016), "Understanding the Effects of Homeownership and Regional Unemployment Levels on Migration during the Economic Crisis in Spain", IZA Discussion Papers, No. 10232.

Phillips, L. (2018), "Improving the Performance of Sub-national Governments through Benchmarking and Performance Reporting", OECD Working Papers on Fiscal Federalism, No. 22, OECD Publishing, Paris, http://dx.doi.org/10.1787/ffff92c6-en.

Puente, S. (2017), “Regional Convergence in Spain: 1980-2015”, Economic Bulletin, Vol. 3. 
Rubenson, K. and R. Desjardins (2009), "The Impact of Welfare State Regimes on Barriers to Participation in Adult Education A Bounded Agency Model", Adult Education Quarterly, Vol. 59/3, pp. 187-207, http://dx.doi.org/10.1177/0741713609331548.

Ruiz Almendral, V. (2012), "Sharing Taxes and Sharing the Deficit in Spanish Fiscal Federalism", eJournal of Tax Research, Vol. 10/1.

Saia, A., D. Andrews and S. Albrizio (2015), "Productivity Spillovers from the Global Frontier and Public Policy: Industry-Level Evidence", OECD Economics Department Working Papers, No. 1238, OECD Publishing, Paris, http://dx.doi.org/10.1787/5js03hkvxhmr-en.

Salvi del Pero, A. et al. (2016), "Policies to promote access to good-quality affordable housing in OECD countries", OECD Social, Employment and Migration Working Papers, No. 176, OECD Publishing, Paris, http://dx.doi.org/10.1787/5jm3p5gl4djd-en.

Secretaría del Consejo para la Unidad de Mercado (2017), Catalago de Buenas y Malas Practicas en la Aplicacion de la Rey 20/2013, Madrid.

Siedschlag, I., M. Lawless and M. Ubaldo (2017), Investment in Knowledge-Based Capital and its Contribution to Productivity Growth, https://www.esri.ie/pubs/BKMNEXT336.pdf.

Sims, D. (2007), "Out of control: What can we learn from the end of Massachusetts rent control?", Journal of Urban Economics, Vol. 61, pp. 129-151, http://dx.doi.org/10.1016/j.jue.2006.06.004.

Välijärvi, J. and P. Sahlberg (2008), "Should 'failing' students repeat a grade? Retrospective response from Finland”, Journal of Educational Change, http://dx.doi.org/10.1007/s10833-008-9089-3.

van der Vilst, A. et al. (2002), "Residential mobility and local housing-market differences", Environment and Planning, Vol. 34, http://dx.doi.org/10.1068/a34176.

Van Ommeren, J. and M. Van Leuvensteijn (2005), "New Evidence of the Effect of Transaction Costs on Residential Mobility", Journal of Regional Science, Vol. 45/4, pp. 681-702, http://dx.doi.org/10.1111/j.0022-4146.2005.00389.x. 